RELF Group \& OEAPS Inc.

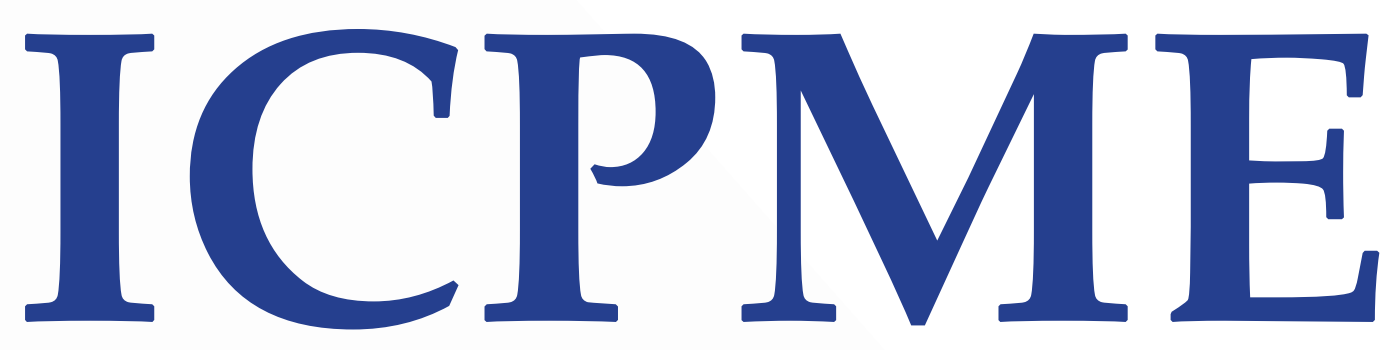

International Scientific

and Practical Conference

PEDAGOGY AND

MODERN EDUCATION

September 2019

Warsaw, Poland 
Conference paper Covered by Leading Indexing Databases

Open European Academy of Public Sciences aims to have all of its journals covered by the Science Citation Index Expanded (SCIE) and Scopus and Web of Science indexing systems. Several journals have already been covered by SCIE for several years and have received official Impact Factors. Some life science related journals are also covered by PubMed/MEDLINE and archived through PubMed Central (PMC). All of our journals are archived with the Spanish and Germany National Library.

All Content is Open Access and Free for Readers Journals published by Open European Academy of Public Sciences are fully open access: research articles, reviews or any other content on this platform is available to everyone free of charge. To be able to provide open access journals, we finance publication through article processing charges (APC); these are usually covered by the authors' institutes or research funding bodies. We offer access to science and the latest research to readers for free. All of our content is published in open access and distributed under a Creative Commons License, which means published articles can be freely shared and the content reused, upon proper attribution.

Open European Academy of Public Sciences Publication Ethics Statement Open European Academy of Public Sciences is a member of the Committee on Publication Ethics (COPE). Open European Academy of Public Sciences takes the responsibility to enforce a rigorous peerreview together with strict ethical policies and standards to ensure to add high quality scientific works to the field of scholarly publication. Unfortunately, cases of plagiarism, data falsification, inappropriate authorship credit, and the like, do arise. Open European Academy of Public Sciences takes such publishing ethics issues very seriously and our editors are trained to proceed in such cases with a zero tolerance policy. To verify the originality of content submitted to our journals, we use iThenticate to check submissions against previous publications.

Mission and Values

As a pioneer of academic open access publishing, we serve the scientific community since 2009. Our aim is to foster scientific exchange in all forms, across all disciplines. In addition to being at the root of Open European Academy of Public Sciences and a key theme in our journals, we support sustainability by ensuring the longterm preservation of published papers, and the future of science through partnerships, sponsorships and awards.

(C) 2019 The Author. Published by ISA \& OEAPS EU Inc. This is an open access article under the CC BY-NC-ND license (http://creativecommons.org/licenses/by-nc-nd/4.0/). 
OEAPS is am inprint of RELF Group \& OEAPS INC.

Gran Via de les Corts Catalanes, 585, 08007 Barcelona, SP

Unter den Linden, 4, 10099 Berlin, DE

245 Peachtree Center Avenue, Suite 1900. Atlanta, GA 30303, USA

Copyright (c) 2019 RELF Group \& OEAPS Inc. All rights reserved.

This journal and the individual contributions contained in it are protected under copyright by Open European

Academy of Public Sciences, and the following terms and conditions apply to their use:

Photocopying

Single photocopies of single articles may be made for personal use as allowed by national copyright laws. Permission

of the Publisher and payment of a fee is required for all other photocopying, including multiple or systematic copying, copying for advertising or promotional purposes, resale, and all forms of document delivery. Special rates are available for educational institutions that wish to make photocopies for non-profi t educational classroom use. For information on how to seek permission visit https://academy.scopuseu.com/

Derivative Works

Subscribers may reproduce tables of contents or prepare lists of articles including abstracts for internal circulation within their institutions. Permission of the Publisher is required for resale or distribution outside the institution.

Permission of the Publisher is required for all other derivative works, including compilations and translations (please consult https://academy.scopuseu.com/).

Electronic Storage or Usage

Permission of the Publisher is required to store or use electronically any material contained in this journal, including any article or part of an article (please consult https://academy.scopuseu.com/).

Except as outlined above, no part of this publication may be reproduced, stored in a retrieval system or transmitted in any form or by any means, electronic, mechanical, photocopying, recording or otherwise, without prior written permission of the Publisher.

Notice

No responsibility is assumed by the Publisher for any injury and/or damage to persons or property as a matter of products liability, negligence or otherwise, or from any use or operation of any methods, products, instructions or ideas contained in the material herein. Because of rapid advances in the medical sciences, in particular, independent verifi cation of diagnoses and drug dosages should be made. Although all advertising material is expected to conform to ethical (medical) standards, inclusion in this publication does not constitute a guarantee or endorsement of the quality or value of such product or of the claims made of it by its manufacturer.

Funding body agreements and policies

OEAPS Inc. has established agreements and developed policies to allow authors whose articles appear in journals published by ISA\&OEAPS Inc., to comply with potential manuscript archiving requirements as specifi ed as conditions of their grant awards. To learn more about existing agreements and policies please visit https://academy. scopuseu.com/

Publication information: «PEDAGOGY AND MODERN EDUCATION» September, (2019). (ISBN: 9781697070392). For 2019, September issues is scheduled for publication. Subscription prices are available upon request from the Publisher or from the ISA\&OEAPS Inc. Customer Service Department nearest you or from this journal's website (http://scopuseu.com/scopus/index.php/pme/index).

Further information is available on this journal and other RELF Group\&OEAPS Inc. products through OEAPS website (https://academy.scopuseu.com). Subscriptions are accepted on a prepaid basis only and are entered on a calendar year basis. Issues are sent by standard mail (surface within Europe, air delivery outside Europe). Priority rates are available upon request. Claims for missing issues should be made within six months of the date of dispatch. Orders, claims, and journal enquiries: Please visit our Support Hub pagehttps://academy.scopuseu.com for assistance. Author inquiries: You can track your submitted article at https://academy.scopuseu.com. You can track your accepted article at https://academy.scopuseu.com.

You are also welcome to contact Customer Support via https://academy.scopuseu.com Advertising information: If you are interested in advertising or other commercial opportunities please e-mail: office@ scopuseu.com and your enquiry will be passed to the correct person. Á who will respond to you within 48 hours. Printed in the Germany 
Approved at the meeting of the editorial board

PEDAGOGY AND MODERN EDUCATION (ICPME) September 2019: сб.науч.тр./

RELF Group \& OEAPS Inc.; редкол.: Каапо Кумпулайнен (отв.ред.) [и др.]. - Варшава, Польша : OEAPS Inc., 09. 2019. - 114 C.

Number layout 26.09.2019

Signed in print 28.09..2019

Published on 02.10.2019 


\title{
Editor-in-Chief
}

K. Kumpulainen

University of Helsinki, Helsinki, Finland

\section{International Editorial Board}

\author{
N. Beckmann
}

Durham University, Durham, UK

T. H. Chiang

Zhengzhou University, Zhengzhou, Henan, China

B. Csapo

University of Szeged, Szeged, Hungary

M. de Haan

Universiteit Utrecht, Utrecht, Netherlands

L. Dunne

Queen's University Belfast, Belfast, Northern Ireland, UK

R. Gillies

University of Queensland, Brisbane, Queensland, Australia

H. Goldstein

University of Bristol, Bristol, UK

E. Hall

Newcastle University, Newcastle, UK

S. Hennessy

University of Cambridge, Cambridge, UK

E.K. Hyry-Beihammer

University of Education Upper Austria, Linz, Austria

D. Jones

Sam Houston State University, Huntsville, Texas, USA

S. Miller

Queen's University Belfast, Belfast, Northern Ireland, UK

C. Robinson

University of Brighton, Brighton, UK

S. Rojas-Drummond

Universidad Nacional Autónoma de México (UNAM), Delegación Coyoacán, Mexico

C.J. Roseth

Michigan State University, East Lansing, Michigan, USA

R. Säljö

Göteborgs Universitet, Molndal, Sweden

D. Sears

Purdue University, West Lafayette, Indiana, USA 
(C) 2019 The Author. Published by ISA \& OEAPS EU Inc. This is an open access article under the CC BY-NC-ND license (http://creativecommons.org/licenses/by-nc-nd/4.0/). 


\section{Contents}

Гульдар Фанисовна Ибрагимова 9 9-16

Олимпиада по русскому языку как средство формирования языковой личности

Ольга Алексеевна Ковалевич

Невербальные средства общения в работе педагога

17-22

Раиса Николаевна Афонина

Принцип гуманитаризации в содержании и методике естественнонаучной подготовки будущего учителя гуманитарного профиля

Раиса Николаевна Афонина, Елена Алексеевна Лесных

Теоретические аспекты гуманитаризации и гуманизации образовательного

процесса

Яна Игоревна Ряполова, Павел Иванович Образцов

Моделирование процесса профессиональной адаптации будущих педагогов

$35-44$

специального образования на младших курсах обучения в вузе

Алина Владимировна Стадник

Алкоголь и подростки. Профилактика пьянства и алкоголизма среди молодёжи

\section{Виктория Викторовна Гарифуллина}

Возможности школьного музея в формировании гражданственности и граж-

данской активности школьников

Людмила Константиновна Синцова

66-75

Патриотизм: осмысление исторических традиций воспитания

Cezary Szpytma, Magdalena Szpytma

76-92

Model of 21st Century Physical Learning Environment (MoPLE21)

Галина Ивановна Дерябина, Артем Валентинович Савельев,

93-106

Виктория Леонидовна Лернер, Людмила Николаевна Макарова

Динамика показателей видов координационных способностей в процессе их развития средствами карате у детей младшего школьного возраста с нарушением слуха

Ольга Юрьена Муллер

107-112

Инклюзивное сопровождение и социальная адаптация студентов с нарушениями слуха 

International Scientific and Practical Conference

PEDAGOGY AND MODERN EDUCATION

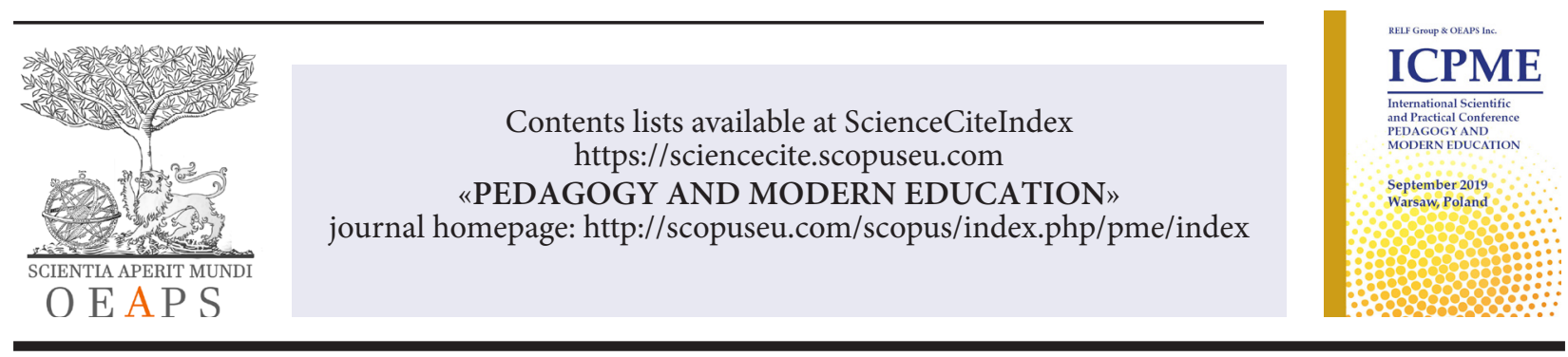

УДК 379.8

Олимпиада по русскому языку как средство формирования языковой личности

Ибрагимова Гульдар Фанисовна

Бамкирский государственный педагогический университет им. М. Акмулль, ассистент кафедры теорий и методик начального образования,

Россия, город Уфа

guldar.ibragimowa2017@yandex.ru

Гайсина Айгуль Ирековна

учитель начальных классов школа № 3,

Россия, Республика Башкортостан,село Инзер

\begin{abstract}
Russian language olympiad as a means of forming a linguistic personality
Ibragimova Guldar Fanisovna

Bashkir State Pedagogical University named after M. Akmullah, Assistant, Department of Theories and Methods of Primary Education, Russia, Ufa guldaribragimowa2017@yandex.ru

Gaysina Aigul Irekovna primary school teacher school number 3, Russia, Republic of Bashkortostan, Inzer village
\end{abstract}

(C) 2019 The Author. Published by OEAPS Inc. This is an open access article under the CC BY-NC-ND license (http://creativecommons.org/licenses/by-nc-nd/4.0/) 
Аннотация: статья раскрывает основные аспекты формирования языковой личности, в том числе коммуникативных универсальных учебных действий у обучающихся третьего класса в ходе решения олимпиад по русскому языку. Базой исследования являлась МОБУ СОШ №3 с. Инзер, Белорецкий район Республики Башкортостан.

Resume: The article reveals the main aspects of the formation of a linguistic personality, including communicative universal educational actions of third-grade students in the course of solving Russian language competitions. The study was based on MOBU secondary school No. 3 pp. Inzer, Beloretsky district of the Republic of Bashkortostan.

Ключевые слова: языковая личность, коммуникативные универсальные учебные действия, внеурочная деятельность, олимпиада

Key words: linguistic personality, communicative universal educational actions, extracurricular activities, olympiad.

Обновление системы образования в Российской Федерации на современном этапе его развития актуализирует необходимость формирования языковой личности обучающихся, обладающий грамотной, выразительной речью, способного к сотрудничеству и четкому пониманию картины мира. Обеспечение качества начального общего образования подтверждается ФГОС НОО (Федеральный государственный образовательный стандарт начального общего образования). Ю.Н.Караулов определяет языковую личность как: «совокупность способностей и характеристик человека, обуславливающих создание и восприятие им речевых произведений, которые различаются степенью структурно-языковой сложности, глубиной и точностью отражения действительности, определенной целевой направленностью»[2].

Анализ психолого-педагогической литературы показал, что в последние годы в начальном общем образовании вырос интерес к изучению языковой личности, однако недостаточно проработаны определенные условия для её становления в полной мере. Организация олимпиады является одним из продуктивных средств не только по выявлению одарённых детей, но и способствует формированию языковой личности младшего школьника, в том числе коммуникативных универсальных учебных действий [3].

Отметим, что Г.А. Асмолов выделяет следующие коммуникативные универсальные учебные действия, которые встречаются при решении олимпиады:

- понимание возможности различных точек зрения, не совпадающих с собственной;

- готовность к обсуждению различных точек зрения и выработке общей (групповой) позиции;

- умение устанавливать и сравнивать разные точки зрения, прежде чем принимать решение и делать выбор;

- умение аргументировать свою точку зрения 
- планирование общих способов работы;

- обмен знаниями между членами группы для принятия эффективных совместных решений;

- способность с помощью вопросов добывать недостающую информацию (познавательная инициативность);

- использование адекватных языковых средств для отображения в форме речевых высказываний своих чувств, мыслей, побуждений и иных составляющих внутреннего мира; - речевое отображение (описание, объяснение) учеником содержания совершаемых действий в форме речевых значений с целью ориентировки (планирование, контроль, оценка) в предметно-практической или иной деятельности как в форме громкой социализированной речи, так и в форме внутренней речи (внутреннего говорения)

- процесса переноса во внутренний план в ходе усвоения новых умственных действий и понятий.

Исходя из вышесказанного, определяются противоречия:

- между возросшей потребностью современного общества в качественной подготовке обучающихся к олимпиадепо русскому языку, и недостаточным обеспечением педагогических условий в начальном общем образовании по формированию языковой личности; 2) между необходимостью создания научно-обоснованной методики, и недостаточностью разработанностью данного вопроса в этом направлении; 3) между объективной потребностью в разработке методических рекомендаций по организации олимпиады по русскому языку с младшими школьниками и неполной разработанностью теоретико-методических аспектов.

Основываясь на выдвинутых противоречиях, проблеме, задачах, цели исследования была проведена опытно-педагогическая работа экспериментального характера.

Базой исследования по выявлению сформированности коммуникативных УУд являлась МОБУ СОШ №3 с. Инзер, Белорецкий район Республики Башкортостан, 3 «А» класс. В ходе опытно-педагогической работы экспериментального характера были использованы методики Г.А. Цукерман («Руковички», «Ковёр», «Кто прав?»), реализовывалась программа внеурочной деятельности общеинтеллектуального направления «Для тех, кто любит русский язык», проводилась олимпиада различных уровней.

Входная олимпиада по русскому языку состояла из базовой части заданий на выявления грамотности, знания написания слов, применения орфограмм, умение анализировать текст с ошибками. Например:

Я шол полестной дарошке в диревну. Месносьть была мене знакома. В чяше леса слышался галасок малинофки.

У апушки милкали голубые колоколчики и белые рамашки на высокой ношке. Ат апушки к диревне тенулась паляна. За паляной сенела речька. 
Далее была проведена промежуточная олимпиада. Детям также была предложена разноуровневая система оценивания. В данную олимпиаду были включены задания на умение проставлять ударение, находить корень в слове, знать что такое словосочетание и т.д. Например, для базового уровня было предложено такое задание:

Найди и подчеркни «лишнее» слово. Выдели корень.

Тайком, тайна, тайга, тайно, тайный.

Чистка, читатель, чистота, чистый, чистюля.

В повышенный уровень вошли более усложнённый вариант:

Грамматическая арифметика.

a) до + костяные наросты на головах некоторых животных $=$ путь

б) сл + дерево $=$ фрукт

в) в + стихотворение $=$ жидкость

г) $\mathrm{c}+$ шерсть $=$ эмоция

д) $\mathrm{м}+$ животное $=$ темнота

Итоговая олимпиада по русскому языку содержала в себе и базовый уровень заданий и повышенный. Например, было дано такого типа задание:

Восемь ос.

- на этой осе в октябре позолота

- а эта растёт на лугу и болотах

oc_- a.

- у этой на лапках зелёные иглы

oc_- a.

- эта оса на луну летает

- эта на солнце худеет и тает

- эта боится горчицы и вилки

- с этою спит в колыбельке малыш

- эта по классу крадётся, как мышь

- oc_a.

$-\mathrm{oc}_{-}-\mathrm{a}_{-}$

$-\mathrm{OC}_{-}-\mathrm{C}_{\mathrm{a}}$

${ }_{-} \mathrm{oc}{ }_{-} \mathrm{c}_{-} \mathrm{a}$

- oc _ a

${ }_{-} \mathrm{o}_{-} \mathrm{c}_{---{ }^{\mathrm{a}}}$

Контрольный этап опытно-педагогической работы экспериментального характера показал, что 33\% испытуемых имеют высокий уровень сформированности коммуникативных УУД, $40 \%$ - средний уровень, а $27 \%$ - низкий уровень.

Таким образом, мы пришли к выводу, что:

- основная задача российского образования состоит в организации эффективных условий для достижения обучающимися качественных образовательных результатов, универсальных учебных действий, в том числе коммуникативных, позволяющих развивать языковую личность младшего школьника, опыт самостоятельной деятельности, становление внутренней позиции;

- целостное формирование и развитие языковой личности обучающихся реализуется не только в ходе урочной деятельности, но и внеурочной, предполагающая взаимодействие внешних 
условий с внутренними процессами, проецируя подходящую «внутреннюю среду», которая содействует стремительному развитию личности младшего школьника, направленную на усовершенствование как творческих, так и интеллектуальных способностей, познавательного интереса, инициативы, любознательности;

- одним из продуктивных средств формирования языковой личности является реализация олимпиад по русскому языку, которая позволяет освоить механизм самостоятельного поиска и обработки новой информации, побуждает к развитию благоприятной атмосферы саморазвития личности, коллектива, создающее целостное открытое пространство, охватывающее как образовательное учреждение, так и соприкасающеюся с ней среду, освоенную коллективом педагогов и обучающихся.

\section{Список литературы}

1. Ибрагимова, Г.Ф. Теоретико-методологические аспекты формирования учебнопознавательной компетенции младших школьников во внеурочной общеинтеллектуальной деятельности [Текст] / В.Н. Гуров, Г.Ф. Ибрагимова // Инновации в образовании. - 2013. - № 5. - С.5-13.

2. Караулов, Ю.Н. Русский язык и языковая личность [Текст] / Ю.Н. Караулов. - М.: Издательство ЛКИ, 2010. - 427 с.

3. Москаленко, Т.Н. Организация внеурочной деятельности учащихся по русскому языку [Текст] / Т. Н. Москаленко // Практические советы учителю. - 2013. - №6. - с. 30-33.

\section{The text of the article in English}

Updating the education system in the Russian Federation at the present stage of its development actualizes the need for the formation of the linguistic identity of students with a competent, expressive speech, capable of cooperation and a clear understanding of the world picture. Quality assurance of primary general education is confirmed by the Federal State Educational Standards of Public Educational Institutions of the Russian Federation (Federal State Educational Standard for Primary General Education). Yu.N. Karaulov defines a linguistic personality as: "a set of human abilities and characteristics that determine the creation and perception of speech works that differ in the degree of structural and linguistic complexity, depth and accuracy of reflection of reality, a certain target orientation" [2].

An analysis of psychological andpedagogical literature showed that in recent yearsin primary general education, interest in the study of a linguistic personality has grown, but certain conditions for its full development have not been sufficiently developed. The organization of the Olympiad is one of the productive means not only for identifying gifted children, but also contributes to the formation of the linguistic personality of a primary school student, including communicative universal educational actions [3]. 
Note that G.A. Asmolov identifies the following communicative universal educational actions that are encountered in solving the Olympiad:

- understanding of the possibility of various points of view that do not coincide with one's own;

- willingness to discuss various points of view and develop a common (group) position;

- the ability to establish and compare different points of view before making a decision and making a choice;

- the ability to argue their point of view

- the planning of common ways of working;

- exchange of knowledge between group members to make effective joint decisions;

- the ability to use the questions to obtain the missing information (cognitive initiative);

- the use of adequate linguistic means to display in the form of verbal expressions of one's feelings, thoughts, motives and other components of the inner world;

- speech display (description, explanation) by the student of the content of the actions performed in the form of speech meanings for the purpose of orientation (planning, control, evaluation) in a subject-practical or other activity both in the form of loud socialized speech, and in the form of internal speech (internal speaking)

- the process of transferring into the internal plan during the assimilation of new mental actions and concepts.

Based on the foregoing, contradictions are identified:

- between the increased need of modern society for high-quality training of students for the Russian language Olympiad, and the insufficient provision of pedagogical conditions in primary general education for the formation of a linguistic personality; 2) between the need to create a science-based methodology, and the lack of development of this issue in this direction; 3 ) between the objective need for the development of guidelines for the organization of the Olympiad in the Russian language with younger students and the incomplete development of theoretical and methodological aspects.

Based on the contradictions put forward, the problem, tasks, and goals of the study, experimental and pedagogical work of an experimental nature was carried out.

The base of the study to identify the formation of communicative UUD was MOBU SOSH №3 s. Inzer, Beloretsky district of the Republic of Bashkortostan, 3 "A" class. In the course of experimental and pedagogical work of an experimental nature, G.A. Zuckerman (Rukovichki, "Carpet", "Who is right?"), A program of extracurricular activities of the general intellectual direction "For those who love Russian" was implemented, an olympiad of various levels was held.

The input olympiad in the Russian language consisted of the basic part of the tasks on literacy, knowledge of spelling, the use of spelling, the ability to analyze a text with errors. For example: I am a shole to a polestnaya daroshka in the village. Mesnost was less familiar. In the bowl of the forest, the raspberries of the raspberry were heard. 
At the apushka, blue bells and white frames on a high toe were silent. At apushki, a fire was shaded to the village. Behind the scorching senel speech.

Next was an intermediate olympiad. Children were also offered a multi-level grading system. This Olympiad included tasks on the ability to put stress, find the root in a word, know what a phrase is, etc. For example, for the basic level, the following task was suggested:

Find and underline the "extra" word. Highlight the root.

Secretly, secret, taiga, secretly, secret.

Cleaning, reader, cleanliness, clean, clean.

The more sophisticated version includes a more complicated version:

Grammatical arithmetic.

a) to + bone growths on the heads of some animals $=$ path

b) $\mathrm{c}+$ tree $=$ fruit

c) $\mathrm{c}+$ poem $=$ liquid

d) $\mathrm{c}+$ wool $=$ emotion

e) $\mathrm{m}+$ animal $=$ darkness The

final Russian language competition contained in itself and the basic level of tasks and increased. For example, this type of task was given:

Eight wasps.

- on this wasp in October gilding os _ a.

- and this grows in a meadow and swamps os _

- this one has green needles _ wasps _ on its legs.

- this wasp flies to the moon _ wasp _ _ $\mathrm{a}_{-}$

- this one is losing weight and melting in the sun _ wasp _ _ _ a

- this one is afraid of mustard and forks _ wasp _ with _ a

- with this baby _ was _ sleeping in a crib a

- this class is sneaking like a mouse $\mathrm{O}_{-} \mathrm{s}_{-}{ }_{-}$a The

control phase of experimental and pedagogical work of an experimental nature showed that 33\% of the subjects have a high level of formation of communicative UUD, $40 \%$ - an average level, and $27 \%$ - a low level.

Thus, we came to the conclusion that:

- the main task of Russian education is to organize effective conditions for students to achieve highquality educational results, universal educational actions, including communicative ones, which allow developing the linguistic personality of a younger student, the experience of independent activity, and the formation of an internal position ;

- the holistic formation and development of the linguistic personality of students is realized not only 
in the course of classroom activity, but also in extracurricular activities, involving the interaction of external conditions with internal processes, projecting a suitable "internal environment" that contributes to the rapid development of the personality of a primary school student, aimed at improving both creative and and intellectual abilities, cognitive interest, initiative, curiosity; - one of the productive means of forming a linguistic personality is the implementation of olympiads in the Russian language, which allows you to master the mechanism of independent search and processing of new information, encourages the development of a favorable atmosphere of selfdevelopment of the individual, the team, creating a holistic open space that encompasses both an educational institution and in contact with her environment, mastered by a team of teachers and students.

\section{References}

1. Ibragimova, G.F. Theoretical and methodological aspects of the formation of educational and cognitive competence of younger students in extracurricular intellectual activities [Text] / V.N. Gurov, G.F. Ibragimova // Innovations in education. - 2013. - No. 5. - C.5-13.

2. Karaulov, Yu.N. Russian language and linguistic personality [Text] / Yu.N. Karaulov. - M.: Publishing house LKI, 2010 .-- 427 p.

3. Moskalenko, T.N. Organization of extracurricular activities of students in the Russian language [Text] / T. N. Moskalenko // Practical advice to the teacher. - 2013. - No. 6. - with. 30-33. 
International Scientific and Practical Conference

PEDAGOGY AND MODERN EDUCATION

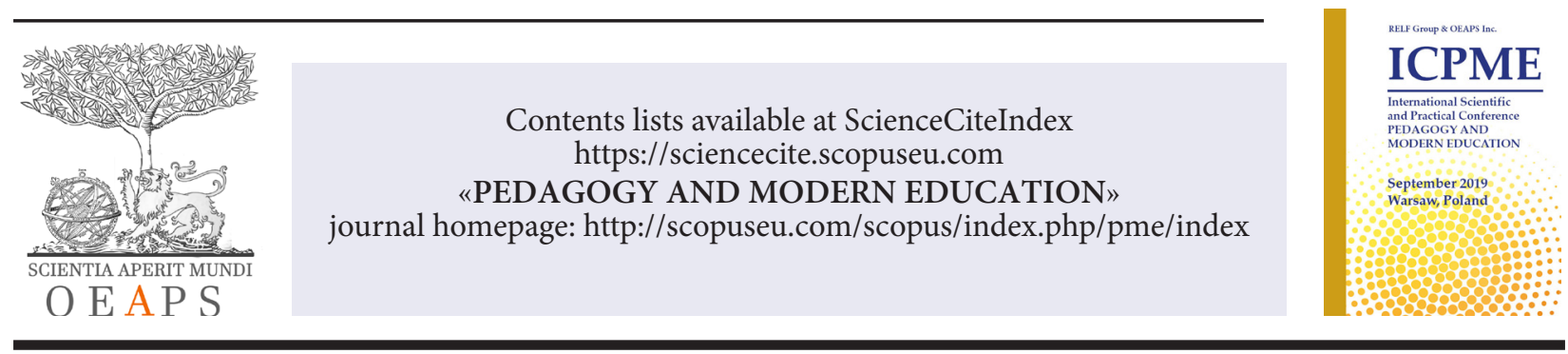

УДК: 37.015 .3

\title{
Невербальные средства общения в работе педагога
}

Ковалевич Ольга Алексеевна

Магистрант 2 курса, Балтийский федеральный университет имени Иммануила Канта, Россия, Калининград

Kowalewich96@gmail.com

\section{Nonverbal communication in the work of the educator}

Kovalevich Olga Alekseevna

Master's Degree student $2^{\text {nd }}$ course, Immanuel Kant Baltic Federal

University,Russia, Kaliningrad

\begin{abstract}
Аннотация
В статье рассматривается один из методов общения педагога и обучающегося, его важность в деятельности преподавателя и влияние на развитие познавательных процессов обучающегося.
\end{abstract}

\section{Abstract}

The article discusses one of the methods of communication between the teacher and the student, its importance in the activities of the teacher and the impact on the development of cognitive processes of the student.

Ключевые слова: невербальное общение, мимика, жесты, поза, педагогическое общение, проксемика

Key words: nonverbal communication, gestures, pose, pedagogical communication, proxemics

Коммуникация - одна из главных видов деятельности человека, поскольку охватывает и объединяет огромное количество сторон многогранной жизни людей. Еще с малых лет человек начинает овладевать первичными навыками общения, но при этом, достигая сознательного возраста, не все в достаточной мере умеют общаться.

(C) 2019 The Author. Published by OEAPS Inc. This is an open access article under the CC BY-NC-ND license (http://creativecommons.org/licenses/by-nc-nd/4.0/) 
Профессия педагог относится к типу профессий «человек - человек» (по типологии Е. А. Климова), и поэтому умение общаться одно из ведущих профессиональных качеств педагога.

Речь преподавателя - главный инструмент воздействия и взаимодействия, позволяющий передавать знания, навыки и умения своим ученикам. Педагог должен владеть высокой языковой культурой, иметь богатый словарный запас и разборчивую дикцию, уметь преподнести информацию с интонационной выразительностью и умеренной эмоциональной окраской.

Но необходимо учитывать, что информация передается как вербальными, так и невербальными средствами и важно делать акцент не только на речевой составляющей общения. Но тут возникает проблема, что некоторые представители педагогической профессии пренебрегают этим эффективным средством воздействия.

Невербальное взаимодействие осуществляется через такие средства как: мимика, жесты, поза, прикосновения, визуальное взаимодействие и др.

Для того чтобы узнать информацию, которая касается эмоционального состояния: чувства, намерения, переживания, настроение, отношения к чему-либо, мы обращаем внимание на жесты, мимику, позу, взгляд или используем их для того чтобы передать информацию, поскольку речь не всегда точно поможет нам это выразить.

Как отмечает Е.А. Петрова: «Жест, мимика, взгляд, поза подчас оказываются более выразительными и действенными, чем слова» [1].

Мимика несёт в себе большой информативный характер - иногда по лицу человека можно узнать больше, чем он хочет сказать, а доброжелательная улыбка поможет наладить и установить доверительные отношения или расположить к общению.

Очень часто в процессе обучения педагог не замечает и не придает значения средствам невербального общения, не задумываясь над тем нужным ли образом они задействованы и как они влияют на эмоциональную обстановку в коллективе. 
Особое место в невербальной коммуникации педагога занимают жесты. Характер подачи, который педагог использует для применения жестов, создает определенный настрой в аудитории.

Жестикуляцию преподавателя дети могут оценивать, как один из показателей его отношения к ним. Грамотный педагог всегда должен помнить об этом и использовать как инструмент в своей педагогической деятельности.

Как заметила Е.А. Петрова, в применении жестов прослеживается такая функция, как активизация познавательной деятельности. Внимание, память, восприятие, мышление и воображение все эти процессы задействуются, когда педагог сопровождает свою речь жестами. С их помощью может реализовываться активизация зрительного восприятия, памяти, наглядно-образного мышления[1].

Важными условиями эффективного процесса обучения являются внимание и заинтересованность учащихся, обеспечить которые могут жесты педагога. Особым воздействием на концентрацию внимания обладает именно жест, эмоциональная окраска которого привлекает внимание учеников. Чаще всего педагоги используют такие жесты, как жесты-подчеркивания, жесты-указания, жесты имитации, как средство организации внимания.

Невербальные средства общения в профессиональной сфере педагога имеют влиятельное значение в процессе взаимодействия преподавателя и учащегося. Необходимо учитывать не только речь ребенка, но и его взгляд, движение, жесты. Педагог должен уметь создавать эмоционально положительную атмосферу и коммуницировать с учениками даже не прибегая к средствам вербального общения, при этом очень строго контролировать свое невербальное поведение.

Педагог, который рационально использует приемы невербального общения в сочетании с вербальными и целенаправленно употребляет их в общении с учащимися, создает атмосферу живого урока делает его эмоционально-экспрессивным, интересным и запоминающимся для учеников. 


\section{Библиографический список}

1. Петрова Е.А. Жесты в педагогическом процессе. М.: Педагогическое общество России, 1998. - 222 c.

\section{The text of the article in English}

Communication is one of the main human activities, because it embraces and unites a huge number of aspects of the multifaceted life of people. From a young age, a person begins to master the primary communication skills, but at the same time, reaching a conscious age, not everyone is able to communicate sufficiently.

The profession of a teacher refers to the type of profession "person - person" (according to the typology of E. A. Klimov), and therefore the ability to communicate is one of the leading professional qualities of a teacher.

The teacher's speech is the main tool of influence and interaction, allowing you to transfer knowledge, skills and abilities to your students. The teacher must have a high linguistic culture, have a rich vocabulary and legible diction, be able to present information with intonational expressiveness and moderate emotional coloring.

But it must be borne in mind that information is transmitted both verbal and non-verbal means and it is important to focus not only on the speech component of communication. But here the problem arises that some representatives of the teaching profession neglect this effective means of influence.

Non-verbal interaction is carried out through such means as: facial expressions, gestures, posture, touch, visual interaction, etc.

In order to find out information regarding the emotional state: feelings, intentions, feelings, mood, attitude to something, we pay attention to gestures, facial expressions, posture, eyes, or use them to convey information, because speech does not always help us express it.

As noted by E.A. Petrova: "Gesture, facial expressions, gaze, posture sometimes turn out to be more expressive and effective than words" [1]. 
Mimicry carries a great informative character - sometimes you can learn more by the person's face than he wants to say, and a benevolent smile will help to establish and establish trusting relationships or encourage communication.

Very often in the learning process, the teacher does not notice and does not attach importance to the means of non-verbal communication, without thinking about whether they are involved in the right way and how they affect the emotional environment in the team.

A special place in non-verbal communication of a teacher is occupied by gestures. The nature of the presentation, which the teacher uses to use gestures, creates a certain mood in the audience.

Children can evaluate the teacher's gestures as one of the indicators of his attitude towards them. A competent teacher should always remember this and use it as a tool in his pedagogical activity.

As noted by E.A. Petrova, in the use of gestures can be traced such a function as the activation of cognitive activity. Attention, memory, perception, thinking and imagination all these processes are activated when the teacher accompanies his speech with gestures. With their help, activation of visual perception, memory, visual-figurative thinking can be realized [1].

Important conditions for an effective learning process are the attention and interest of students, which can be ensured by the teacher's gestures. The gesture, the emotional coloring of which attracts the attention of students, has a special effect on the concentration of attention. Most often, teachers use gestures such as underlining gestures, pointing gestures, imitation gestures, as a means of organizing attention.

Non-verbal means of communication in the professional sphere of a teacher are influential in the process of interaction between a teacher and a student. It is necessary to take into account not only the child's speech, but also his look, movement, gestures. The teacher should be able to create an emotionally positive atmosphere and communicate with students without even resorting to means of verbal communication, while very strictly controlling their non-verbal behavior.

A teacher who rationally uses non-verbal communication techniques in combination with verbal communication and purposefully uses them in communication with students creates an atmosphere of a live lesson that makes it emotionally expressive, interesting and memorable for students. 


\section{Bibliography}

1. Petrova E.A. Gestures in the pedagogical process. M .: Pedagogical Society of Russia, 1998. $222 \mathrm{p}$. 
International Scientific and Practical Conference

PEDAGOGY AND MODERN EDUCATION

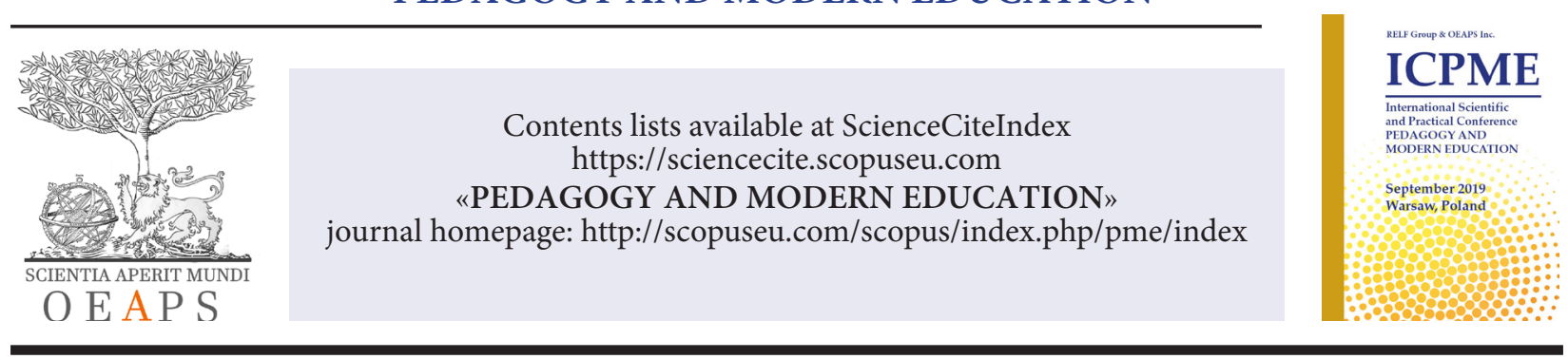

УДК 378. 095

Принцип гуманитаризации в содержании и методике естественнонаучной подготовки будущего учителя гуманитарного профиля

Афонина Раиса Николаевна

дочент

Алтайский государственный педагогический университет

Россия, г.Барнаул

ARN1960@yandex.ru

\title{
Principle of humanitarization in the contents and methods of natural scientific preparation of a future teacher of humanitarian profile
}

\author{
Afonina Raisa Nikolaevna \\ assistant professor \\ Altai State Pedagogical University \\ Russia, Barnaul
}

\begin{abstract}
Аннотация: Статья посвящена актуальной на сегодняшний день проблеме гуманитаризации содержания и методики естественнонаучного образования. Принцип гуманитаризации предполагает актуализацию гуманитарного потенциала учебных дисциплин посредством акцентирования философских, методологических, этических, мировоззренческих проблем, актуализацию исторического потенциала негуманитарных предметов.

Abstract: The article is devoted to the current problem of the humanization of the content of science education. The principle of humanization presupposes the actualization of the humanitarian potential of academic disciplines by emphasizing philosophical, methodological, ethical, worldview problems, and the updating of the historical potential of non-humanitarian subjects.
\end{abstract}

(C) 2019 The Author. Published by OEAPS Inc. This is an open access article under the CC BY-NC-ND license (http://creativecommons.org/licenses/by-nc-nd/4.0/) 
Ключевые слова: принцип гуманитаризации, содержание учебных дисциплин, естественнонаучное образование, современный учитель.

Keywords: the principle of humanization, the content of academic disciplines, science education, a modern teacher.

Принцип гуманитарнизации является одним из основополагающих принципов современного образования, он предполагает использование гуманитарного потенциала в каждой изучаемой области знания, и направлен на усвоение личностью общественно значимых ценностей, ориентацию на личность как социальную ценность общества.

Особенности содержания принципа гуманитаризации рассматриваются педагогамиисследователями с мировоззренческих, культурологических и аксеологических позиций. По мнению Б.С. Гершунского [3] гуманитаризация образования предполагает усиление внимания к тем знаниям, умениям, навыкам, в основе которых лежат гуманитарные методы познания действительности, которые формируют «человека духовного», личность с внутренней ориентированностью, способной противостоять давлению среды, сложившемуся стереотипному мышлению и поведению. И.Я. Лернер [6] рассматривал гуманитаризацию образования в культурологическом аспекте, обосновывая введение индивида в культуру как системное целое. В.Н. Сагатовский [7] рассматривает гуманитаризацию образования как его ориентацию на мир ценностей, жизненных смыслов и единство с природой. Н.И. Ильин [5] предлагает решение задачи гуманитаризации образования на основе использования возможностей гуманитарного потенциала изучаемой области знания, раскрытии роли науки в развитии материальной и духовной культуры человека и общества в целом, а также в развитии личности. Л.Я. Зорина [4] рассматривает гуманитаризацию в контексте «очеловечивания» учебного материала.

Система образования поставлена перед вызовом достижения нового понимания человеком своего предназначения и места в мире. Принцип гуманитаризации связан с общекультурными и общегуманистическими потребностями обучающихся, направлен на преодоление технократического мышления, изменение смыслового акцента на мир человека, человеческое измерение окружающего мира. Реализация принципа гуманитаризации на уровне содержания учебной дисциплины предполагает формирование необходимого запаса знаний, как социального опыта, передаваемого из прошлого в настоящее и будущее типов гуманитарного поведения, прошедших длительную апробацию, получивших ценностную окраску и объективно отвечающим потребностям общества. Предметные знания становятся гуманитарными при наличии условий осмысления обучающимися на основе понимания и диалога, если они связаны с личными смыслами, личностно ориентированы, субъектно значимы, выражают ценностное отношение обучающегося к окружающему миру и себе на основе личностно принятых гуманистических идей и ориентиров деятельности, норм и образцов поведения. Принцип гуманитаризации предполагает формирование ценностных потребностей и ориентаций, навыков ценностного отношения к действительности, когда 
объект оценивается с культурных, нравственных, этических и эстетических позиций в аспекте значимости для развития человека, для консолидации человечества [1].

Принцип гуманитаризации предполагает актуализацию гуманитарного потенциала учебных дисциплин посредством акцентирования философских, методологических, этических, мировоззренческих проблем, актуализацию исторического потенциала негуманитарных предметов. Основу гуманитаризации содержания образования составляют философские аспекты, вносимые в содержание учебных дисциплин. В современных условиях философский аспект содержания образования рассматривается как личностно развивающий фактор, способствующий углублению и расширению собственных жизненных ориентаций в мире, социуме.

Современная мировая ситуация, для которой характерны социальные, экологические, социально-нравственные и культурные проблемы глобального характера настоятельно требует подготовки специалиста нового типа, обладающего социальными и когнитивными характеристиками, включающими общую культуру, нравственные принципы, методологические принципы, активность, гражданскую активность, способность к диалогу, толерантность.

Современный учитель должен не только видеть и понимать тенденции глобального развития и учитывать их в своей профессиональной деятельности, но и уметь объяснять прогнозирование ситуаций, и способы предотвращения их негативных последствий. Формирование у будущего учителя общенаучной картины мира - это настоятельная потребность для полноценного осуществления профессиональной деятельности [2]. Естественнонаучная картина мира должна стать неотъемлимой частью общегуманитарной картины мира, а учитель должен быть вписанным в определенный культурно-исторический контекст своего времени, его глобальных проблем, общечеловеческих ценностей и быть способным осмыслить их через культурно-этические категории. Картина мира по выражению М. Хайдеггера [9], это не картина, изображающая мир, а мир, понятый в смысле такой картины, т.е. она способствует пониманию того, что человек может изменить мир к лучшему и найти нужные и правильные средства достижения этого.

Тенденции гуманитаризации естественных наук выражаются в изменении целей наук во благо человека. Одной из важнейших функций педагога, как показано в исследовании И.И. Соколовой [8] становится трансляция культуры на основе личностно-смыслового освоения ценностей, связанных со взаимоотношениями Мира и Человека, процессами познания. В естественнонаучном образовании такая ориентация предполагает построение содержания с позиций формирования целостного научного представления о мире и его проблемах, нравственных ценностей и мотиваций, значимости учебного материала для жизненной практики, в том числе и личной. 


\section{Список литературы}

1. Афонина, Р.Н. Естественнонаучное образование студентов гуманитарного вуза в контексте конвергентного подхода / Р.Н. Афонина // Ломоносовские чтения на Алтае. - Барнаул, 2013.С.297-302.

2. Афонина, Р.Н. Культурно-антропологическая направленность тенденций обновления высшего профессионального образования [Электронный ресурс] / Р.Н. Афонина // Новые образовательные технологии в вузе. - Режим доступа: http:// www. urfu.ru свободный.- Загл. с экрана.

3. Гершунский, Б.С. Философия образования для XXI века / Б.С. Гершунский. - М.: Московский психолого-социальный институт, Флинта, 1998. - 432 с.

4. Зорина, Л.Я. Отражение идей самоорганизации в содержании образования / Л.Я. Зорина // Педагогика. - 1996. - №4. - С. 105-109.

5. Ильин, Н.И. Формирование гуманитарных знаний у учащихся в процессе преподавания естественнонаучных дисциплин в средней школе : автореф. дис. ... канд. пед. наук / Н.И. Ильин. - Казань, 1996. - 18 с.

6. Лернер, И.Я. Процесс обучения и его закономерности / И.Я. Лернер. - М.: Знание, 1980. $-96 \mathrm{c}$.

7. Сагатовский, В.Н. Ценностное основание гуманитарной экспертизы / В.Н. Сагатовский // Гуманитарная экспертиза: возможности и перспективы. - Новосибирск, 1992. - С. 9-33.

8. Соколова, И.И. Теоретические основы конструирования образовательных профессиональных программ высшего педагогического образования по направлению «Естествознание» : автореф. дис. ...д-ра. пед. наук / И.И. Соколова. - СПб.: РГПУ им. А.И. Герцена, 1998. - 39 с.

9. Хайдеггер, М. Письмо о гуманизме /М. Хайдеггер // Время и бытие. Статьи и выступления. - М. : Республика, 1993. - 201 с.

\section{The text of the article in English}

The principle of humanitarianization is one of the fundamental principles of modern education, it involves the use of the humanitarian potential in each studied field of knowledge, and is aimed at the assimilation of socially significant values by a person, focusing on a person as a social value of a society.

Peculiarities of the content of the principle of humanization are considered by pedagogical researchers from worldview, cultural and axiological positions. According to B.S. Gershunsky [3] the humanization of education involves increasing attention to those knowledge, skills, skills, which are based on humanitarian methods of cognition of reality, which form a "spiritual person", a person with an inner orientation, able to withstand environmental pressure, prevailing stereotyped thinking and behavior. AND I. Lerner [6] considered the humanitarianization of education in the cultural aspect, justifying the introduction of the individual into culture as a systemic whole. 
V.N. Sagatovsky [7] considers the humanization of education as its orientation towards the world of values, life meanings and unity with nature. N.I. Ilyin [5] proposes a solution to the problem of humanizing education through the use of the humanitarian potential of the studied field of knowledge, the disclosure of the role of science in the development of the material and spiritual culture of man and society as a whole, as well as in personality development. L.Ya. Zorina [4] considers humanization in the context of the "humanization" of educational material.

The education system is faced with the challenge of achieving a new understanding by man of his mission and place in the world. The principle of humanization is associated with the general cultural and general humanistic needs of students, aimed at overcoming technocratic thinking, changing the semantic emphasis on the human world, the human dimension of the world. The implementation of the principle of humanization at the level of the content of the academic discipline involves the formation of the necessary stock of knowledge, as social experience, transmitted from the past to the present and the future of types of humanitarian behavior that have undergone lengthy testing, received a valuable coloring and objectively meet the needs of society. Subject knowledge becomes humanitarian in the presence of conditions of understanding by students on the basis of understanding and dialogue, if they are associated with personal meanings, are personally oriented, subjectively significant, express the student's value attitude to the world around him and himself on the basis of personally accepted humanistic ideas and orientations of activity, norms and patterns behavior. The principle of humanization involves the formation of value needs and orientations, skills of a value attitude to reality, when an object is evaluated from cultural, moral, ethical and aesthetic positions in terms of significance for human development, for the consolidation of humanity [1].

The principle of humanization presupposes the actualization of the humanitarian potential of academic disciplines by emphasizing philosophical, methodological, ethical, worldview problems, and the updating of the historical potential of non-humanitarian subjects. The basis of the humanization of the content of education is philosophical aspects introduced in the content of academic disciplines. In modern conditions, the philosophical aspect of the content of education is considered as a personally developing factor that contributes to the deepening and expansion of their own life orientations in the world and society.

The current global situation, which is characterized by social, environmental, social, moral and cultural problems of a global nature, urgently requires the training of a new type of specialist with social and cognitive characteristics, including a common culture, moral principles, methodological principles, activity, civic activism, and dialogue tolerance.

A modern teacher should not only see and understand global development trends and take them into account in his professional activity, but also be able to explain forecasting situations, and ways to prevent their negative consequences. The formation of a future scientific picture of the world by a future teacher is an urgent need for the full implementation of professional activities [2]. The natural-scientific picture of the world should become an integral part of the general humanitarian 
picture of the world, and the teacher should be inscribed in a certain cultural and historical context of his time, his global problems, universal values and be able to comprehend them through cultural and ethical categories. The picture of the world, as expressed by M. Heidegger [9], is not a picture depicting the world, but a world understood in the sense of such a picture, i.e. it contributes to the understanding that a person can change the world for the better and find the necessary and correct means of achieving this.

The trends in the humanization of the natural sciences are expressed in a change in the goals of science for the benefit of man. One of the most important functions of a teacher, as shown in a study by I.I. Sokolova [8] becomes the broadcast of culture on the basis of personal-semantic development of values associated with the relationship of the World and Man, the processes of cognition. In science education, such an orientation involves the construction of content from the standpoint of the formation of a holistic scientific understanding of the world and its problems, moral values and motivations, the importance of educational material for life practice, including personal one.

\section{References}

1. Afonina, R.N. Natural science education of students of a humanitarian university in the context of a convergent approach / R.N. Afonina // Lomonosov readings in Altai. - Barnaul, 2013. - S.297302.

2. Afonina, R.N. Cultural and anthropological orientation of the trends of renewal of higher professional education [Electronic resource] / R.N. Afonina // New educational technologies at the university. - Access mode: http: // www. urfu.ru free. - Zagl. from the screen.

3. Gershunsky, B.S. Education Philosophy for the 21st Century / B.S. Gershunsky. - M.: Moscow Psychological and Social Institute, Flint, 1998. - 432 p.

4. Zorina, L.Ya. Reflection of the ideas of self-organization in the content of education / L.Ya. Zorina // Pedagogy. - 1996. - No. 4. - S. 105-109.

5. Ilyin, N.I. The formation of humanitarian knowledge in students in the process of teaching natural sciences in high school: author. dis. ... cand. ped sciences / N.I. Ilyin. - Kazan, 1996 --- 18 p. 6. Lerner, I.Ya. The learning process and its laws / I.Ya. Lerner. - M.: Knowledge, 1980 --- 96 p.

7. Sagatovsky, V.N. The value basis of humanitarian expertise / V.N. Sagatovsky // Humanitarian expertise: opportunities and prospects. - Novosibirsk, 1992 .-- S. 9-33.

8. Sokolova, I.I. The theoretical basis for the design of educational professional programs of higher pedagogical education in the direction of "Natural Sciences": author. dis. ... dr. ped sciences / I.I. Sokolova. - SPb .: RSPU im. A.I. Herzen, 1998 .-- 39 p.

9. Heidegger, M. Letter of Humanism / M. Heidegger // Time and Being. Articles and speeches. M.: Republic, 1993 .-- 201 p. 
International Scientific and Practical Conference

PEDAGOGY AND MODERN EDUCATION

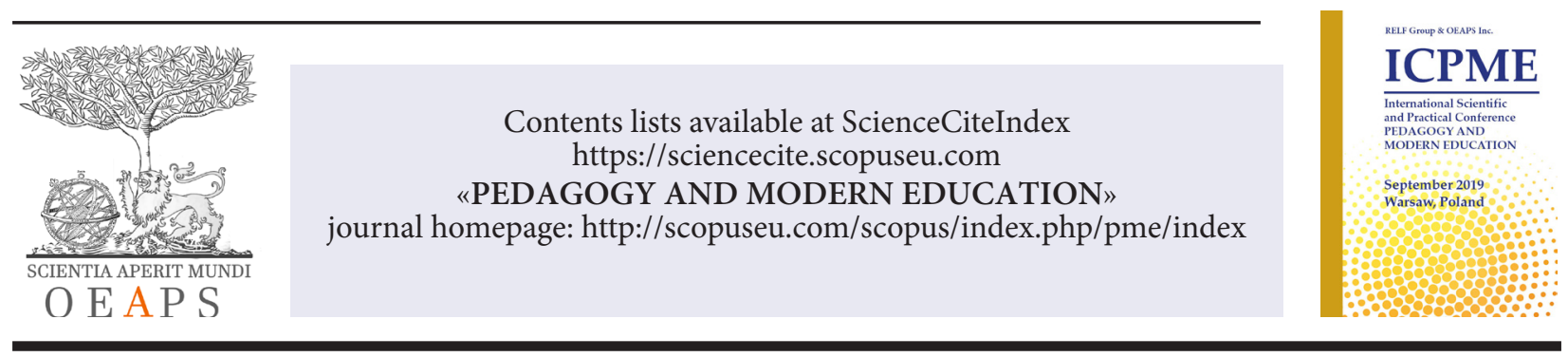

УДК 378. 095

Теоретические аспекты гуманитаризации и гуманизации образовательного процесса

Афонина Раиса Николаевна

доиент

Алтайский государственный педагогический университет

Россия, г.Барнаул

ARN1960@yandex.ru

Лесных Елена Алексеевна

доиент кафедры информатики

Алтайский государственный аграрный университет,

РФ, г. Барнаул

lesnyh74@mail.ru

\title{
Theoretical bases of humanitarization and humanization of educational proces
}

\author{
Afonina Raisa Nikolaevna \\ assistant professor \\ Altai State Pedagogical University \\ Russia, Barnaul \\ ARN1960@yandex.ru \\ Lesnykh Elena Alekseevna \\ assistant professor, \\ Department of Computer Science, \\ Altai State Agrarian University, \\ $R F$, Barnaul \\ lesnyh74@mail.ru
}

(c) 2019 The Author. Published by OEAPS Inc. This is an open access article under the CC BY-NC-ND license (http://creativecommons.org/licenses/by-nc-nd/4.0/) 
Аннотация: В статье рассматриваются теоретические аспекты гуманитаризации и гуманизации современного образовательного процесса. Проблема гуманитаризации образования актуализируется в связи с формированием гуманистического мировоззрения, гуманитарной культуры личности. Гуманизация представляется как развитие и освоение идей гуманизма, понимание взаимоотношений материального и духовного, природы и человека.

Abstract: The article deals with the theoretical aspects of humanization and humanization of the modern educational process. The problem of humanization of education is actualized in connection with the formation of humanistic worldview, humanitarian culture of the individual. Humanization is represented as the development and development of ideas of humanism, understanding the relationship of material and spiritual, nature and man.

Ключевые слова: гуманитаризация, гуманизация, современный образовательный процесс, система высшего образования.

Key words: humanitarization, humanization, modern educational process, higher education system.

В современных условиях развития системы знаний о мире, человеке и обществе возникла объективная необходимость в повышении роли фундаментальной базы образования, построенной на основе органического единства его естественнонаучной и гуманитарной составляющей. Большинство исследователей называют две группы причин необходимости повышения фундаментальной базы образования: первая группа причин связанас глобальными проблемами цивилизации, вторая группа причин обусловлена тем, что мировое сообщество в последнее десятилетие ставит в центр системы образования приоритет личности, развитие ее творческого потенциала. Одной из ведущих тенденций в современной педагогике является ее обращение к мировоззренческим основаниям, возвращение к личности, к ценностям ее духовного мира.

Гуманизация представляется как развитие и освоение идей гуманизма, понимание взаимоотношений материального и духовного, природы и человека. В философии гуманизм понимается как процесс осознания человеком своей духовности, его взаимоотношений с внешним миром. Особое значение в целостной системе «мир и человек» имеет человек, понимаемый как целостная личность, реализующая свой творческий потенциал во взаимодействии с миром: природой, обществом, другими людьми. Идеи гуманизации в образовании становятся возможны тогда, когда в центре образования находится личность, которая характеризуется с позиции ценностного аспекта. Социальный заказ все более ориентирован не только на человека знающего, умеющего, но и осознающего, понимающего последствия своей деятельности, обладающим широким спектром общекультурных доминант.

В современной психолого-педагогической литературе достаточно много внимания уделяется понятиям «гуманизация» и «гуманитаризация» образования, однако существует неоднозначность толкования этих понятий. Этимологические основания анализа этих 
понятий позволяют установить момент схожести: слово «гуманизм» происходит от «humanus» - человечный, а слово «гуманитарный» - от «humanitas» - человеческая природа, духовная культура. Однако содержательные основания анализа свидетельствуют о том, что эти понятия не тождественны.

В психолого-педагогическом словаре понятие гуманитаризация образования определяется как «система мер, направленных на приоритетное развитие общекультурных компонентов в содержании образования и, таким образом, на формирование личной зрелости обучаемых» [5]. И.Д. Пехлецкий [4] считает гуманитаризацию средством гуманизации. В исследовании Н.И. Ильина [2] подчеркивается, что гуманитаризация является воплощением на практике идей гуманизации. Автор отмечает, что под гуманитаризацией (очеловечиванием) следует понимать такие главные аспекты обучения и воспитания как формирование истинно гуманистического мышления, изменение отношений между преподавателем и обучающимися и соответствующий выбор форм организации учебных занятий, акцентированный отбор содержания конкретной учебной дисциплины.

В нашем исследовании мы будем придерживаться позиции В.М. Симонова [6], считая, что гуманизация - это поворот всей системы образования к человеку, его ценностям, а процесс гуманитаризации является одним из механизмов гуманизации образования.

Гуманистический подход к природе и человеку как равноправным партнерам в коэволюции, предполагает дальнейший поиск путей развития и становления экологической культуры. Главной задачей образовательной практики, по утверждению А.В. Морозова и Д.В. Чернилевского [3], становится не только обучение законам природы и общества, но и помощь в деятельном овладении гуманистической методологией познавательной творческой деятельности и гармонизации отношений в системе «человек - природа - общество».

В контексте рассматриваемой проблемы гуманизм, как форма общественной связи между людьми приобретает завершенную форму тогда, когда одновременно становится формой связи между человеком и природой. Гуманистическая образовательная среда наиболее полно способствует самоактуализации личности - стремлению к возможно более полному выявлению и развитию своих способностей и возможностей. Условия, в которых осуществляется образовательный процесс, основанный на гуманистической модели образования, способствует не только лучшему усвоению учебного материала, но и личностному росту обучающихся.

Гуманизация образования, как постулируется в исследовании А.Г. Асмолова [1], это не просто отказ от авторитарности и опоры на внешнее стимулирование овладения знаниями, а апелляция к глубинным горизонтам сознания личности, установка на ее свободное самовыражение, на раскрытие ее творческого потенциала. Гуманизация образования проявляется также в его демократизации, обеспечении возможности выбора индивидуальных образовательных маршрутов, сочетании инвариантности и вариативности содержания образования, открытости и ступенчатости системы образования, сочетании 
дифференциации с интегративными процессами в обучении. Решение этих задач видится в научно обоснованной организации образовательного пространства, образовательных профессиональных программ, предполагающих единство научной, профессиональной, методологической подготовки в сочетании с комплексом методов обучения на основе личностно ориентированного обучения, деятельностного подхода, позволяющего готовить специалиста в сфере образования в контексте функций, которые ему предстоит выполнять.

В этом аспекте гуманитаризация образования рассматривается как интегрирующее, системообразующее начало и необходимое условие решения задач профессионального образования. Гуманистическая образовательная среда наиболее полно способствует самоактуализации личности - стремлению к возможно более полному выявлению и развитию своих способностей и возможностей. Гуманитаризация образования определяет в качестве основных ориентиров образовательного процесса развитие интеллектуальных и творческих способностей личности, синтез различных типов знаний с этическим осмыслением результатов деятельности, выработку способности делать выбор и принимать за него ответственность.

\section{Список литературы}

1. Асмолов, А.Г. Психология личности [Текст] / А.Г.Асмолов. - М.: МГУ, 1990. - 367 с.

2. Ильин Н.И. Формирование гуманитарных знаний у учащихся в процессе преподавания естественнонаучных дисциплин в средней школе [Текст] : автореф. дис. ... канд. пед. наук / Н.И. Ильин. - Казань, 1996. - 18 с.

3. Морозов, А.В. Креативная педагогика и психология [Текст] /А.В. Морозов, Д.В. Чернилевский. - М.: Академический проект, 2004. - 500 с.

4. Пехлецкий, И.Д. Компоненты индивидуального стиля преподавания: спецкурс-практикум [Текст] / И.Д. Пехлецкий. - Пермь, 1990. - 138 с.

5. Психолого-педагогический словарь для учителей и руководителей общеобразовательных учреждений [Текст] / Под ред. П.И. Пидкасистого. - Ростов-на-Дону: Феникс, 1998. - 544 с. 6. Симонов, В.М. Дидактические основы естественнонаучного образования: теория и практика реализации гуманитарной парадигмы наук [Текст]: автореф. дис. ... д-ра пед. наук / В.М. Симонов. - Волгоград: ВГПУ, 2000. - 42 с.

\section{The text of the article in English}

In modern conditions of the development of a system of knowledge about the world, man and society, an objective need arose to increase the role of the fundamental base of education, built on the basis of the organic unity of its natural science and humanitarian component. Most researchers call two groups of reasons for the need to increase the fundamental base of education: the first group of reasons is related to the global problems of civilization, the second group of reasons is due to the fact that the world community has placed the priority of the individual and the development of 
her creative potential at the center of the educational system. One of the leading trends in modern pedagogy is its appeal to ideological foundations, a return to the individual, to the values of her spiritual world.

Humanization is represented as the development and assimilation of the ideas of humanism, an understanding of the relationship between material and spiritual, nature and man. In philosophy, humanism is understood as a process of a person's awareness of his spirituality, his relationship with the outside world. Of particular importance in the holistic system of "peace and man" is a person understood as an integral person, realizing his creative potential in interaction with the world: nature, society, other people. The ideas of humanization in education become possible when a person who is characterized by the value aspect is at the center of education. The social order is more and more focused not only on a person who knows, knows how, but also is aware, understands the consequences of his activities, who has a wide range of general cultural dominants. In modern psychological and pedagogical literature, a lot of attention is paid to the concepts of "humanization" and "humanization" of education, but there is an ambiguity in the interpretation of these concepts. The etymological foundations of the analysis of these concepts allow us to establish a moment of similarity: the word "humanism" comes from "humanus" - human, and the word "humanitarian" - from "humanitas" - human nature, spiritual culture. However, the substantive foundations of the analysis indicate that these concepts are not identical.

In the psychological and pedagogical dictionary, the concept of humanization of education is defined as "a system of measures aimed at the priority development of general cultural components in the content of education and, thus, the formation of personal maturity of students" [5]. I.D. Pekhletsky [4] considers humanization a means of humanization. In the study of N.I. Ilyin [2] emphasizes that humanization is the embodiment in practice of the ideas of humanization. The author notes that by humanization (humanization) it is necessary to understand such main aspects of teaching and upbringing as the formation of truly humanistic thinking, a change in the relationship between the teacher and students and the corresponding choice of forms for organizing training sessions, accented selection of the content of a particular academic discipline.

In our study, we will adhere to the position of V.M. Simonova [6], believing that humanization is a turn of the entire education system towards a person, his values, and the process of humanization is one of the mechanisms of humanization of education.

The humanistic approach to nature and man as equal partners in co-evolution, involves a further search for the development and establishment of environmental culture. The main task of educational practice, according to A.V. Morozova and D.V. Chernilevsky [3], it becomes not only teaching the laws of nature and society, but also help in the active mastery of the humanistic methodology of cognitive creative activity and harmonization of relations in the system "man - nature - society". In the context of the problem under consideration, humanism, as a form of social communication between people, takes on a completed form when it simultaneously becomes a form of 
communication between man and nature. The humanistic educational environment most fully contributes to the self-actualization of personality - the desire for the fullest possible identification and development of their abilities and capabilities. The conditions in which the educational process based on the humanistic model of education is carried out contributes not only to better learning of the educational material, but also to the personal growth of students.

The humanization of education, as postulated in the study of A.G. Asmolov [1], this is not just a rejection of authoritarianism and reliance on external stimulation of knowledge acquisition, but an appeal to the deep horizons of the personality's consciousness, the installation on its free self-expression, on the disclosure of its creative potential. The humanization of education is also manifested in its democratization, providing the possibility of choosing individual educational routes, combining the invariance and variability of the content of education, openness and stepwise education system, combining differentiation with integrative processes in learning. The solution to these problems is seen in the scientifically substantiated organization of the educational space, educational professional programs that imply the unity of scientific, professional, methodological training in combination with a set of teaching methods based on personality-oriented learning, an active approach that allows you to prepare a specialist in the field of education in the context of the functions that he to be performed.

In this aspect, the humanization of education is seen as an integrating, system-forming principle and a necessary condition for solving the problems of vocational education. The humanistic educational environment most fully contributes to the self-actualization of personality - the desire for the fullest possible identification and development of their abilities and capabilities. The humanization of education defines as the main guidelines of the educational process the development of the intellectual and creative abilities of the individual, the synthesis of various types of knowledge with an ethical understanding of the results of activity, the development of the ability to make choices and take responsibility for it.

\section{References}

1. Asmolov, A.G. Psychology of personality [Text] / A.G. Asmolov. - M .: MSU, 1990 .- 367 p.

2. Ilyin N.I. The formation of humanitarian knowledge in students in the process of teaching natural sciences in high school [Text]: author. dis. ... cand. ped sciences / N.I. Ilyin. - Kazan, 1996 -- 18 p. 3. Morozov, A.V. Creative pedagogy and psychology [Text] / A.B. Morozov, D.V. Chernilevsky. M.: Academic project, 2004. - 500 p.

4. Pekhletsky, I.D. Components of an individual teaching style: a special practical course [Text] / I.D. Pekhletsky. - Perm, 1990 .- 138 p.

5. Psychological and pedagogical dictionary for teachers and heads of educational institutions [Text] / Ed. P.I. Fagot. - Rostov-on-Don: Phoenix, 1998 .- 544 p.

6. Simonov, V.M. The didactic foundations of science education: theory and practice of implementing the humanitarian paradigm of sciences [Text]: author. dis. ... dr ped. sciences / V.M. Simonov. Volgograd: Voronezh State Pedagogical University, 2000 .- 42 p. 
International Scientific and Practical Conference

PEDAGOGY AND MODERN EDUCATION

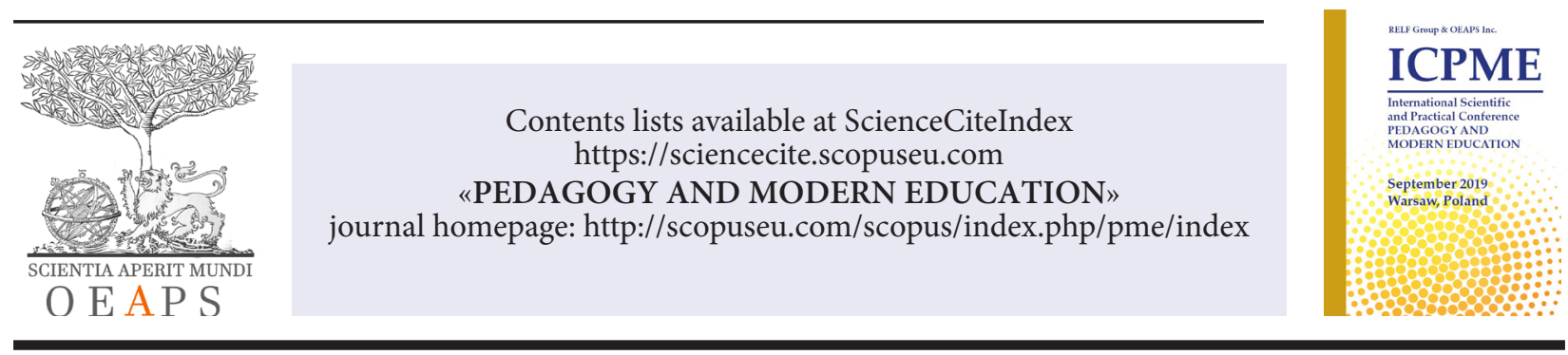

УДК 378.4

Моделирование процесса профессиональной адаптации будущих педагогов специального образования на младших курсах обучения в вузе

Ряполова Яна Игоревна

аспирант кафедры технологий психолого-педагогического и специального образования ФГБОУ ВО «Орловский государственный университет имени И.С. Тургенева», РФ, г. Орёл

iana0491@mail.ru

\section{Образцов Павел Иванович}

доктор педагогических наук, профессор кафедры технологий психолого-педагогического и специиального образования ФГБОУ ВО «Орловский государственный университет имени И.С. Тургенева», РФ, г. Орёл

kind@orel.ru

Modeling of the process of professional adaptation of future teachers of special education in Junior courses at the University

Ryapolova Yana Igorevna

Postgraduate at the Department of technologies of psycho-pedagogical and special education, Orel State University

Russia, Orel

Obraztsov Pavel Ivanovich

Doctor of pedagogical Sciences, Professor of the Department of technologies of psychopedagogical and special education, Orel State University

Russia, Orel

(c) 2019 The Author. Published by OEAPS Inc. This is an open access article under the CC BY-NC-ND license (http://creativecommons.org/licenses/by-nc-nd/4.0/) 


\begin{abstract}
Аннотация
В статье рассматриваются особенности профессиональной адаптации будущих педагогов специального образования на начальном этапе обучения в вузе. Уточнены педагогические условия, влияющие на адаптационные процессы. Отмечена специфика профессиональной деятельности педагогов специального образования. Представлена модель профессиональной адаптации будущих коррекционных педагогов в системе высшего профессионального образования на начальном этапе обучения.
\end{abstract}

\begin{abstract}
The article considers the peculiarities of professional adaptation of future teachers of special education at the initial stage of study in the university. Pedagogical conditions affecting adaptation processes have been clarified. The specifics of professional activity of teachers of special education were noted. A model of professional adaptation of future correction teachers in the system of higher vocational education at the initial stage of education is presented.
\end{abstract}

Ключевые слова: профессиональная адаптация, педагог специального образования, педагогическое содействие, мотивационная готовность, модель профессиональной адаптации.

Key words: professional adaptation, teacher of vocational education, pedagogical assistance, motivational readiness, model of professional adaptation.

Период профессиональной адаптации студентов на младших курсах обучения в вузе один из самых сложных. Это объясняется тем, что данный этап является переходным между моментом выбора профессии и началом трудовой деятельности. Для первокурсников будущих коррекционных педагогов профессиональная адаптация играет особую роль, т.к. её эффективность влияет на развитие устойчивого положительного отношения к будущей профессии.

В наших исследованиях отмечалось, что под студентом-будущим педагогом специального образования подразумевается активный деятель, инициативный, готовый к реализации собственных знаний, умений, навыков. Однако не всегда студент-первокурсник проявляет подобные качества. Как правило, самореализации студента помогает преподавательский состав вуза, создавая необходимые условия. Ю.В. Стафеева справедливо отмечает, что адаптация человека может быть активной или пассивной. Так, студент выбирает тот или иной способ адаптации, а педагог, в свою очередь, осуществляет деятельность «по активизации внутренних созидательных сил растущего человека и развитию у него способностей творить себя». [6, с. 12] 
Автором выявлены следующие факторы педагогической поддержки адаптации студентов младших курсов к условиям обучения в вузе:

- совместная творческая деятельность преподавателей и студентов;

- система самостоятельной работы в вузе;

- создание в вузе креативной образовательной среды;

- вовлечение студентов в жизнедеятельность коллектива академической группы;

- обучение студентов эффективным способам учебной самоорганизации;

- создание благоприятного взаимопринимаемого психологического климата в студенческом коллективе;

- педагогическая помощь первокурсникам в обретении достойного статуса в студенческом сообществе. [6, с. 12-14]

Вышеперечисленные факторы можно считать актуальными для содействия успешности профессиональной адаптации, т.к. подобные педагогические условия способствуют профессиональному самоопределению студентов. Однако названные действия должны быть профессионально направленными. Считаем, что при подготовке будущих учителей специального образования в качестве дополнительного фактора можно выделить создание условий для самообразования и самовоспитания, т.к. это неотъемлемая часть педагогической деятельности, в частности в работе с «особенными» детьми.

Достаточное количество исследований посвящено процессу профессиональной адаптации студентов в условиях обучения в вузе. Интересна работа О.Р. Кокориной «Создание условий для адаптации студентов в вузе как результат педагогического содействия». Автор видит суть содействия адаптации личности в совместной деятельности участников образовательного процесса. Педагог оказывает помощь студенту в достижении учебных целей. [4, с. 31] На наш взгляд, педагогическое содействие играет ведущую роль в том числе в процессе профессиональной адаптации. Именно педагог способствует раскрытию профессиональной направленности учебно-воспитательного процесса.

Критерии оценки успешности адаптации студентов-первокурсников нашли свое отражение в трудах Ю.И. Толстых. И.А. Варламова и Н.А. Чурляева представили модель процесса адаптациистудентовтехническоговуза.О.А.Голубева, Т.Ф.Глухова,О.Н.Маркина, О.В.Светус выявили основы профессиональной адаптации и разработали модель профессиональной адаптации студентов - будущих педагогов физической культуры в процессе обучения в вузе. Среди факторов, положительно влияющих на адаптационные процессы в период обучения, авторы выделяют: мотивационную готовность к профессиональной деятельности, процесс формирования профессиональной компетенции педагога, психолого-педагогическое 
сопровождение. [3, с. 3] Разделяем мнение авторов в том, что наиболее быстрому процессу адаптации студентов к новым условиям способствуют мероприятия, проводимые в университете. Мотивационный компонент также является важнейшей составляющей адаптации к профессии на начальном этапе обучения.

В модели профессионально-личностной готовности будущих учителей к коррекционной работе с учащимися в современных условиях, разработанной Е.Г. Глушко, фигурирует эмоционально-волевой компонент. Он является значимым, на наш взгляд, т.к. отражает положительное отношение к профессии учителя (в частности специального образования), стремление понять «особенного» ребенка, проявление справедливости, самообладания, дружелюбия во взаимоотношениях с детьми, терпение, проявление чувства ответственности за результаты коррекционной работы, способность к саморегуляции в сложных педагогических ситуациях, рефлексивную готовность к оценке собственных возможностей. $[2$, c. 16]

В результате проведенного анализа научно-методической литературы выявлены основы профессиональной адаптации будущих учителей специального образования. Разработанная нами модель (рис. 1) позволяет наиболее полно представить процесс профессиональной адаптации будущих коррекционных педагогов в системе высшего профессионального образования на начальном этапе обучения. 


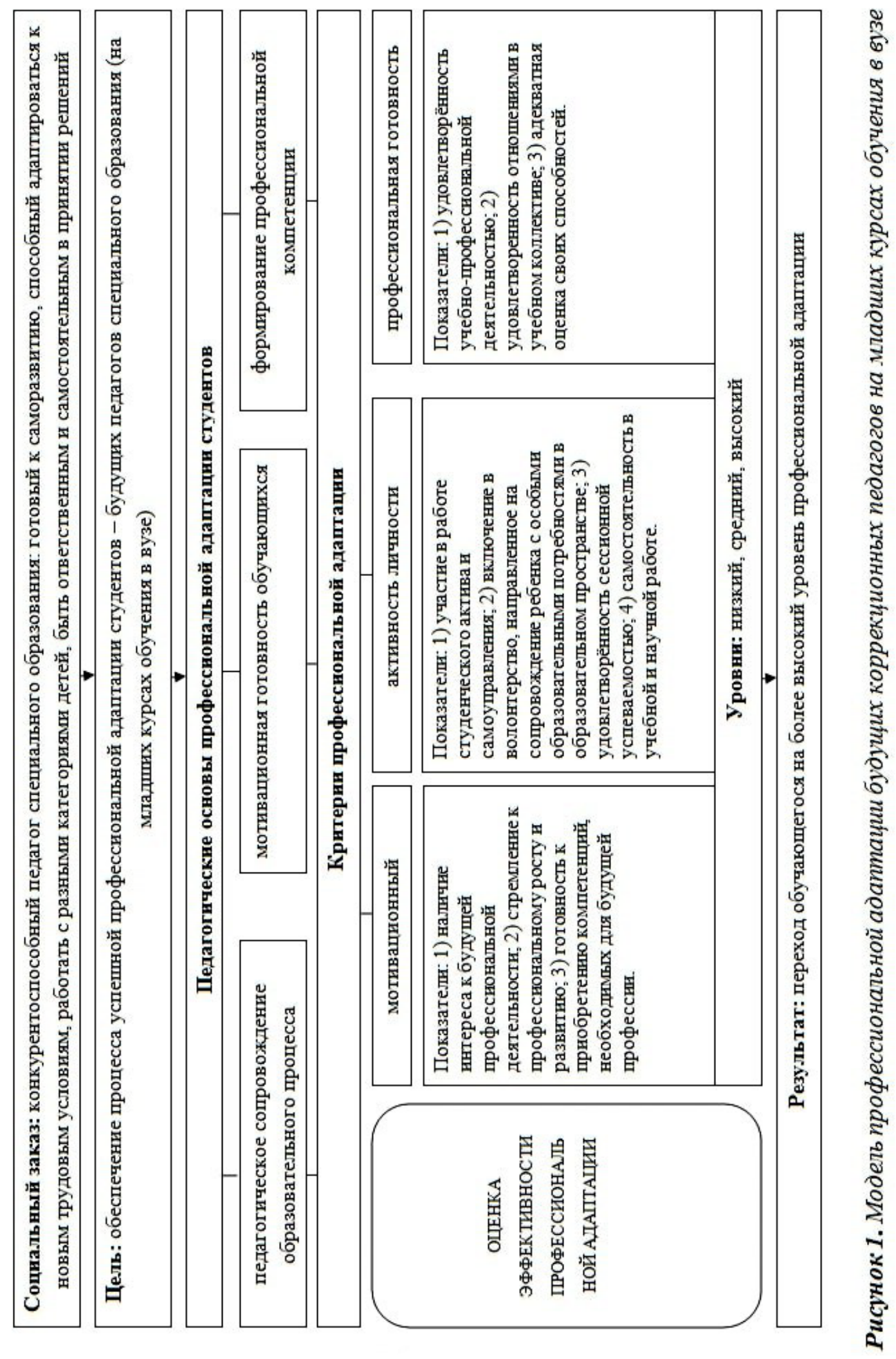


Процесс профессиональной адаптации будет наиболее эффективным при наличии: мотивационной готовности учащихся к профессиональной деятельности, процесса формирования профессиональной компетенции педагога специального образования, педагогического сопровождения образовательного процесса.

Мотивационная готовность проявляется на этапе выбора профессии и влияет на дальнейшее профессиональное обучение. При этом создание необходимых педагогических условий позволит сформировать у студентов устойчивую профессиональную направленность, а также поможет им быстрее адаптироваться к будущей профессии на начальном этапе обучения. Под педагогическими условиями подразумеваем педагогическое сопровождение студентов, направленное на помощь в освоении компонентов будущей профессии, стимулирование творческой активности личности, развитие профессионального интереса.

В ходе проведения исследования были выявлены показатели, критерии и уровни оценки эффективности профессиональной адаптации будущих коррекционных педагогов на начальном этапе обучения в вузе.

В состав мотивационного критерия входит: наличие интереса к будущей профессиональной деятельности, стремление к профессиональному росту и развитию, готовность к приобретению компетенций, необходимых для будущей профессии.

Показателями критерия, который мы обозначили как активность личности, являются: участие в работе студенческого актива и самоуправления, включение в волонтерство, направленное на сопровождение ребенка с особыми образовательными потребностями в образовательном пространстве, удовлетворённость сессионной успеваемостью, самостоятельность в учебной и научной работе.

Основу профессиональной готовности (на младших курсах обучения) составляют: удовлетворённость учебно-профессиональной деятельностью, удовлетворенность отношениями в учебном коллективе, адекватная оценка своих способностей.

Предполагаем, что в результате соблюдения всех условий (при педагогическом содействии, направленном на помощь в профессиональном самоопределении студентов младших курсов; проведении мероприятий, направленных на формирование устойчивого профессионального интереса; создании условий для самообразования и самовоспитания) уровень профессиональной адаптации студентов повысится.

Перспективным направлением исследования представляется анализ компонентов профессиональной адаптации, а также разработка инструментария для измерения показателей с учетом специфики профессиональной деятельности педагогов специального образования. 


\section{Список литературы}

1. Варламова И.А. и Чурляева Н.А. Моделирование процесса адаптации студентов младших курсов к профессиональному образованию в технических вузах // Личность, семья и общество: вопросы педагогики и психологии: сб. ст. по матер. XXXIV междунар. науч.практ. конф. №11(34). Часть I. - Новосибирск: СибАК, 2013.

2. Глушко Е.Г. Подготовка будущих учителей к коррекционной работе с учащимися в условиях педагогического колледжа: Автореф... дис. кан. пед. наук. - Ростов-на-Дону: 2004. -24 c.

3. Голубева О.А., Глухова Т.Ф., Маркина О.Н., Светус О.В. Модель профессиональной адаптации студентов - будущих педагогов физической культуры в процессе обучения в вузе // Интернет-журнал «Мир науки», 2018 №6, https://mir-nauki.com/PDF/93PDMN618. pdf

4. Кокорина О.Р. Создание условий для адаптации студентов в вузе как результат педагогического содействия // Педагогика и психология профессионального образования, №3 - 2011. - С. 29-35.

5. Ряполова Я.И. Критерии оценки успешности профессиональной адаптации будущих педагогов специального образования на младших курсах обучения в вузе // Научный журнал «Вопросы педагогики», ISSN 2518-1793, №3 - 2019. - С. 243-247.

6. Стафеева Ю.В Педагогическая поддержка адаптации студентов младших курсов к условиям обучения в вузе: Автореф... дис. кан. пед. наук. - Петропавловск-Камчатский: 2005. -22 c.

7. Толстых Ю.И. Критерии оценки успешности адаптации студентов-первокурсников в вузе // Известия высших учебных заведений. Поволжский регион. Гуманитарные науки, №4 (20). - 2011. - С. 137-142.

\section{The text of the article in English}

The period of professional adaptation of students in junior courses at the university is one of the most difficult. This is because this stage is a transition between the moment of choosing a profession and the beginning of work. For freshmen - future correctional teachers, professional adaptation plays a special role, because its effectiveness affects the development of a stable positive attitude towards the future profession. 
In our studies, it was noted that under the student-future teacher of special education is meant an active figure, initiative, ready to implement their own knowledge, skills. However, not always a freshman shows such qualities. As a rule, the teaching staff of the university helps self-realization of the student, creating the necessary conditions. Yu.V. Stafeeva rightly notes that human adaptation can be active or passive. So, the student chooses one or another adaptation method, and the teacher, in turn, carries out activities "to activate the internal creative forces of a growing person and develop his ability to create himself". [6, p. 12]

The author identified the following factors of pedagogical support for the adaptation of junior students to the conditions of study at the university:

- joint creative activity of teachers and students;

- system of independent work at the university;

- creation of a creative educational environment in a university;

- involvement of students in the life of the staff of the academic group;

- teaching students effective ways of educational self-organization;

- creating a favorable mutually acceptable psychological climate in the student team;

- pedagogical assistance to freshmen in gaining worthy status in the student community. [6, p. 1214]

The above factors can be considered relevant to promote the success of professional adaptation, because such pedagogical conditions contribute to the professional self-determination of students. However, these actions should be professionally directed. We believe that in the preparation of future teachers of special education as an additional factor, we can highlight the creation of conditions for self-education and self-education, as it is an integral part of pedagogical activity, in particular in working with "special" children.

A sufficient number of studies is devoted to the process of professional adaptation of students in the conditions of study at a university. Interesting work of O.R. Kokorina "Creating conditions for the adaptation of students at the university as a result of pedagogical assistance." The author sees the essence of promoting personality adaptation in the joint activities of participants in the educational process. The teacher assists the student in achieving educational goals. [4, p. 31] In our opinion, pedagogical assistance plays a leading role, including in the process of professional adaptation. It is the teacher who contributes to the disclosure of the professional orientation of the educational process.

Criteria for assessing the success of adaptation of first-year students were reflected in the works of Yu.I. Tolstoy. I.A. Varlamova and N.A. Churlyaeva presented a model of the process of adaptation 
of students of a technical university. O.A. Golubeva, T.F. Glukhova, O.N. Markina, O.V. Svetus revealed the basics of professional adaptation and developed a model of professional adaptation of students - future teachers of physical education in the process of learning at a university. Among the factors that positively affect the adaptation processes during the training period, the authors distinguish: motivational readiness for professional activity, the process of formation of the teacher's professional competence, psychological and pedagogical support. [3, p. 3] We share the opinion of the authors that the most rapid process of adapting students to new conditions is facilitated by events held at the university. The motivational component is also an essential component of adaptation to the profession at the initial stage of training.

In the model of professional and personal readiness of future teachers for corrective work with students in modern conditions, developed by E.G. Glushko, the emotional-volitional component appears. It is significant, in our opinion, because reflects a positive attitude to the teacher's profession (in particular special education), the desire to understand the "special" child, the manifestation of justice, self-control, friendliness in relations with children, patience, a sense of responsibility for the results of correctional work, the ability to self-regulation in difficult pedagogical situations, reflective willingness to assess their own capabilities. [2, p. 16]

As a result of the analysis of scientific and methodological literature, the foundations of the professional adaptation of future teachers of special education are revealed. The model we developed (Fig. 1) allows us to fully represent the process of professional adaptation of future correctional educators in the system of higher professional education at the initial stage of training.

The process of professional adaptation will be most effective if there are: motivational readiness of students for professional activity, the process of forming professional competence of a teacher of special education, pedagogical support of the educational process.

Motivational readiness manifests itself at the stage of choosing a profession and affects further professional training. At the same time, the creation of the necessary pedagogical conditions will allow students to form a stable professional orientation, and will also help them quickly adapt to their future profession at the initial stage of training. By pedagogical conditions we mean pedagogical support of students aimed at helping to master the components of a future profession, stimulating the creative activity of a person, and developing professional interest.

In the course of the study, indicators, criteria and levels for assessing the effectiveness of professional adaptation of future correctional teachers at the initial stage of study at the university were identified.

The motivational criterion includes: the presence of interest in future professional activities, the desire for professional growth and development, the willingness to acquire the competencies necessary for a future profession.

Indicators of the criterion, which we designated as personality activity, are: participation in student activism and self-government, inclusion in volunteering aimed at accompanying a child with special 
educational needs in the educational space, satisfaction with session performance, independence in educational and scientific work.

The basis of professional readiness (in junior courses) is: satisfaction with educational and professional activities, satisfaction with relationships in the teaching staff, adequate assessment of one's abilities.

We assume that as a result of meeting all conditions (with pedagogical assistance aimed at assisting in the professional self-determination of junior students; conducting activities aimed at creating a sustainable professional interest; creating conditions for self-education and self-education), the level of students' professional adaptation will increase.

A promising area of research is the analysis of the components of professional adaptation, as well as the development of tools for measuring indicators, taking into account the specifics of the professional activities of special education teachers.

\section{References}

1. Varlamova I.A. and Churlyaeva N.A. Modeling the process of adaptation of younger students to vocational education in technical universities // Personality, family and society: issues of pedagogy and psychology: Sat. Art. by mater. XXXIV Int. scientific-practical conf. No. 11 (34). Part I. - Novosibirsk: SibAK, 2013.

2. Glushko E.G. Preparing future teachers for corrective work with students in a teacher training college: Abstract ... dis. can ped sciences. - Rostov-on-Don: 2004 .- 24 p.

3. Golubeva O.A., Glukhova T.F., Markina O.N., Svetus O.V. The model of professional adaptation of students - future teachers of physical education in the process of learning at the university // Internet magazine "World of Science", 2018 No. 6, https://mir-nauki.com/ PDF/93PDMN618.pdf

4. Kokorina OR Creating conditions for the adaptation of students at a university as a result of pedagogical assistance // Pedagogy and Psychology of Professional Education, No. 3 - 2011. - P. 29-35.

5. Ryapolova Y.I. Criteria for assessing the success of professional adaptation of future teachers of special education at junior courses at the university // Scientific journal "Issues of Pedagogy", ISSN 2518-1793, No. 3 - 2019. - P. 243-247.

6. Stafeeva Yu.V. Pedagogical support for the adaptation of junior students to the conditions of study at the university: Abstract ... dis. can ped sciences. - Petropavlovsk-Kamchatsky: 2005 - $22 \mathrm{p}$.

7. Tolstykh Yu.I. Criteria for assessing the success of adaptation of first-year students in high school // News of higher educational institutions. Volga region. Humanities, No. 4 (20). - 2011 - S. 137-142. 
International Scientific and Practical Conference

PEDAGOGY AND MODERN EDUCATION

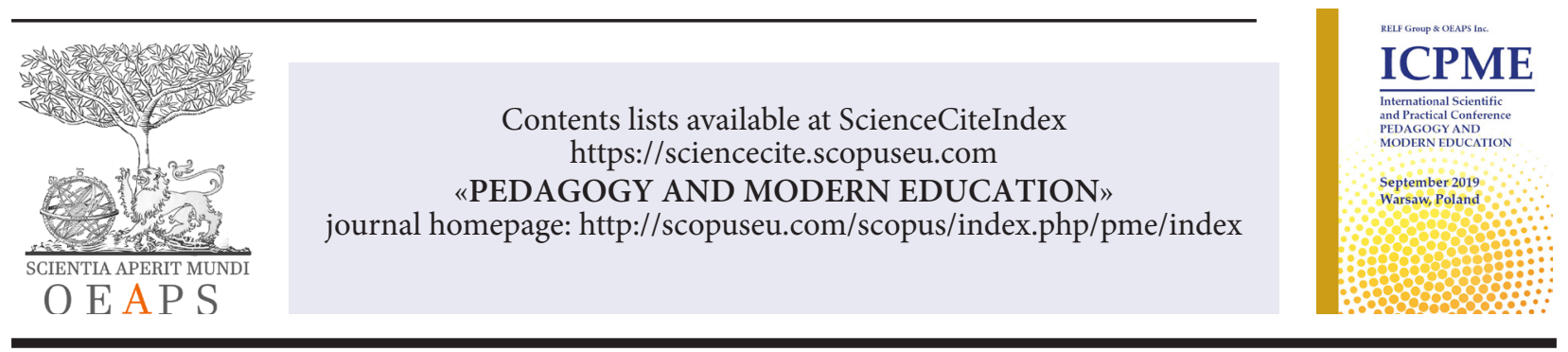

УДК 364.272

Алкоголь и подростки. Профилактика пьянства и алкоголизма среди молодёжи

Стадник Алина Владимировна

Социильный педагог МБОУ «Верхопенская СОШ» Россия Белгород

alina.stadnik@mail.ru

\title{
Alcohol and teenagers. Prevention of drinking and alcoholism among young
}

\section{Stadnik Alina Vladimirovna Social teacher MBOU “Verkhopenskaya secondary school” Russia Belgorod}

\begin{abstract}
Аннотация: в данной статье рассматривается проблема алкоголизма среди молодёжи. Подростковый алкоголизм угрожает здоровью и развитию подростков и приводит к разрушению семей. Массовость потребления спиртных напитков сегодня смещается в возрастную группу 14-15 лет. Соответственно, алкоголизм не перестаёт быть одновременно и медицинской, и нравственной проблемой. Профилактическая работа школы с подростками должна иметь две цели: передача знаний о вреде, который приносит алкоголь и наркотики человеческому организму, и воспитание представлений об опьянении как о состоянии аморальном.
\end{abstract}

Ключевые слова: подростки, алкоголизм, несовершеннолетние, средняя школа, профилактика, родители, нравственность, воспитание, здоровье, учитель.

Annotation: this article deals with the problem of alcoholism among young people. Adolescent alcoholism threatens the health and development of adolescents and leads to the destruction of families. Mass consumption of alcoholic beverages today is shifting to the age group of 14-15 years. Accordingly, alcoholism does not cease to be both a medical and a moral problem. The preventive work of the school with adolescents should have two goals: the transfer of knowledge about the harm that alcohol and drugs bring to the human body, and the education of ideas about intoxication as an immoral state.

Key words: adolescents, alcoholism, minors, high school, prevention, parents, morality, education, health, teacher.

(C) 2019 The Author. Published by OEAPS Inc. This is an open access article under the CC BY-NC-ND license (http://creativecommons.org/licenses/by-nc-nd/4.0/) 
Учёные всего мира всё громче заявляют об опасности, которая подстерегает подрастающее поколение - детей, подростков, молодёжь. Речь идёт о возрастающем размахе потребления спиртных напитков несовершеннолетними. Хотя распространённость употребления алкоголя среди мальчиков больше, чем среди девочек, однако надо заметить, что эта разница всё более сокращается.

Алкоголизация несовершеннолетних, как правило, имеет свои особенности развития. Вопервых, она зависит от возраста несовершеннолетних. Чем старше дети, тем больше их число приобщено к алкоголю, выше уровень и частого употребления алкогольных напитков. Во-вторых, важную роль в распространении алкогольной зависимости несовершеннолетних играют укоренившиеся в обществе алкогольные традиции, т.е. употребление спиртных напитков по праздникам, в связи с семейными событиями, торжествами. В-третьих, приобщают детей, подростков и молодёжь к пьянству и алкоголю чаще всего их родители и родственники.

Алкоголизация мальчиков протекает несколько иначе, чем девочек. Для неё характерны быстрые темпы развития, интенсивность. Мальчики, в среднем на два года раньше, чем их сверстницы «знакомятся» с алкоголем. К шестнадцати годам резко уменьшается число подростков, не употребляющих или редко употребляющих спиртосодержащие напитки. Как правило, большинство из них выпивают по праздникам в семейном кругу, а некоторые «с друзьями за компанию», «от нечего делать», «чтобы не отстать от товарищей» и т.д.

Рост алкоголизации среди девочек-подростков более медленный они в меньшей степени и в более позднем возрасте по сравнению с мальчиками впервые пробуют спиртное. Однако, число семнадцатилетних девушек, знакомых со вкусом алкоголя, практически равно числу мальчиков [4. с.15-18].

Губительное воздействие алкоголя на организм подростков было установлено врачами ещё в конце XIX века. В медицинской литературе конца XIX - XX века можно найти немало примеров тяжелейших отравлений детей и подростков даже ничтожными дозами алкоголя. Современные исследования позволяют обоснованно утверждать, что в теле человека нет таких органов и тканей, которые бы не поражались алкоголем.

Алкоголь - яд, и до настоящего времени неизвестно ни одного из его свойств, которое бы благоприятно влияло на клетки и ткани организма человека. Алкоголь - углеводородное химическое соединение, обладающее прямым отравляющим свойством: он расплавляет жиры, сворачивает, денатурирует белки, изменяет нормальное физиологическое течение процессов окисления и восстановления, ассимиляции.

Алкоголь остаётся ядом, как бы он ни искрился в бокалах, за какие бы красивые этикетки его ни прятали и в какие бы оригинальные сосуды его ни помещали. Составные части этого яда 
в процессе расщепления в организме вступают в различные реакции взаимодействия, при этом происходит выделении энергии. Вот почему человек, который попал в зависимость от алкоголя, готов принимать его по любому поводу и без повода. Не удовлетворяясь обычной пищей, он просит и даже требует, настаивает: «Наливай!» или сам потихоньку пьёт в одиночестве.

На ведение алкоголя организм первоначально реагирует состояние опьянения, которое Аристотель назвал «добровольным сумасшествием». Человек сам себя лишает рассудка - сначала на непродолжительное время, а затем, когда привычка переходит в болезнь, навсегда. Некоторым кажется, что алкоголь веселит, поднимает настроение. На самом же деле он просто снимает тормозящее влияние коры головного мозга, и то, что человек никогда бы не позволил себе сделать трезвым, он легко совершает в состоянии опьянении [2. с.1823].

Неоднократное или частое употребление алкоголя оказывает буквально опустошающее воздействие на психику подростка. При этом задерживается не только развитие высших форм мышления, выработка этических и нравственных категорий и эстетических понятий, но и утрачиваются уже резвившиеся способности. Подросток «тупеет» и интеллектуально, и эмоционально, и нравственно.

Второй «мишенью» алкоголя является печень. Именно здесь под воздействием ферментов происходит его расщепление. Алкоголь нарушает структуру клеток печени, приводя к перерождению её ткани. При систематическом употреблении спиртных напитков изменения в клетках печени приводят к её омертвлению - развивается цирроз печени.

Спиртные напитки «разъедают» слизистую оболочку пищевода, желудка, нарушают секрецию и состав желудочного сока, что затрудняет процесс переваривания пищи и в конечном счёте неблагоприятно сказывается на росте и развитии подростка.

Употребление спиртного вредно и для быстрорастущих в подростковом возрасте лёгких. Алкоголь и продукты его распада оказывают непосредственное токсическое воздействие на ткань бронхов, что ведёт к застойным явлениям в лёгких.

Чутко реагирует на присутствие алкоголя в организме и сердце. Изменяются как ритм, так и частота сердечных сокращений, обменные процессы в мышечных клетках сердца. Естественно, в таких условиях не может правильно, полноценно сформироваться мышечный и нервный аппарат сердца подростка.

Токсическое свойство алкоголя сказывается и на самой крови подростка. Снижается активность лейкоцитов, важного инструмента в защите организма, замедляется движение эритроцитов, несущих кислород к тканям, изменяется функция тромбоцитов, которые играют большую роль в свёртывании крови Таким образом, алкоголь ослабляет организм. 
Чем моложе организм, тем губительнее действует на него алкоголь [4. с.22-23].

Молодое поколение, которое живёт сейчас и которому предстоит жить должно быть хорошо подготовленным и физически, и духовно, и нравственно. Об этом забота всех и каждого [1. c.3-4].

Естественно, главной фигурой в школе является учитель. Поэтому, именно он обязан влиять на подростков, не дать им оступиться.

Профилактика - комплекс мероприятий, направленных на сохранение и укрепление здоровья и включающих в себя формирование здорового образа жизни, предупреждение возникновения и (или) распространения заболеваний, их раннее выявление, выявление причин и условий их возникновения и развития, а также направленных на устранение вредного влияния на здоровье человека факторов среды его обитания [5]. Как правило, в задачи школы входит первичная профилактика, которая включает в себя мероприятия направленные на предупреждение причин возникновения наркомании (рассказы о пагубном влиянии наркотиков на организм человека, возможных последствиях их употребления, формирование в сознании здорового образа жизни).

Профилактическая работа школы с подростками должна иметь две цели: передача знаний о вреде, который приносит алкоголь и наркотики человеческому организму, и воспитание представлений об опьянении как о состоянии аморальном. Иными словами, в процессе просветительской работы необходимо выделить в проблеме алкоголизма не только гигиенический, но и нравственный аспект. При этом акцент должен сместиться на нравственное значение проблемы, поскольку понятие болезни, угрозы здоровью для детей и подростков в значительной мере абстрактно, в то время как нравственные идеалы достаточно воспринимаемы и весьма ценны.

А если говорить о методической стороне этой работы, то, очевидно, систематическая антиалкогольная работа в школе должна проводиться по медико-биологическому, моральнонравственному, социально-экономическому и правовому направлениям. Особое внимание следует уделять пропаганде здорового образа жизни [1.c.124-125].

Важно, чтобы воспитательная методика была последовательной и комплексной, охватывать общеобразовательные, социальные и общественные дисциплины. Для профилактики целесообразно проводить лекции с демонстрацией кинофильмов, групповые беседы, устные журналы с участием врача, психолога, юриста [3. с.64].

Ранняя алкоголизация негативно влияет на процесс формирования подрастающей личности, препятствует реализации, многих человеческих качеств и задатков. Временной промежуток между появлением привычки к систематическим выпивкам и заболеванием тяжелым недугом 
- алкоголизмом - для взрослого составляет несколько лет, для подростка же - около года. Алкоголизм подростков в большинстве случаев с трудом поддается лечению.

Антиалкогольная пропаганда в школе не может опираться лишь на поучения о токсичности этилового спирта. Важно широко использовать в борьбе с ранней алкоголизацией знания о реальных склонностях, интересах, потребностях других психологических особенностях нынешних подростков. При этом учитывать индивидуальные особенности каждого отдельного ученика. В каждом учебном заведении разрабатывается общая комплексная программа противоалкогольной деятельности. Она должна охватывать всех учащихся: от первого до выпускного класса, но наиболее активно воздействовать на детей младших классов [3. с.67]. Цель противоалкогольного воспитания состоит в том, чтобы вооружить учащихся минимумом научных знаний об отрицательном воздействии алкоголя и других наркотических веществ на организм человека с биологической, гигиенической, медицинской и социальной точек зрения, сформировать в школьных и классных коллективах, в семьях учащихся нетерпимое отношение к пьянству и психологическую сопротивляемость ему [1. с.126]. Желательно информацию о вреде алкоголя включать в содержание уроков обществоведения, истории, литературы, биологии, химии, других предметов, дискуссии о здоровом образе жизни, сценарии развлекательных мероприятий и т.П. При этом целесообразно не столько привлекать внимание учеников к негативному влиянию алкоголя на жизнедеятельность человека, сколько подчеркивать безнравственность пьянства, преимущества трезвого образа жизни [3. с.67].

Медико-биологические аспекты профилактики алкоголизма среди школьников заключаются в том, чтобы раскрыть механизм влияния алкоголя и наркотических веществ на организм человека, прежде всего на организм подростков и юношей, на организм будущей матери, на потомство.

Что касается морально-нравственного направления в антиалкогольном воспитании и пропаганде, то здесь следует обратить внимание учащихся на безнравственность пьянства, алкоголизма и наркомании, на моральный урон, который наносят пьяницы или иным образом пристрастившиеся к одурманивающим средствам окружающим людям, родным и близким. Следует убедительно и аргументировано опровергнуть бытующее у определенной категории подростков представление о том, что употребление алкоголя - признак взрослости и возмужания. Нужно научить школьников уметь проводить свободное время, организовать так досуг, чтобы исключить всякую потребность времяпрепровождения с употреблением спиртных напитков или дурманящих средств.

Задача правового воспитания - разъяснить учащимся сущность действующего антиалкогольного и антинаркотического законодательства, ознакомить их с видами и 
мерами правовой ответственности. Социально-экономическое направление включает наглядный показ того вреда, который приносит употребление алкоголя и наркотиков здоровью населения, экономике страны в целом [1. с.125,126] (все данные направления антиалкогольного воспитания отражаются в программе формирования культуры здорового и безопасного образа жизни и плане работы МБОУ «Верхопенская СОШ» по профилактике алкоголизма среди учащихся). Программа сформирована с учётом факторов, оказывающих существенное влияние на состояние здоровья детей: неблагоприятные социальные, экономические и экологические условия; внутришкольные факторы риска, которые приводят к дальнейшему ухудшению здоровья детей и подростков от первого к последнему году обучения; временной разрыв между педагогическим воздействием и результатом, который может быть значительным, достигая нескольких лет, и тем самым между начальным и существенным проявлением неблагополучных популяционных сдвигов в здоровье детей и подростков, и всего населения страны в целом; активно формируемые в младшем школьном возрасте комплексы знаний, установок, правил поведения, привычек; особенности отношения обучающихся младшего школьного возраста ксвоему здоровью, существенно отличающиеся от таковых у взрослых, что связано с отсутствием у детей опыта «нездоровья» (за исключением детей с серьёзными хроническими заболеваниями) и восприятием ребёнком состояния болезни главным образом как ограничения свободы (необходимость лежать в постели, болезненные уколы), неспособностью прогнозировать последствия своего отношения к здоровью, что обусловливает, в свою очередь, невосприятие ребёнком деятельности, связанной с укреплением здоровья и профилактикой его нарушений, как актуальной и значимой (ребёнок всегда стремится к удовлетворению своих актуальных потребностей, он не знает, что такое будущее, и поэтому ни за что не пожертвует настоящим ради будущего и будет сопротивляться невозможности осуществления своих желаний).

Надо заметить, что при выборе стратегии воспитания культуры здоровья необходимо, учитывая психологические и психофизиологические характеристики возраста, опираться на зону актуального развития, исходя из того, что формирование ценности здоровья и здорового образа жизни - необходимый и обязательный компонент здоровьесберегающей работы образовательного учреждения, требующий соответствующей здоровьесберегающей организации всей жизни образовательного учреждения, включая её инфраструктуру, создание благоприятного психологического климата, обеспечение рациональной организации учебного процесса, эффективной физкультурно-оздоровительной работы, рационального питания [6].

Детям младшего школьного возраста, как известно, свойственно подражательное поведение, поэтому правильная ориентация их в отношении алкоголя в значительной степени определяется их ближайшим окружением. В задачу педагогов, родителей, медицинских работников на этом этапе входит воспитание у детей отрицательного отношения к алкоголю в самом общем виде, без лишней детализации. Поэтому антиалкогольную работу с учащимися 
начальных классов рекомендуется проводить в форме бесед продолжительностью не более 15-20 минут. Вести их должен преимущественно учитель, хотя в некоторых случаях возможно привлечение врачей. Необходимо сформировать у этой категории учащихся представления о здоровом образе жизни, о правильной организации отдыха, в младших классах необходимо избегать прямолинейности в постановке проблемы.

Имеет свою специфику антиалкогольное воспитание школьников средних классов. Возраст с 11 до 14 лет, так называемый подростковый или средний школьный, пожалуй, один из самых сложных в жизни человека. Именно в этот период, как известно, происходит резкий скачок роста и развития всех органов, а системная перестройка сопровождается перестройкой сознания. Следовательно, на этом этапе особенно важно закрепить у школьников антиалкогольные установки, расширяя и углубляя их знание о свойствах, действии на организм, возможных последствиях употребления алкоголя и т. д.

В старшем возрасте (15-17 лет) с наступлением периода половой зрелости в основном завершается психическое и качественное формирование личности. Именно в этом возрасте достаточно активно складывается мировоззрение и вырабатывается осознанное отношение к жизни. Становятся более конкретными и прочными интеллектуальные и общественные интересы, однако ранимость, неустойчивость, лабильность школьников этой возрастной группы обусловливает всевозможные стрессовые ситуации, которые нередко могут спровоцировать разного рода негативное поведение, в том числе употребление спиртных напитков. Проведение работы по антиалкогольному воспитанию в этом возрасте сопряжено с известными трудностями ещё и потому, что отношение к употреблению алкоголя уже, как правило, сформировано. Определенная, скорее всего большая, часть учащихся старших классов скептически настроена к мероприятиям антиалкогольной направленности. Нередко встречаются и такие, которые морально и психологически смирились с пьянством взрослых и считают это нормальным явлением.

Антиалкогольное воспитание и антиалкогольная пропаганда, направленные на несовершеннолетних и на молодёжную аудиторию, по существу, не различаются. Основные аспекты их состоят в том, чтобы помочь подрастающему поколению осознать, что даже незначительные дозы алкоголя или других одурманивающих средств - сильнейший катализатор противоправных поступков. Они должны знать об опасности вовлечения в противоправную деятельность из-за привычки к алкоголю или наркотическим веществам, должны сознавать ответственность за будущее страны [1. с.173].

\section{Список литературы}

1. Анисимов Л. Н. Профилактика пьянства, алкоголизма и наркомании среди молодёжи. / Л.Н. Анисимов. — М.: Юрид. лит., 1988. - 176 с.

2. Гарницкий С.П. Алкоголь, табак, наркотики и здоровье подростков. / С.П. Гарницкий. - К.: Здоровье, 1988. - 32 с.: ил. 
3. Перешеина Н.В., Заостровцева М.Н. Девиантный школьник: Профилактика и коррекция отклонений. / Н.В. Перешеина, М.Н. Заостровцева - М.: ТЦ Сфера, 2006. - 192 с. - (Библиотека практического психолога).

4. Скворцова Е.С. Алкоголь, женщины, подростки. / Е.С. Скворцова. - М.: Медицина, 1988. - 40c.

5. Федеральный закон Российской Федерации от 21 ноября 2011 г. N 323-Ф3 «Об основах охраны здоровья граждан в Российской Федерации» - [Электронный ресурс]. - http:// www.rg.ru/2011/11/23/zdorovie-dok.html

6. http://vrhpschool.narod.ru

\section{The text of the article in English}

Scientists all over the world are increasingly declaring the danger that lies in wait for the younger generation - children, adolescents, youth. We are talking about the growing scope of alcohol consumption by minors. Although the prevalence of alcohol consumption among boys is greater than among girls, it should be noted that this difference is becoming more and more reduced.

Alcoholization of minors, as a rule, has its own developmental features. Firstly, it depends on the age of minors. The older the children, the more their number is attached to alcohol, the higher the level and frequent use of alcoholic beverages. Secondly, an important role in the spread of alcohol addiction of minors is played by alcoholic traditions rooted in society, i.e. drinking alcohol on holidays, in connection with family events, celebrations. Thirdly, children, adolescents and youth are introduced to drinking and alcohol most often by their parents and relatives.

Alcoholization of boys proceeds somewhat differently than girls. It is characterized by rapid development, intensity. Boys, on average, two years earlier than their peers "get acquainted" with alcohol. By the age of sixteen, the number of adolescents who do not drink or rarely drink alcohol is sharply reduced. As a rule, most of them drink on holidays in the family circle, and some "with friends for company", "nothing to do", "in order to keep up with comrades", etc.

The increase in alcoholism among teenage girls is slower to a lesser extent and at a later age compared with boys for the first time try alcohol. However, the number of seventeen-year-old girls familiar with the taste of alcohol is almost equal to the number of boys [4. p.15-18].

The detrimental effect of alcohol on the body of adolescents was established by doctors at the end of the XIX century. In the medical literature of the late XIX - XX centuries, you can find many examples of the most severe poisoning of children and adolescents, even with negligible doses of alcohol. Modern research allows us to reasonably argue that in the human body there are no organs and tissues that would not be affected by alcohol. 
Alcohol is a poison, and to date no one of its properties is known that would favorably affect the cells and tissues of the human body. Alcohol is a hydrocarbon chemical compound with a direct poisoning property: it melts fats, coagulates, denatures proteins, and alters the normal physiological course of oxidation and reduction processes, assimilation.

Alcohol remains poison, no matter how it sparkles in the glasses, for whatever beautiful labels it is hidden and in whatever original vessels it is placed. The components of this poison in the process of splitting in the body enter into various reactions of interaction, with the release of energy. That is why a person who has become addicted to alcohol is ready to take it for any reason and for no reason. Not satisfied with the usual food, he asks and even demands, insists: "Pour it!" Or he slowly drinks alone.

The organism is initially affected by alcohol intoxication, which Aristotle called "voluntary madness." Man himself is deprived of reason - first for a short time, and then, when the habit turns into a disease, - forever. Some people think that alcohol is fun, uplifting. In fact, it simply removes the inhibitory effect of the cerebral cortex, and that which a person would never allow himself to be sober, he easily does when intoxicated [2. p. 18-23].

Repeated or frequent use of alcohol has a literally devastating effect on the psyche of a teenager. At the same time, not only the development of higher forms of thinking, the development of ethical and moral categories and aesthetic concepts is delayed, but already frolicing abilities are lost. A teenager is "dull" intellectually, emotionally, and morally.

The second "target" of alcohol is the liver. It is here that, under the influence of enzymes, its cleavage occurs. Alcohol violates the structure of liver cells, leading to the degeneration of its tissue. With the systematic use of alcoholic beverages, changes in the liver cells lead to its necrosis - liver cirrhosis develops.

Alcohol "corrodes" the mucous membrane of the esophagus, stomach, disrupts the secretion and composition of the gastric juice, which complicates the process of digesting food and ultimately adversely affects the growth and development of the adolescent.

Drinking alcohol is also harmful to lungs that are rapidly growing during adolescence. Alcohol and its decay products have a direct toxic effect on the tissue of the bronchi, which leads to congestion in the lungs.

It is sensitive to the presence of alcohol in the body and heart. Both the rhythm and the heart rate, metabolic processes in the muscle cells of the heart change. Naturally, under such conditions, the muscle and nervous apparatus of the adolescent's heart cannot form properly, fully.

The toxic property of alcohol affects the blood of a teenager. The activity of leukocytes, an important tool in protecting the body, decreases, the movement of red blood cells that carry oxygen to the tissues slows down, the function of platelets, which play an important role in blood coagulation, 
changes. Thus, alcohol weakens the body. The younger the body, the more destructive is the effect of alcohol on it [4. p.22-23].

The young generation who lives now and who have to live should be well prepared both physically, spiritually, and morally. This is the concern of everyone and everyone [1. p. 3-4].

Naturally, the main figure in the school is the teacher. Therefore, it is he who is obliged to influence teenagers, not to let them stumble.

Prevention - a set of measures aimed at maintaining and strengthening health and including the formation of a healthy lifestyle, preventing the onset and (or) spread of diseases, their early detection, identifying the causes and conditions of their occurrence and development, as well as aimed at eliminating the harmful effects on human health environmental factors [5]. As a rule, the primary tasks of the school include primary prevention, which includes measures aimed at preventing the causes of drug addiction (stories about the harmful effects of drugs on the human body, the possible consequences of their use, the formation of a healthy lifestyle in the mind).

Preventive school work with adolescents should have two goals: the transfer of knowledge about the harm that alcohol and drugs bring to the human body, and the education of ideas about intoxication as an immoral state. In other words, in the process of educational work, it is necessary to highlight not only the hygienic, but also the moral aspect in the problem of alcoholism. At the same time, the emphasis should shift to the moral significance of the problem, since the concept of illness, a threat to health for children and adolescents is largely abstract, while moral ideals are quite perceptible and very valuable.

And if we talk about the methodological side of this work, then, obviously, systematic anti-alcohol work in the school should be carried out in biomedical, moral, social, economic and legal directions. Particular attention should be paid to promoting a healthy lifestyle [1.p.124-125].

It is important that the educational methodology be consistent and comprehensive, covering general educational, social and social disciplines. For prevention, it is advisable to conduct lectures with demonstration of films, group discussions, oral magazines with the participation of a doctor, psychologist, lawyer [3. p.64].

Early alcoholization negatively affects the formation of a growing personality, and impedes the realization of many human qualities and inclinations. The time interval between the emergence of a habit of systematic drinking and a serious illness - alcoholism - for an adult is several years, for a teenager - about a year. Adolescent alcoholism in most cases is difficult to treat.

School anti-alcohol propaganda cannot rely solely on teachings on the toxicity of ethyl alcohol. It is important to widely use in the fight against early alcoholization knowledge about the real 
inclinations, interests, needs of other psychological characteristics of today's adolescents. In doing so, take into account the individual characteristics of each individual student. In each educational institution, a general comprehensive program of anti-alcohol activities is being developed. It should cover all students: from first to graduation, but most actively affect primary school children [3. p.67]. The purpose of anti-alcohol education is to equip students with a minimum of scientific knowledge about the negative effects of alcohol and other narcotic substances on the human body from a biological, hygienic, medical and social point of view, to form intolerant attitudes towards drunkenness in school and classrooms, in families of students psychological resistance to him [1. p.126]. It is advisable to include information on the dangers of alcohol in the content of social studies, history, literature, biology, chemistry, other subjects, discussions about a healthy lifestyle, entertainment scenarios, etc. In this case, it is advisable not only to draw the attention of students to the negative impact of alcohol on human life, but to emphasize the immorality of drunkenness, the benefits of a sober lifestyle [3. p.67].

Biomedical aspects of the prevention of alcoholism among schoolchildren are to reveal the mechanism of the influence of alcohol and drugs on the human body, especially on the body of adolescents and youths, on the body of the expectant mother, on the offspring.

As for the moral direction in anti-alcohol education and propaganda, here we should draw the attention of students to the immorality of drunkenness, alcoholism and drug addiction, to the moral damage caused by drunkards or otherwise addicted to stupefying to surrounding people, relatives and friends. It is necessary to convincingly and reasonably refute the notion prevailing in a certain category of adolescents that the use of alcohol is a sign of adulthood and maturity. It is necessary to teach schoolchildren to be able to spend free time, to organize leisure activities in such a way as to exclude any need for spending time with the use of alcoholic beverages or intoxicating agents.

The task of legal education is to explain to students the essence of the existing anti-alcohol and anti-drug legislation, to familiarize them with the types and measures of legal responsibility. The socio-economic direction includes a visual demonstration of the harm that alcohol and drugs cause to the health of the population, the country's economy as a whole [1. p.125,126] (all these directions of anti-alcohol education are reflected in the program for the formation of a healthy and safe lifestyle culture and the work plan of MBOU "Verkhopenskaya Secondary School" for the prevention of alcoholism among students). The program is formed taking into account factors that have a significant impact on children's health: adverse social, economic and environmental conditions; Intra-school risk factors that lead to further deterioration in the health of children and adolescents from the first to the last year of schooling; the time gap between the pedagogical impact and the result, which can be significant, reaching several years, and thus between the initial and significant manifestation of dysfunctional population shifts in the health of children and adolescents, and the entire population of the country as a whole; complexes of knowledge, attitudes, rules of behavior, habits actively formed at primary school age; peculiarities of the attitude of primary 
school students to their health, which significantly differ from those in adults, due to the lack of children's experience of "unhealth" (with the exception of children with serious chronic diseases) and the child's perception of the state of the disease mainly as a restriction of freedom (the need to lie in bed, painful injections), inability to predict the consequences of their attitude to health, which, in turn, determines the child's non-perception of activities related to strengthening health and the prevention of its disorders as relevant and significant (the child always strives to meet his current needs, he does not know what the future is, and therefore will not sacrifice the present for the future and will resist the impossibility of fulfilling his desires).

It should be noted that when choosing a strategy to foster a culture of health, it is necessary, taking into account the psychological and psychophysiological characteristics of age, to rely on the zone of actual development, proceeding from the fact that the formation of the value of health and a healthy lifestyle is a necessary and indispensable component of the health-saving work of the educational institution, requiring appropriate health-saving organization of the entire life of the educational institution, including its infrastructure, the creation of a favorable psychological climate, ensuring the rational organization of the educational process, effective physical fitness work, rational nutrition [6].

It is well known that children of primary school age have a characteristic of imitative behavior, therefore, their correct orientation in relation to alcohol is largely determined by their immediate environment. The task of teachers, parents, medical workers at this stage is to educate children in a negative attitude to alcohol in the most general form, without too much detail. Therefore, it is recommended that anti-alcohol work with primary school students be carried out in the form of conversations lasting no more than 15-20 minutes. Mostly the teacher should lead them, although in some cases doctors may be involved. It is necessary to form in this category of students ideas about a healthy lifestyle, about the correct organization of rest, in the elementary grades it is necessary to avoid straightforwardness in posing the problem.

Has its own specifics anti-alcohol education of middle school students. The age from 11 to 14 years, the so-called teenage or secondary school, is perhaps one of the most difficult in human life. It is during this period, as you know, that there is a sharp jump in the growth and development of all organs, and systemic restructuring is accompanied by a restructuring of consciousness. Therefore, at this stage it is especially important to consolidate anti-alcohol installations in schoolchildren, expanding and deepening their knowledge about the properties, effects on the body, possible consequences of drinking alcohol, etc.

At an older age (15-17 years) with the onset of puberty, mental and qualitative personality formation ends. It is at this age that the worldview is quite active and a conscious attitude to life is developed. Intellectual and public interests become more specific and durable, however, the vulnerability, instability, and lability of schoolchildren of this age group causes all kinds of stressful situations, 
which can often provoke various kinds of negative behavior, including the use of alcohol. Carrying out work on anti-alcohol education at this age is fraught with well-known difficulties also because the attitude to drinking is, as a rule, already formed. A certain, most likely large, part of high school students is skeptical about anti-alcohol activities. Often there are those who morally and psychologically reconciled with the drunkenness of adults and consider this a normal phenomenon.

Anti-alcohol education and anti-alcohol propaganda aimed at minors and youth audiences are essentially the same. The main aspects of them are to help the younger generation realize that even small doses of alcohol or other intoxicants are a powerful catalyst for illegal acts. They should be aware of the dangers of involvement in illegal activities due to the habit of alcohol or drugs, they should be aware of the responsibility for the future of the country [1.p.173].

\section{References}

1. Anisimov L. N. Prevention of drunkenness, alcoholism and drug addiction among young people. / L.N. Anisimov. - M .: Yurid. lit., 1988 .-- 176 p.

2. Garnitsky S.P. Alcohol, tobacco, drugs and adolescent health. / S.P. Garnitsky. - K .: Health, 1988. - 32 p.: Ill.

3. Peresheina N.V., Zaostrovtseva M.N. Deviant schoolboy: Prevention and correction of deviations. / N.V. Pereshein, M.N. Zaostrovtseva - M.: SC Sphere, 2006 .-- 192 p. - (Library of the practical psychologist).

4. Skvortsova E.S. Alcohol, women, teens. / E.S. Skvortsova. - M .: Medicine, 1988 .-- 40s.

5. Federal Law of the Russian Federation of November 21, 2011 N 323-Ф3 "On the Basics of Protecting Citizens' Health in the Russian Federation” - [Electronic resource] - http://www. rg.ru/2011/11/23/zdorovie-dok.html

6. http://vrhpschool.narod.ru 
International Scientific and Practical Conference

PEDAGOGY AND MODERN EDUCATION

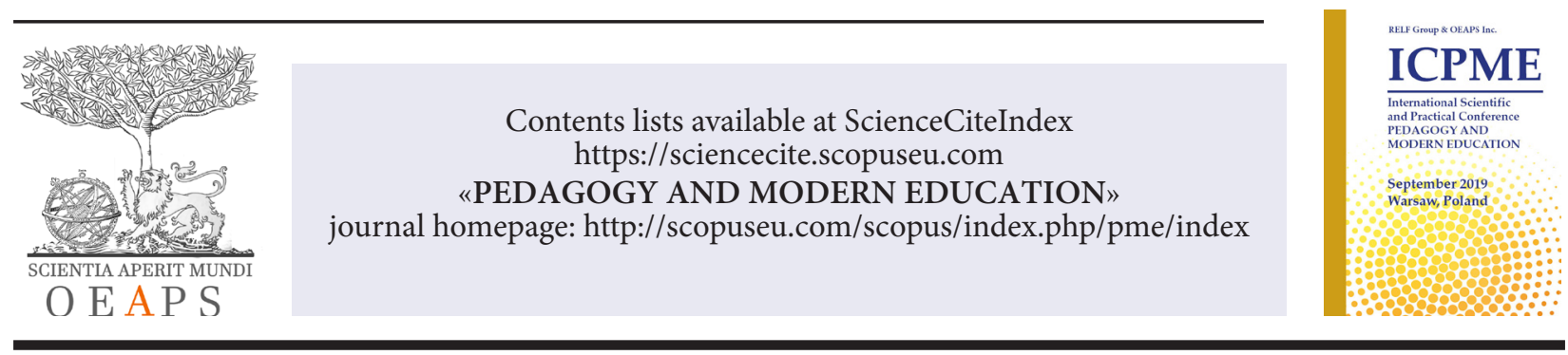

УДК 37.017.4

\section{Возможности школьного музея в формировании гражданственности и гражданской активности школьников}

Гарифуллина Виктория Викторовна учитель истории и обществознания выстей квалификаиионной категории, руководитель музея МБОУ «Гимназия №93», Россия, г. Казань garifullinavv@mail.ru

\section{Opportunities of school museums in raising a sense of citizenship and civil activity of school students}

Garifullina Victoria Viktorovna teacher of history and social science of the highest qualification category, head of the museum of the gymnasium No. 93, Russia, Kazan

Аннотация: Школьные музеи имеют большой потенциал для формирования гражданственности и гражданской активности школьников. Школьный музей - это и форма деятельности, и средство воспитания, и источник для самореализации.

Abstract: School museums have a great potential in raising a sense of civic consciousness and civil activity of school students. School museums are not only a form activities but also means of upbringing and a source of selfrealization.

Ключевые слова (key words): школьный музей, воспитание, личность, гражданственность, гражданская активность,school museum, upbringing, personality, citizenship, civic consciousness, civil activity.

Школа - это мастерская, где формируется мысль подрастающего поколения, надо крепко держать ее в руках, если не хочешь выпустить из рук будущее.

А. Барбюс

(c) 2019 The Author. Published by OEAPS Inc. This is an open access article under the CC BY-NC-ND license (http://creativecommons.org/licenses/by-nc-nd/4.0/) 
International Scientific and Practical Conference

PEDAGOGY AND MODERN EDUCATION

Известный социолог и педагог Питирим Сорокин считал, что семья - это первая мастерская, которая формирует человеческую личность, а продолжить эту работу должна школа. Именно в школе ребенок приобретает знания, осваивает навыки, учится выстраивать отношения, начинает понимать, что ждет его во взрослой жизни. Школа в ответе перед обществом за то, какие ориентиры предложит своим ученикам, в какую сторону направит их мысли и энергию. Главная задача школы, как социального института, вырастить достойного гражданина своего Отечества.

Какой должна быть школа, чтобы её выпускники могли вслед за великим ученым, лауреатом Нобелевской премии И. П. Павловом произнести: «Вся моя деятельность, хотя бы по сути своей интернациональная, связана с достоинством и интересами Родины» [3, с. 312]? Может ли учебное заведение оказывать влияние на формирование гражданственности и патриотизма у школьников? Есть ли у школы ресурсы для выполнения этой задачи?

Для школьного учителя ответ очевиден и он положителен. Вся учебно-воспитательная деятельность: уроки, внеклассные мероприятия, кружки - все должно учить ответственному и вдумчивому отношению к свободе и правопорядку, воспитывать юного человека в уважении к истории и культуре родной страны. Должно способствовать воспитанию гражданственности -

нравственного качества личности, определяющего сознательное и активное выполнение гражданских обязанностей и долга перед государством, обществом, народом [4].

Наиболее полно и целенаправленно могут и должны действовать в этом направлении школьные музеи, что подтверждается рядом нормативно-правовых документов. ФГОС основного общего образования неоднократно подчеркивает необходимость учета региональных, национальных и этнокультурных особенностей народов Российской Федерации при организации работы образовательных учреждений [5]. В Государственной программе «Патриотическое воспитание граждан Российской Федерации на 2016-2020 годы» [1] школьным музеям отведена особая роль. В первую очередь, именно краеведческая.

Следовательно, государство возлагает на музей, действующий в стенах школы, использующий разные формы и методы работы, особые функции. Школьный музей должен расширить кругозор учащегося, познакомить ученика с краеведческой и исследовательской деятельностью, научить основам некоторых профессий, сформировать его гражданское самосознание, укрепить чувство любви к малой и большой Родине, сформировать осознанный патриотизм.

Такие педагоги-исследователи, как М.Ю. Юхневич, В.Е. Туманова, Б.А. Столяров, считают, что именно школьный музей может воспитывать настоящий, реальный, а не показной патриотизм. И.А. Дюмина называет школьный музей не только формой организации учебнопознавательной деятельности, но и средством духовного воспитания[2], что в очередной раз доказывает значимость музейной педагогики. 
Еще одним доказательством в этом может послужить опыт казанской гимназии №93. В гимназии много лет функционирует два школьных музея. Один из них связан с жизнью и творчеством великого татарского композитора Назиба Гаязовича Жиганова, а другой называется «Музей тимуровского движения имени А. П. Гайдара». У каждого из них своя история, познавательная и поучительная.

В разные периоды истории школьные музеи нашей страны повсеместно переживали разные ситуации, в их развитие наблюдались периоды подъема и спада. Было время, когда в школьных музеях видели главнейший резерв для развития государственных музеев. И было время, когда с некоторыми музеями боролись как с хранителями отжившей идеологии...

Л.Н. Толстому принадлежат следующие строки: «Страна, забывшая свою культуру, историю, традиции и национальных героев - обречена на вымирание». Именно с этих строк начинается в нашей гимназии знакомство с музеем А.П. Гайдара, который был открыт в 1968 году. На протяжении многих лет школа №93 являлась Всероссийским центром тимуровского движения. В 70-е годы на базе школы неоднократно проводились Всероссийские конференции и слеты активистов тимуровского движения. А потом в стране начинаются известные события, приведшие в последствие к распаду СССР, отторжению его идеологического наследия, ревизии исторических фактов и событий, свержению с пьедесталов героев советского времени.

Коллектив гимназии, понимая свою ответственность перед подрастающим поколением за сохранение исторической правды, за воспитание их ответственными и толерантными гражданами нашей Родины сделали все возможное для сохранения музея.

Сегодня этот музей - музей истории тимуровского движения. Его экспозиция включает в себя разделы не только о жизни самого Гайдара и его литературном наследии, но и о героических страницах Великой Отечественной войны и знаковых событиях современной истории. Силами учащихся и педагогов созданы стенды о фронтовиках - жителях нашего микрорайона, об учителях - участниках войны, об ученике Фархаде Акмаеве - участнике Афганской войны. Собраны материалы, вошедшие в проект «Музей в чемодане». Бережно хранятся сочинения-воспоминания и фотографии бывших пионеров о своем участие в пионерском и тимуровском движении. Продолжает пополняться музейная мини-библиотека книг Гайдара на языках народов мира, а также книг о самом Гайдаре и о войне. Проводятся тематические экскурсии, конкурсы чтецов, открытые уроки, праздники книг-юбиляров, кинолектории по произведениям Гайдара. Ежегодно учениками пишутся исследовательские и творческие работы по темам: «Их именами названы улицы Казани», «Города-герои», «Города воинской славы», «Труженикам тыла слава!», «История страны в произведениях А.П. Гайдара», «Этих дней не смолкнет слава». Оказывается помощь престарелым жителям микрорайона. Созданы все условия для гражданской активности школьников. 
International Scientific and Practical Conference

PEDAGOGY AND MODERN EDUCATION

История создание музея Жиганова связано с празднованием 90-летия со дня рождения композитора. Однако факт открытия в 2001 году и существования в стенах гимназии с русским этнокультурным компонентом музея великого татарского композитора Назиба Гаязовича Жиганова всегда вызывает неподдельное удивление у всех пришедших в этот музей.

Музей возник при деятельном участии вдовы композитора Н.И. Жигановой по инициативе педагогов гимназии. Наибольший вклад в открытие музея вложила Э. В. Дугина. Дружба двух этих женщин сделала новый школьный музей достойным памятником великому музыканту.

Кроме того, в стенах гимназии и в тесном сотрудничестве с ней действует детская музыкальная школа № 23, в которой несколько лет после выхода на пенсию работал профессор казанской консерватории Низамутдинов Шамиль Гильмутдинович, один из ведущих педагогов страны, музыкант высокого класса, человек лично хорошо знавший Жиганова. Из его личного архива в дар школьному музею перешли музыкальные альбомы, буклеты, программки, фотографии, - все, что связано с именем Жиганова.

При активном участии школьников была создана экспозиция музея, начата работа по изучению наследия композитора, написанию исследовательских работ, составлению экскурсионных маршрутов. Здесь изучают музыку и ее создателей. Здесь пишут сочинения, рисуют картины, создают фильмы. Ученики успешно выступают со своими работами на конкурсах и конференциях, что позволяет им проявлять не только знания и навыки, но и демонстрировать сформированность таких качеств, как ответственность, толерантность, гражданственность.

Большое влияние на развитие школьного музея и его активной деятельности принадлежит сотрудникам городского музея-квартиры Н.Г. Жиганова - Яковлевой Л. А., Егорову А. Г.

Тематические лектории, дни музыки, дни памяти, дни творчества, встречи с музыкантами, конкурсы сочинений и проектов - вот масштаб для общественной активности учащихся.

В школьных музеях силами учеников создается необходимая документация, проводится учет имеющихся основных и вспомогательных фондов, осваиваются основы музейных профессий.

Музеи гимназии для школьников - это живая память и социокультурные ценности, это возможность прикоснуться к традициям и принять деятельное участие в их усвоении, сохранении и передачи следующим поколениям. Это история и творчество, это социализация и профориентация, это патриотизм и гражданская самоидентификация. 
Обучая, воспитывая и развивая, школьный музей способствует становлению зрелой личности, формированию гражданской активности и гражданственности.

\section{Список литературы}

1. Государственная программа «Патриотическое воспитание граждан Российской Федерации на 2016-2020 годы» [Электронный ресурс] - URL:http://static.government.ru/media/ files/8qqYUwwzHUxzVkH1jsKAErrx2dE4q0ws.pdf - (Дата обращения: 12.03.2019).

2. Дюмина И.А. Патриотическое воспитание учащихся средствами школьного музея // Человек и образование. 2012. № 4 (33). С. 49-52.

3. Обществознание. 11класс: учеб. для общеобразоват. учреждений: профил. уровень/ Л.Н. Боголюбов и др. - М.: Просвещение, 2010. - с.312.

4. Педагогический словарь. - М.: Академия. Г. М. Коджаспирова, А. Ю. Коджаспиров. 2005.

5. Федеральный государственный образовательный стандарт основного общего образования [Электронный ресурс] - URL: http://window.edu.ru/resource/768/72768/files/FGOS_OO.pdf (Дата обращения: 12.03.2019).

\section{The text of the article in English}

A school is a workshop where the thought of the younger generation is formed, you need to hold it tightly in your hands, if you do not want to let go of the future.

A. Barbus

The famous sociologist and teacher Pitirim Sorokin believed that the family is the first workshop that shapes the human personality, and the school should continue this work. It is in school that a child acquires knowledge, learns skills, learns to build relationships, begins to understand what awaits him in adulthood. The school is responsible to society for what guidelines it will offer its students, in which direction they will direct their thoughts and energy. The main task of the school, as a social institution, is to raise a worthy citizen of its Fatherland.

What should a school be like so that its graduates, after the great scientist, Nobel Prize laureate IP Pavlov, could say: "All my activity, even if inherently international, is connected with the dignity and interests of the motherland" [3, p. 312]? Can an educational institution influence the formation of citizenship and patriotism among schoolchildren? Does the school have the resources to complete this task?

For the school teacher, the answer is obvious and positive. All educational activities: lessons, extracurricular activities, circles - everything should teach a responsible and thoughtful attitude to freedom and the rule of law, to educate a young man in respect for the history and culture of his native country. It should contribute to the education of citizenship - the

moral quality of the individual, which determines the conscious and active fulfillment of civic duties and obligations to the state, society, people [4]. 
School museums can and should act in this direction most fully and purposefully, as evidenced by a number of legal documents. GEF of basic general education has repeatedly emphasized the need to take into account regional, national and ethnocultural characteristics of the peoples of the Russian Federation when organizing the work of educational institutions [5]. School museums have a special role in the State Program "Patriotic Education of Citizens of the Russian Federation for 2016-2020" [1]. First of all, it is local history.

Consequently, the state assigns special functions to the museum, operating within the walls of the school, using various forms and methods of work. The school museum should expand the horizons of the student, introduce the student to the study of local lore and research, teach the basics of some professions, form his civic identity, strengthen the feeling of love for the small and large Motherland, and form conscious patriotism.

Such research teachers as M.Yu. Yukhnevich, V.E. Tumanova, B.A. Stolyarov, it is believed that it is the school museum that can bring up real, real, and not ostentatious patriotism. I.A. Dyumin calls the school museum not only a form of organization of educational and cognitive activity, but also a means of spiritual education [2], which once again proves the importance of museum pedagogy.

Another proof of this may be the experience of Kazan gymnasium No. 93. There are two school museums in the gymnasium for many years. One of them is associated with the life and work of the great Tatar composer Nazib Gayazovich Zhiganov, and the other is called the A. P. Gaidar Museum of the Timurov Movement. Each of them has its own story, informative and instructive.

At different periods of history, school museums of our country everywhere experienced different situations; during their development, periods of ups and downs were observed. There was a time when school museums saw the main reserve for the development of state museums. And there was a time when they fought with some museums as guardians of an outdated ideology ...

L.N. The following lines belong to Tolstoy: "A country that has forgotten its culture, history, traditions and national heroes is doomed to extinction." It is from these lines that the acquaintance with the A.P. Museum begins in our gymnasium. Gaidar, which was opened in 1968. For many years, school number 93 was the All-Russian center of the Timurov movement. In the 70s, the AllRussian conferences and rallies of activists of the Timurov movement were repeatedly held at the school. And then, well-known events begin in the country, which led to the collapse of the USSR, the rejection of its ideological heritage, the revision of historical facts and events, the overthrow of the heroes of the Soviet era from the pedestals.

The gymnasium staff, understanding their responsibility to the younger generation for preserving the historical truth, for educating them with responsible and tolerant citizens of our country, did everything possible to preserve the museum. 
Today this museum is a museum of the history of the Timur movement. Its exposition includes sections not only about the life of Gaidar himself and his literary heritage, but also about the heroic pages of the Great Patriotic War and the landmark events of modern history.

Through the efforts of students and teachers, stands were created about front-line soldiers - residents of our neighborhood, about teachers - participants of the war, about a student Farhad Akmaev - a participant in the Afghan war. The materials included in the project "Museum in a Suitcase" were collected. Memoirs and photographs of former pioneers about his participation in the pioneer and Timurov movement are carefully preserved. The museum mini-library of Gaidar's books in the languages of the peoples of the world, as well as books about Gaidar himself and about the war, continues to grow. Thematic tours, reader contests, open lessons, book festivals, film lectures based on Gaidar's works are held. Each year, students write research and creative works on the topics: "Kazan Street", "Hero Cities", "Cities of Military Glory", "Glory to the Workers of the Rear!", "History of the Country in the Works of A.P. Gaidar "," Glory will not cease these days. "Helping the elderly residents of the neighborhood. All conditions have been created for the civic activity of schoolchildren.

The history of the creation of the Zhiganov Museum is associated with the celebration of the 90th anniversary of the composer's birth. However, the fact of the opening in 2001 and the existence of the museum of the great Tatar composer Nazib Gayazovich Zhiganov within the walls of the gymnasium with the Russian ethnocultural component always causes genuine surprise for everyone who came to this museum.

The museum arose with the active participation of the widow of the composer N.I. Zhiganova at the initiative of teachers of the gymnasium. The greatest contribution to the opening of the museum was made by E.V. Dugin. The friendship of these two women made the new school museum a worthy monument to the great musician.

In addition, within the walls of the gymnasium and in close cooperation with it, there is a children's music school No. 23, in which Shamil Gilmutdinovich, professor of the Kazan Conservatoire, one of the country's leading teachers, a high-class musician, a person who knew Zhiganov well, worked for several years after retirement. . Musical albums, booklets, programs, photographs were transferred from his personal archive as a gift to the school museum - everything connected with the name of Zhiganov.

With the active participation of schoolchildren, a museum exposition was created, work began on studying the composer's heritage, writing research papers, and drawing up excursion routes. Here they study music and its creators. Here they write essays, paint pictures, create films. Students successfully perform their work at competitions and conferences, which allows them to show not only knowledge and skills, but also to demonstrate the formation of such qualities as responsibility, tolerance, citizenship. 
A great influence on the development of the school museum and its vigorous activity belongs to the employees of the city museum-apartment of N. Zhiganova - Yakovleva L. A., Yegorova A. G.

Thematic lectures, days of music, days of memory, days of creativity, meetings with musicians, competitions of essays and projects - this is the scale for students' social activity.

In the school museums, the necessary documentation is created by the students, the existing fixed and auxiliary funds are recorded, the basics of museum professions are mastered.

Museums of the gymnasium for schoolchildren are a living memory and sociocultural values, this is an opportunity to touch the traditions and take an active part in their assimilation, preservation and transmission to future generations. This is history and creativity, this is socialization and career guidance, this is patriotism and civic self-identification.

By teaching, educating and developing, the school museum contributes to the development of a mature personality, the formation of civic activism and citizenship.

\section{References}

1. State program "Patriotic education of citizens of the Russian Federation for 2016-2020" [Electronic resource] - URL: http: //static.government.ru/media/ files/8qqYUwwzHUxzVkH1jsKAErrx2dE4q0ws.pdf - (Date of access: 12.03.2019)

2. Dyumina I.A. Patriotic education of students through the school museum // Man and education. 2012. No. 4 (33). S. 49-52.

3. Social studies. Grade 11: Textbook for general education. institutions: profile. level / L.N. Bogolyubov et al. - M.: Education, 2010. - p. 312.

4. Pedagogical dictionary. - M.: Academy. G. M. Kojaspirova, A. Yu. Kojaspirov. 2005.

5. Federal State Educational Standard for Basic General Education [Electronic resource] - URL: http://window.edu.ru/resource/768/72768/files/FGOS_OO.pdf - (Date of access: 12.03.2019). 
International Scientific and Practical Conference

PEDAGOGY AND MODERN EDUCATION

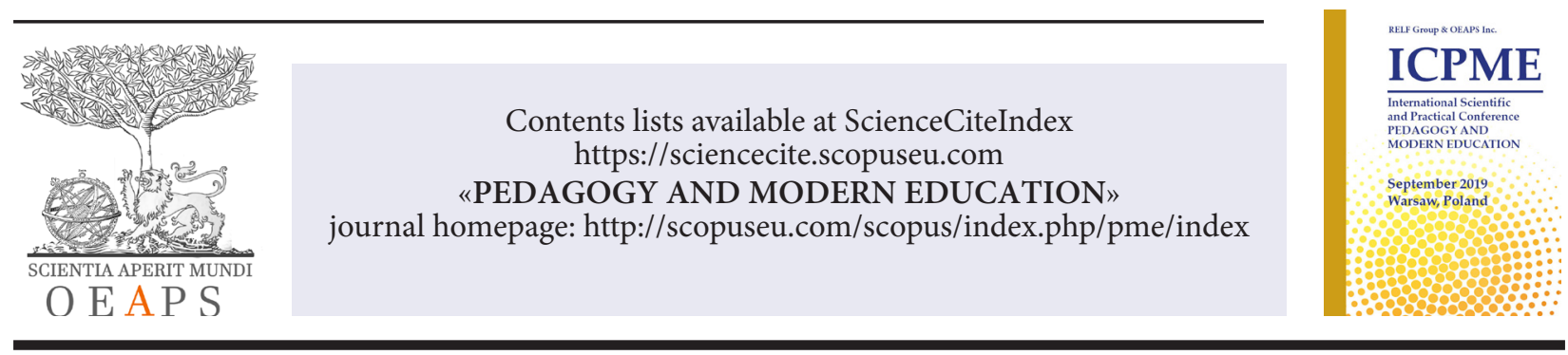

УДК 37.013

Патриотизм: осмысление исторических традиций воспитания

Синцова Людмила Константиновна

доктор философских наук, профессор

Алтайский государственный педагогический университет

Россия, г.Барнаул

Lud-Sintsova@yandex.ru

Patriotism: a reflection on the historical traditions of education

Sintsova Ludmila Konstantinovna

doctor of philosophy, professor

Altai State Pedagogical University

Russia, Barnaul

Аннотация: Статья посвящена актуальной для современного информационного общества проблеме патриотизма и патриотического воспитания, поскольку в глобализирующемся мире человек утрачивает свои исторические корни, свою национальную культуру. В статье рассматриваются традиции и новации патриотического воспитания в истории российского общества.

Abstract: the Article is devoted to the actual problem of patriotism and Patriotic education for the modern information society, because in the globalizing world people lose their historical roots, their national culture. The article discusses the traditions and innovations of Patriotic education in the history of Russian society.

Ключевые слова: патриотизм, воспитание, глобализация, патриотическое воспитание, русская философия, патриотические идеалы.

Key words: patriotism, education, globalization, patriotic education, Russian philosophy, hatriotic ideals.

(C) 2019 The Author. Published by OEAPS Inc. This is an open access article under the CC BY-NC-ND license (http://creativecommons.org/licenses/by-nc-nd/4.0/) 
Проблема патриотизма, осмысление его формирования и воспитания в новых исторических условиях развития современного российского общества актуальна как никогда. Определяющей тенденцией развития современного мира является глобализация, которая проявляет себя в объединении экономических и финансовых рынков, рынков образовательных услуг, формировании системы надгосударственных институтов, унификации культурного бытия народов, повседневной организации социума и т.д. Глобальный мир сегодня призван ориентироваться на интересы всего человечества. Однако в мире продолжает литься кровь, продолжаются войны, нарастает угроза террористических актов. И, несмотря на все политические лозунги, заверения и призывы политических лидеров следовать общечеловеческим ценностям, сегодня мы видим обостренную приверженность многих народов своим национальным интересам, верность своей исторической памяти, патриотический настрой. Процессы глобализации, вхождение России в глобальное экономическое, политическое, социальное пространство делают вопросы патриотического воспитания особенно актуальными. И как совершенно справедливо отмечает Г.А.Тихомиров, наша задача - не раствориться в космополитических настроениях, а патриотическими установками нацелить каждого человека, особенно молодое поколение, на служение Отечеству, активное деятельностное творчество во имя Родины. Стремления сохранить территориальную целостность страны, возродить ее былое могущество и авторитет как великой мировой державы нуждаются в опоре на ясно сформулированные патриотические идеалы [7, с.3].

Традиционно патриотизм определяется как любовь к родине, к своему отечеству, к своему народу. Патриотизм в «Толковом словаре русского языка» С.И.Ожегова и Н.Ю.Шведовой определяется как преданность и любовь к своему отечеству, к своему народу [2, с.496]. В ряде изданий при определении патриотизма авторы выделяют различные сущностные, базовые основания данного социального феномена: «любовь к родине, чувство ответственности за ее судьбу, готовность и способность служить ее интересам и способствовать ее успехам в сфере внутренней жизни и на международной арене» [3, с.125]; «нравственный и политический принцип, социальное чувство, содержанием которого является любовь к отечеству, преданность ему, гордость за его прошлое и настоящее, стремление защищать интересы родины» $[8$, с.335]; «социально-политический и нравственный принцип, выражающий чувство любви к родине, заботу о ее интересах и готовность к ее защите от врагов. Патриотизм проявляется в чувстве гордости за достижения родной страны, в горечи за ее неудачи и беды, в уважении к историческому прошлому своего народа, и бережном отношении к народной памяти, национально-культурным традициям [5]; «чувство любви к родине, идея, сознание гражданской ответственности за судьбы отечества, выражающиеся в стремлении служить ради своего народа, защиты его интересов» [6, с.31].

Анализ справочной литературы позволяет выделить в определении патриотизма различные базовые составляющие: чувство, деятельность, нравственный принцип, служение, сознание, идея, ценность и др. Подобное разнообразие подходов к определению сущности 
понятия «патриотизм» обусловлено многогранностью самого феномена, его нравственной, исторической и идеологической «чувствительностью».

Фундаментальным основанием для понимания природы и сущности патриотизма является определение его как исторического феномена. Многие исследователи обращают внимание на историческую составляющую патриотизма, его историческую наполненность, отмечая, что патриотизм - явление социально-историческое и в разные эпохи оно имеет разное социальное и классовое содержание. В.И.Лутовинов отмечает, что содержание и направленность патриотизма определяются, прежде всего, духовным и нравственным климатом общества, его историческими корнями, питающими общественную жизнь поколений [1].

Проблеме исторического развития феномена патриотизма уделяли значительное внимание многие видные представители русской философии (В.С.Соловьев, И.А.Ильин, В.В.Розанов, Н.А.Бердяев и мн. др.). Так, Вл.Соловьев, рассматривая проблему патриотизма, выделяет исторические тенденции его зарождения и развития. Он отмечает, что патриотизм - явление историческое. Исходный или «первичный патриотизм», как его называет Вл. Соловьев, держался «на кровной связи между членами отдельных небольших групп, чувство общественной солидарности совпадало с чувством семейным. Такой первичный патриотизм рода или племени совместен и с кочевым бытом. При переходе племен к оседлому земледельческому быту патриотизм получает свое специфическое значение, становясь любовью к родной земле» [9, с.37]. Далее Вл.Соловьев отмечает, что с развитием городов «развивается новый элемент патриотизма - привязанность к своей культурной среде или к родной гражданственности» [9, с. 37].

Следующий исторический этап формирования патриотизма, по мнению Вл. Соловьева, связан с появлением патриотизма в национальном виде. «В чисто национальном виде патриотическое чувство ярко проявилось в начале XV в. во Франции, в лице Иоанны д’Арк. Столетняя война французов с англичанами не имела принципиального характера в других отношениях: в религиозном - обе стороны принадлежали к одной и той же церкви, в политическом - к одному и тому же феодально-монархическому строю; основы быта общественного были одни и те же; война представлялась сначала лишь династической борьбой Валуа и Плантагенетов за престол Франции. Но постоянные встречи с чужим народным характером мало-помалу пробуждали у французов ревнивое чувство своей народности и вызвали, наконец, откровение национальной идеи. Иоанна д’Арк впервые дала простую и ясную формулу чисто национальному патриотизму: быть независимыми от чужеземцев на своей земле и иметь среди себя своего собственного верховного главу» [9, c.37].

Исторические типы патриотизма в значительной степени определяли содержание и формы воспитательной работы. Как показывает история, интерес к патриотическим идеалам, их воспитанию и формированию появляется не столько в дни празднеств, сколько в наиболее 
трудное для народа и его страны время, в периоды войн, нашествий, социальных конфликтов, кризисов и т.д.

На протяжении долгого времени в Советском Союзе существовала достаточно эффективная система патриотического воспитания, которая охватывала все население страны. Речь идет о системе образования, СМИ, литературе, живописи, кинематографе, которые в своем единстве были призваны сформировать чувство ответственности за судьбу своего Отечества, сопричастность истории своей страны. В данном направлении активно работали общественные организации. В стране реализовывалась моноцентрическая модель социального воспитания, цели которого определялись и диктовались государством.

В период перестройки сложилась либеральная (децентристская) модель социального воспитания, отличительной чертой которой является невмешательство государства в сферу воспитания. Это невмешательство способствовало активизации деятельности различных учреждений и организаций, социальных сообществ, которые влияли на формирование и воспитание подрастающих поколений, внедряя в молодежное сознание групповые и корпоративные ценности и идеалы. А.И. Субетто подчеркивал, что воспитание молодежи становится в условиях современной империалистической глобализации предметом ожесточенной войны, главная цель которой - подмена ценностей. Главной в новой системе ценностей является ценность богатства, денег, капитала, наживы, ради которой все «традиционные ценности» кладутся на заклание [6, с.32]. Система традиционных ценностей российского общества расшатывалась. В то время не было никаких моральных, гражданских, идеологических ограничений. Но больше всего «досталось» советскому патриотизму. Модным в период развала СССР стало высказывание английского поэта, критика и историка литературы Сэмюэля Джонсона: «Патриотизм - это последнее прибежище негодяев». Была поставлена под сомненье «целесообразность» тех жертв, которые страна понесла во имя победы в годы Великой Отечественной войны и в годы восстановления разрушенного хозяйства. Видимо, полное отрицание и забвение патриотизма как социально-исторического явления объясняет тот факт, что во многих справочных изданиях рубежа XX-XXI вв. определение патриотизма просто отсутствует.

Важным для понимания перемен в области патриотического воспитания является изменение взаимодействия образования и воспитания. Исторически сложившаяся в России неотделимость образования от воспитания была разрушена. Образовательные учреждения в какой-то момент ослабили свою воспитательную функцию, которая предполагала ориентацию на гуманистические ценности, на идеи патриотического воспитания, на признание самоценности культуры, образованности. Образовательные учреждения начали ориентироваться только на обучение. Разрыв между образованием и воспитанием в настоящее время нарастает за счет сокращения преподавания предметов имеющих значительный воспитательный потенциал, за счет вымывания гуманистической составляющей этих предметов. В последние годы в высших учебных заведениях наблюдается тенденция к 
сокращению учебных часов, отводимых на изучение дисциплин социогуманитарного цикла: философии, социологии, отечественной истории и др.

Однако, следует отметить, что в настоящее время помимо исторически сложившихся форм патриотического воспитания появляется новое для нашей страны направление, которое можно назвать семейной или устной историей. Получила широкую народную поддержку такая форма патриотического движения как Бессмертный полк, который объединил и поставил в строй каждого гражданина России, потому что нет в нашей стране семьи, в которой бы никто не воевал в годы Великой Отечественной войны. Стена памяти, где выставляют фотографии принимавших участие в войне родных и близких. Школьные сочинения (устная история), посвященные жизнеописанию своих родных, которые принимали участие в войне или работали в тылу. Все эти формы патриотического воспитания обращены к каждому человеку, они личностно направлены, делают каждого сопричастным великой победе, делают каждого победителем. Это как раз то, о чем писал Вл.Соловьев, что чувство общественной солидарности совпадает с чувством семейным.

Не только личностно ориентированные формы патриотического воспитания имеют место в настоящее время. Следует отметить, что Министерство образования и науки РФ раз в пять лет принимает программы «Патриотического воспитания граждан Российской Федерации», где отмечается, что условия современного мира и перемены в различных сферах российского общества требуют разработки новых форм патриотического воспитания. Новые формы патриотического воспитания, по мнению разработчиков программы, должны опираться «не на «казенный» патриотизм и изоляцию от внешнего воздействия», а на традиционные религии, общественные инициативы, деятельность военно-патриотических движений, спортивных обществ и исторических и краеведческих клубов, а также на семью. Авторы программы выделяют несколько вызовов времени перед современной Россией, которыенашли отражение в новой программе. В числе таких вызовов называется «деградация базисных ценностей», которая, как отмечают авторы, произошла из-за потери преемственности поколений, падения общего культурного уровня, а также «насаждения через СМИ, кино, литературу, интернет информации, искажающей традиционные для России исторические и духовно-нравственные ценности». Все это, несомненно, актуализирует патриотическое воспитание, поиски его новых форм. Историческая эпоха определяет содержание и формы патриотического воспитания, его исторические модели. 


\section{Список литературы}

1. Лутовинов В.И. Российский патриотизм: история и современность. http://o-patriotizme. narod.ru/Lutovinov2 rospatriotizm.htm

2. Ожегов С.И., Шведова Н.Ю. Толковый словарь русского языка. - Москва : Азь, 1996. $928 \mathrm{c}$.

3. Политическая энциклопедия. В 2т. Т.2. - М.: Мысль, 1999. - 701с.

4. Российская педагогическая энциклопедия : в 2 т. Т. 2. - М. : Большая Российская энциклопедия, 1999. Российская педагогическая энциклопедия : в 2 т. Т. 2. - М. : Большая Российская энциклопедия, 1999. Российская педагогическая энциклопедия : в 2 т. Т. 2. - М. : Большая Российская энциклопедия, 1999. - 672с.

5. Советская историческая энциклопедия : в 16т. Т. 10. - М. : Советская энциклопедия, 1967. Советская историческая энциклопедия : в 16т. Т. 10. - 534c.

6. Субетто А.И. Воспитание молодежи России в условиях современной глобализации // Актуальные проблемы социальной работы с молодежью в современной России: материалы Всерос. Науч.-практ. Конф. Санкт-Петербург, 21 окт. 2003 г. - СПб., 2003. С. 30-33.

7. Тихомиров Г.А. Социально-философское исследование феномена патриотизма. Автореферат канд.дис. канд. Филос.наук. Чебоксары, 2008. - 21с.

8. Философский словарь / Под ред. И.Т. Фролова. - М.: Политиздат, 1991. - 720с.

9. Энциклопедический словарь. Т.45. Раритетное воспроизведение издание Ф.А.Брокгауза - И.А.Эфрона. 1890г. «ТЕРРА» - «ТЕRRА»1992. - 474c.

\section{The text of the article in English}

The problem of patriotism, understanding of its formation and upbringing in the new historical conditions of development of modern Russian society is more relevant than ever. The determining trend in the development of the modern world is globalization, which manifests itself in the unification of economic and financial markets, markets for educational services, the formation of a system of supranational institutions, the unification of the cultural life of peoples, the daily organization of society, etc. Global peace today is designed to focus on the interests of all mankind. However, blood continues to pour in the world, wars continue, and the threat of terrorist acts is growing. And, despite all the political slogans, assurances and calls of political leaders to follow universal values, today we see the keen commitment of many peoples to their national interests, loyalty to their historical memory, and patriotic attitude. The processes of globalization, Russia's entry into the global economic, political, social space make issues of patriotic education particularly relevant. And as G.A. Tikhomirov quite rightly notes, our task is not to dissolve in cosmopolitan moods, but to aim every person, especially the younger generation, in serving the Fatherland, active and creative work in the name of the Motherland, with patriotic attitudes. The desire to preserve the territorial integrity of the country, to revive its former power and authority as a great world power, needs support on clearly formulated patriotic ideals [7, p.3]. 
Traditionally, patriotism is defined as love for the motherland, for one's homeland, for one's people. Patriotism in the "Explanatory Dictionary of the Russian Language" by S. I. Ozhegov and N. Yu. Shvedova is defined as devotion and love for one's homeland, one's people [2, p. 496]. In a number of publications, when defining patriotism, the authors identify various essential, basic foundations of this social phenomenon: "love of the homeland, a sense of responsibility for its fate, willingness and ability to serve its interests and contribute to its success in the sphere of domestic life and in the international arena" [3, p.125]; "A moral and political principle, a social feeling, the content of which is love for the fatherland, loyalty to him, pride in his past and present, the desire to protect the interests of the homeland" [8, p.335]; "A socio-political and moral principle that expresses a feeling of love for the motherland, concern for its interests and a willingness to protect it from enemies. Patriotism is manifested in a sense of pride in the achievements of the native country, in bitterness for its failures and troubles, in respect for the historical past of its people, and careful attitude to the people's memory, national and cultural traditions [5]; "A feeling of love for the homeland, an idea, a sense of civil responsibility for the fate of the fatherland, expressed in the desire to serve for the sake of their people, to protect their interests" [6, p.31].

An analysis of the reference literature allows us to identify various basic components in the definition of patriotism: feeling, activity, moral principle, service, consciousness, idea, value, etc. A similar variety of approaches to determining the essence of the concept of "patriotism" is due to the versatility of the phenomenon itself, its moral, historical and ideological "Sensitivity."

The fundamental basis for understanding the nature and essence of patriotism is its definition as a historical phenomenon. Many researchers pay attention to the historical component of patriotism, its historical fullness, noting that patriotism is a socio-historical phenomenon and in different eras it has different social and class contents. V.I. Lutovinov notes that the content and orientation of patriotism are determined, first of all, by the spiritual and moral climate of society, its historical roots that nourish the social life of generations [1].

The problem of the historical development of the phenomenon of patriotism was given considerable attention by many prominent representatives of Russian philosophy (V.S. Soloviev, I.A. Ilyin, V.V. Rozanov, N.A. Berdyaev, and many others). So, V. Soloviev, considering the problem of patriotism, identifies the historical trends of its origin and development. He notes that patriotism is a historical phenomenon. Original or "primary patriotism", as Vl. Solovyov, held on "blood communication between members of individual small groups, a sense of social solidarity coincided with a sense of family. Such primary patriotism of a clan or tribe is compatible with nomadic life. With the transition of tribes to a settled agricultural life, patriotism gets its specific meaning, becoming love for their native land" $[9$, p. 37]. Further, V. Soloviev notes that with the development of cities "a new element of patriotism is developing - attachment to one's cultural environment or to one's native citizenship" [9, p. 37]. 
The next historical stage in the formation of patriotism, according to V1. Solovyov, is associated with the emergence of patriotism in a national form. "In a purely national form, a patriotic feeling manifested itself vividly at the beginning of the 15th century. in France, represented by Joanna d'Arc. The centennial war between the French and the British did not have a fundamental character in other respects: in the religious, both sides belonged to the same church, in the political, to the same feudal-monarchist system; the basics of social life were the same; the war was at first only a dynastic struggle of Valois and Plantagenets for the throne of France. But constant meetings with a foreign national character, little by little, aroused among the French a jealous sense of their nationality and, finally, aroused the revelation of the national idea. For the first time, John d'Arc gave a simple and clear formula to purely national patriotism: to be independent of strangers in their own land and to have among themselves their own supreme head "[9, p. 37].

The historical types of patriotism largely determined the content and forms of educational work. As history shows, interest in patriotic ideals, their upbringing and formation appears not so much in the days of festivities as in the most difficult time for the people and their country, during periods of wars, invasions, social conflicts, crises, etc.

For a long time in the Soviet Union there was a fairly effective system of patriotic education, which covered the entire population of the country. We are talking about the education system, the media, literature, painting, cinema, which in their unity were called upon to form a sense of responsibility for the fate of their Fatherland, and the involvement of the history of their country. Public organizations actively worked in this direction. A monocentric model of social education was implemented in the country, the goals of which were determined and dictated by the state.

During the perestroika period, a liberal (decentralist) model of social upbringing developed, the hallmark of which is the state's non-interference in the sphere of upbringing. This non-interference contributed to the revitalization of various institutions and organizations, social communities, which influenced the formation and upbringing of younger generations, introducing group and corporate values and ideals into youth consciousness. A.I. Subetto emphasized that the upbringing of youth is becoming the subject of a fierce war in modern imperialist globalization, the main purpose of which is the substitution of values. Central to the new system of values is the value of wealth, money, capital, profit, for the sake of which all "traditional values" are put to the slaughter [6, p.32]. The system of traditional values of Russian society was shaken. At that time there were no moral, civil, ideological restrictions. But most of all "got" Soviet patriotism. Thefashionable during the collapse of the USSR became statement of the English poet, critic and literary historian Samuel Johnson: "Patriotism is the last refuge of villains." The "expediency" of those victims that the country suffered in the name of victory during the Great Patriotic War and during the years of restoration of the destroyed economy was called into question. Apparently, the complete denial and oblivion of patriotism as a socio-historical phenomenon explains the fact that in many reference publications of the turn of the XX-XXI centuries. the definition of patriotism is simply absent. 
Important for understanding the changes in the field of patriotic education is the change in the interaction of education and upbringing. The historically formed inseparability of education from upbringing was destroyed. Educational institutions at some point weakened their educational function, which included an orientation toward humanistic values, the ideas of patriotic education, and the recognition of the inherent value of culture and education. Educational institutions began to focus only on training. The gap between education and upbringing is currently widening due to a reduction in the teaching of subjects with significant educational potential, due to the washing out of the humanistic component of these subjects. In recent years, in higher education institutions there has been a tendency to reduce academic hours devoted to the study of the disciplines of the socio-humanitarian cycle: philosophy, sociology, domestic history, etc.

However, it should be noted that at present, in addition to the historically established forms of patriotic education, a new one is emerging for our country a direction that can be called family or oral history. Such a form of the patriotic movement as the Immortal Regiment, which united and put every Russian citizen into operation, received widespread popular support because there is no family in our country where no one fought during the years of World War II. Wall of memory, where photographs of relatives and friends who took part in the war are exposed. School essays (oral history) dedicated to the biography of their relatives who took part in the war or worked in the rear. All these forms of patriotic education are addressed to each person, they are personally oriented, make each person a great victory, make everyone a winner. This is exactly what Vladimir Solovyov wrote about, that a sense of social solidarity coincides with a family feeling.

Not only personality-oriented forms of patriotic education are taking place at the present time. It should be noted that the Ministry of Education and Science of the Russian Federation adoptsevery five years the Patriotic Education of Citizens of the Russian Federation program, where it is noted that the conditions of the modern world and changes in various areas of Russian society require the development of new forms of patriotic education. According to the program developers, the new forms of patriotic education should be based not on "official" patriotism and isolation from external influences, but on traditional religions, social initiatives, the activities of militarypatriotic movements, sports societies and historical and local history clubs, as well as per family. The authors of the program highlight several challenges of the time in front of modern Russia, which are reflected in the new program. Among these challenges are called "degradation of basic values", which, as the authors note, occurred due to loss of continuity of generations, a drop in the general cultural level, as well as "planting through the media, cinema, literature, and Internet information that distort historical and traditional Russian spiritual and moral values. "All this, of course, actualizes patriotic education, the search for its new forms. The historical era determines the content and forms of patriotic education, its historical models. 


\section{References}

1. Lutovinov V.I. Russian patriotism: history and modernity.http://o-patriotizme.narod.ru/ Lutovinov2 rospatriotizm.htm

2. Ozhegov S.I., Shvedova N.Yu. Explanatory dictionary of the Russian language. - Moscow: Az, 1996 - 928s.

3. Political Encyclopedia. In 2t. T.2. - M.: Thought, 1999 .- 701s.

4. Russian pedagogical encyclopedia: in 2 volumes T. 2. - M.: Big Russian encyclopedia, 1999. Russian pedagogical encyclopedia: in 2 volumes T. 2. - M.: Big Russian encyclopedia, 1999. Russian pedagogical encyclopedia: in 2 T. T. 2. - M.: Big Russian Encyclopedia, 1999. - 672s.

5. Soviet historical encyclopedia: in 16t. T. 10. - M.: Soviet Encyclopedia, 1967. Soviet Historical Encyclopedia: in 16t. T. 10. - 534s.

6. Subetto A.I. Education of the youth of Russia in the conditions of modern globalization // Actual problems of social work with youth in modern Russia: All-Russian materials. Scientific Pract. Conf. St. Petersburg, October 212003 - St. Petersburg, 2003 .- S. 30-33.

7. Tikhomirov G.A. Socio-philosophical study of the phenomenon of patriotism. Abstract of Cand. Cand. Philos. Cheboksary, 2008 .- 21 p.

8. Philosophical Dictionary / Ed. I.T. Frolova. - M .: Politizdat, 1991 .- 720s.

9. Encyclopedic Dictionary. T.45. Rare reproduction edition F.A. Brockhaus - I.A. Efron. 1890 "TERRA" - "TERRA" 1992. - 474s. 
International Scientific and Practical Conference

PEDAGOGY AND MODERN EDUCATION

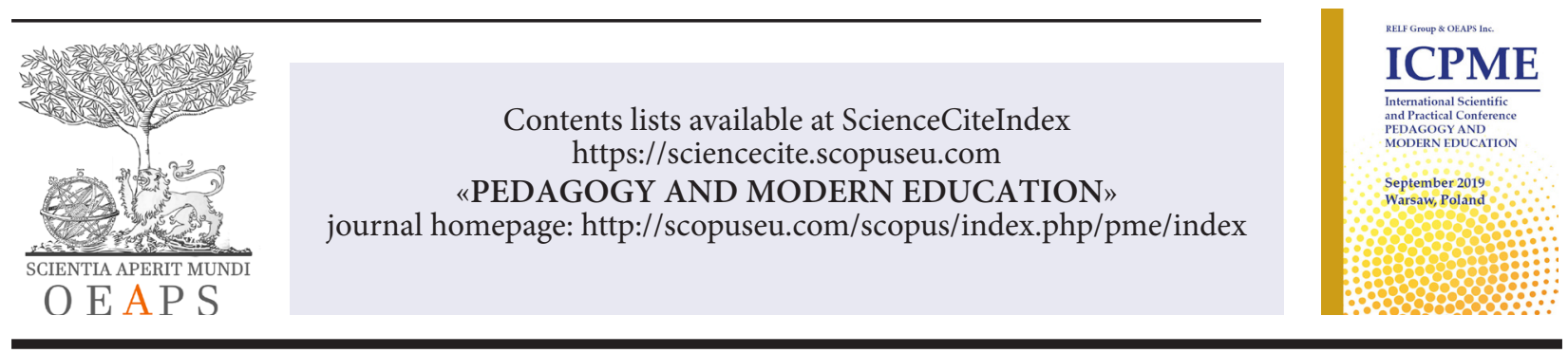

Model of 21st Century Physical Learning Environment (MoPLE21)

\author{
Cezary Szpytma \\ Rzeszow University of Technology \\ Rzeszów, Poland \\ sci@scopuseu.com \\ Magdalena Szpytma \\ Rzeszow University of Technology \\ Rzeszów, Poland
}

\begin{abstract}
The physical learning environment is often considered to be a secondary element of education. Therefore, this study examined the following research questions: What role does the physical learning environment play in the educational process? How can we adapt the physical learning environment to 21 st century education? The present study analyzed behavioral models and reviewed 21 st century educational frameworks. Based on the findings, an ideal school environment model, called the MoPLE21, is presented and can be viewed online as an appendix of this paper at https://mople21.org. Our results show that the physical environment is an important and often underestimated factor in education, and an appropriately designed school environment can play a significant role in the 21 st century teaching and learning process. Finally, the MoPLE2 1 is discussed as an interdisciplinary tool for educational theorists and professionals for design, assessment, and everyday use in learning environments.
\end{abstract}

Keywords: Interdisciplinary Approach, 21st Century Education, Creative and Cultural Education, Teaching and Learning Process, School Design

\title{
1. Introduction
}

The physical learning environment is most often considered to be of secondary importance in the education process. Nonetheless, increasing numbers of educators are becoming aware that the physical learning environment "defines the circumstances in which children enter the public arena," and "it is through the school architecture that ideas about collective life are communicated

(c) 2019 The Author. Published by OEAPS Inc. This is an open access article under the CC BY-NC-ND license (http://creativecommons.org/licenses/by-nc-nd/4.0/) 
to children" (Van Den Driessche, 2007, p. 82). Researchers have remarked that a properly designed school building "helps teachers prepare young people for the demands of modern life, for flexibility, co-operation, thus making them competent navigators of an educational system that focuses on knowledge sharing and leaving room [sic] for inspiration" (Klawonn, 2010, p. 37).

Therefore, school buildings should not be viewed merely as the location of the education process or simply a safe place for pupils and teachers to learn and teach. Rather, the physical learning environment should represent the materialization of a society's ideas and values while creating optimal spaces for the teaching and learning process to occur (Burke \& Grosvenor, 2008, p. 8). Thus, rather than being of secondary importance, school buildings are an essential aspect of education.

Hence, the idea underlying the present study was to improve the use of school architecture to support 21 st century education. This study examined the following research questions:

A. What role does the physical learning environment play in the educational process?

B. How can we adapt the physical learning environment to 21 st century education?

This article reviews the literature on the relationship between architecture and education. Based on this review, the authors developed the theoretical Model of 21st Century Physical Learning Environment (MoPLE21), which is concerned with identifying optimal educational spaces. In sum, the MoPLE21 synthesizes education and architecture through psychological concepts. In the following sections the key issues in these three disciplines are introduced and the educational context for the MoPLE21 is presented.

\section{Literature review}

\subsection{Educational background: toward change}

Movements for reforming the ossified education system began to appear at the beginning of the 20th century known as "New Education" in Europe and "Progressive Education" in the USA. The child-centered approach of prominent educators of that movement (Montessori, Steiner, Dewey) emphasized criteria such as: imagination, aesthetics, critical thinking, experiential learning, collaboration, education for social responsibility, creativity, and personalized learning (Gidley, 2016, pp. 134-135). In the 1970s and 1980s "alternative education" emerged as a new wave of criticism of traditional mass education in Western world and part of Latin America (Gidley, 2016, p. 136). The concepts of that time covered a wide spectrum of educational views: from critical education focused on political awareness and social justice (Freire, 1970) to anarchist abandonment of the public schooling system (Illich, 1975). Unfortunately, some of the proposed valuable changes conceived during these two eras have never been widely implemented. Today we face a "third evolutionary wave" in education (Gidley, 2016, p. 137), and the need for a paradigm shift is clear (Kennedy, Latham, \& Jacinto, 2016, p. 80). Kennedy et al. (2016) showed that the traditional 
model of education is widely criticized for its emphasis on academic knowledge, teacher-centered instruction, and its use of transmissive methods of knowledge transfer (Kennedy et al., 2016, pp. 79-82). Robinson (2010) pointed out that the "current system of education was designed, and conceived, and structured for a different age. It was conceived in the intellectual culture of the Enlightenment and in the economic circumstances of the Industrial Revolution," and it is no longer sufficient.

Many believe that the archaic education system cannot keep up with the current, rapidly changing era of "liquid modernity" (Bauman, 2013) and "digital natives" (Prensky, 2001). Recently published findings seem to confirm this opinion. A study by the Institute for the Future \& Dell Technologies indicated that an estimated 85 percent of jobs in 2030 have not been invented yet (2017). The authors of that study predicted "in-the-moment learning will become the modus operandi, and the ability to gain new knowledge will be valued higher than the knowledge people already have" (p. 14). For this reason, Zhao (2014) lamented that China has already suffered from a lack of innovative talents. He argued that even though Chinese students perform the highest on the standardized Programme for International Student Assessment (PISA), making them a target of global admiration, this situation has effectively prevented reform of the Chinese education system (Zhao, 2014).

Recently, much attention has been paid to educational changes and themes such as developing 21 st century skills and competencies. These requisite abilities include creativity, critical thinking, divergent thinking, originality, and individualism (Piirto, 2011; Zhao, 2014); "high-level skills, knowledge, attitudes, and characteristics of self-directed and collaborative learning" (Griffin, McGaw, \& Care, 2012, p. vi); and self-learning, networked learning, and lifelong learning (Davidson \& Goldberg, 2009, pp. 26-35). Such 21st century skills are essential in preparing young learners for the future.

Furthermore, many researchers believe that the learning environment plays a significant role in education (Cleveland \& Fisher, 2014; Davies et al., 2013, pp. 84, 88; Higgins, Hall, Wall, Woolner, \& McCaughey, 2005; Weinstein, 1979); at the same time however they emphasize the complexity of that relationship and the inconclusive evidence (Higgins et al., 2005; Woolner, Hall, Higgins, McCaughey, \& Wall, 2007). Moreover, most have interpreted the learning environment as a social (Partnership for 21st Century Learning [P21], 2017a, pp. 8-9), institutional (National Advisory Committee on Creative and Cultural Education [NACCCE], 1999, pp. 138, 144), cultural (Mishra \& Mehta, 2017, p. 15), or computer-based (Binkley et al., 2012, p. 32; Voogt \& Pareja Roblin, 2012, p. 14) environment rather than a physical setting. Other studies have confirmed that the physical learning environment has not been widely regarded as being at the interaction level in the teaching and learning process. Moore (1989, pp. 2-5) specified three levels of learner- environment interaction: learner-content, learner-instructor, and learner-learner, while Bruno and Munoz (2010, p. 367) specified four levels: learner-teacher, learner-artefacts, learner- learning situation, and learner-community/classroom. However, none of these researchers deny the existence of other levels of interaction. 


\subsection{Psychological background: toward understanding}

Lewin first wrote about the effects of the environment on human behavior. His famous equation $\mathrm{B}=\mathrm{f}(\mathrm{P}, \mathrm{E})$, meaning that behavior is a function of a person in his or her environment (Lewin, 1936, p. 12), has become standard. Lewin understood the physical environment primarily as a context or structure for the cultural and social environment (Lewin, 1936, $\mathrm{p}$.

20). Continuing Lewin's work, Barker developed Lewin's ideas further, shaping the foundations of environmental psychology. In his seminal work, Barker presented the concept of "behavior settings" (Barker, 1968): he provided quantitative evidence supporting the concept and the basic methodology for measuring the phenomenon. Barker's behavior setting theory was perceived from the beginning as an elegant explanation of the development of human personality, culture, and behavior as derivatives of both individual features and the influence of environment (Hall, 1969, p. 1186). Significantly, Barker was interested in the way that built environments affect human behaviors. He proved that the number of behavior settings does not depend on the size of a school. This was demonstrated through the more diverse roles and greater involvement of students in small high schools compared to large high schools (Barker \& Gump, 1964).

The next step in studying the impact of the physical environment on human behavior was in the field of visual perception (Gibson, 1977, pp. 67-82, 1979). Gibson stated that the mind perceives environmental stimuli directly, with no cognitive processing. His research resulted in affordance theory. According to Gibson, "affordances of the environment are what it offers the animal, what it provides or furnishes, either for good or ill" (Gibson, 1979, p. 127). Affordance theory became as influential as it was controversial and has been widely discussed. Some researchers criticized Gibson's theory for its incompleteness and promotion of direct perception, which cannot explain cognitions of higher-order abstractions (Bickhard \& Richie, 1983, p. 17, 64), or its lack of a representation layer (Bickhard \& Campbell, 1996, p. 114). The definition of "affordance" itself was considered too simplistic and unclear (Norman, 2013, pp. 13-14, 309). A clarified definition of affordance in relation to perceptual information was later proposed by Gaver, in which he distinguished perceptible, hidden, and false affordances (Gaver, 1991).

More recent studies similarly divide affordances into subjective and objective types (Tillas, Vosgerau, Seuchter, \& Caiani, 2017, p. 313), claim that affordances often invite or solicit action (Kaufer \& Chemero, 2015; Withagen, Araújo, \& de Poel, 2017), and explore the role of individual differences and emotions in response to affordances (Withagen, 2018).

The influence of the physical environment on human behavior is still studied in different contexts. Interestingly, confirmations have been found in the field of medicine. Noteworthy studies are those that have related obesity with one's relationship to their environment (Garfinkel-Castro, Kim, Hamidi, \& Ewing, 2016). It has been argued that "obesity is linked to the built environment as a consequence of human behavior - in this case physical activity" (Garfinkel-Castro et al., 2016, 
p. 276). Other studies have reported similar findings concerning the correlation between built environments and mental health (Evans, 2003; Halpern, 2013). For example, Golembiewski (2016) argued that specific environments can trigger mental illnesses and foster mental oversensitivity.

\subsection{Architectural background: toward interaction}

The most influential theorist of modern architecture - Le Corbusier - believed that architecture had the potential to solve overpopulation, commuting, and infrastructure problems in interwar cities. However, it can also form "modern man" by meeting new universal needs and the "modern society" with new patterns of social life (Graham, 2016, pp. 77-114; von Moos, 2009, pp. 144, 147, 265, 316). Le Corbusier presented his concepts in his utopian project Plan Voisin (1925). It included the demolition of several of Paris's historical buildings and the construction of 60-story high-rise buildings that would house 3 million residents in a vertically constructed city. Le Corbusier's intention with this revolutionary urban design was to create a completely new way of inhabiting and using the city (Le Corbusier, 1987, p. 167). Le Corbusier saw human behavior as dependent on the built environment in which they live, stating that the architect "determines the various movements of our heart and of our understanding" (Le Corbusier, 1986, p. 1). However, his utopian ideas have not been widely accepted and can be labeled as "architectural determinism", according to the term coined in 1966 by sociologist Maurice Broady (Broady, 1966). With this term, Broady criticized the authoritarian belief that the built environment is the main or even sole factor in shaping social behaviors. Nevertheless, Broady admitted that architecture can limit and channel behavior in a predictable manner.

Today it would be naive to think that the physical environment is the only determinant of human behavior. Over time, views about the influence of the physical environment on human behaviors evolved toward the more liberal "architectural possibilism" (i.e., behavior can be limited but not restricted by the physical environment) and "architectural probabilism" (i.e., behavior can be predicted with a certain probability by the physical environment) (Strange \& Banning, 2001).

A broader interdisciplinary understanding of architecture with a clearer approach to the social sciences began in the 1960s and 1970s. Urban planner Kevin Lynch stated that our visual perception of the urban environment plays a significant role in the everyday lives of individuals: for operating, moving, emotional security, and the intensity of experience (Lynch, 1960, pp. 4-5). Other prominent architectural theorists of that time argued in a similar tone that "architecture [...] is based on a number of human instincts, on discoveries and experiences common to all of us at a very early stage in our lives" (Rasmussen, 1962, p. 14).

Rasmussen's position was further developed by architect Jan Gehl, best known for his work in Copenhagen. In the 1960s, he began to reconfigure the capital of Denmark from a city planned around cars to a city planned around people. Gehl's ideas about architecture, which were aimed 
at satisfying human needs and focused on peoples' behaviors (Gehl, 1987, 2010), became highly influential among the next generation of architects. His successes drew architects' attention to the large roles that sociology and psychology play in architectural design. Those roles have been recently confirmed by post-occupancy evaluation research of laboratory buildings. Its results have shown that proper architectural design (taking into account psychological and sociological aspects) can facilitate interactions among researchers, enhance collaboration, and improve efficiency (Goldstein, 2006).

In the context of designing physical learning environments, the leading figure is undoubtedly Dutch architect Herman Hertzberger. With his numerous publications on school architecture (Hertzberger, 1991, 1999, 2008; Hertzberger \& de Swaan, 2009), he has shaped successive generations of architects in the spirit of humanism with a focus on school users, rather than on the school building itself. Hertzberger, in line with Gibson's theory, encouraged architects to design buildings that were open to interpretation, with many possible affordances to discover (Withagen, de Poel, Araújo, \& Pepping, 2012, p. 254). His key project of the Delft Montessori School (1960-1966) became an icon and one of the few examples of school buildings corresponding significantly with the implemented educational program.

\section{Materials and methods}

\subsection{Behavioral models}

Various behavioral models have been advanced by researchers (Bandura, 1978, 2001; Bowers, 1973; Lewin, 1936). Appendix A provides a brief review of key behavioral models with brief explanations of each. The evolution of behavioral models provided a basis for creating the MoPLE21 at a later stage in this study.

\section{2. $\quad$ Affordance distinction}

For the MoPLE21, Gibson's theory of affordance was adopted, as well as the concept of dividing affordance distinction into four regions developed by Gaver. The original distinction formulated by Gaver is shown in Table 1. 
International Scientific and Practical Conference

PEDAGOGY AND MODERN EDUCATION

Table 1. Affordance distinction in relation to perceptual information (based on Gaver, 1991)

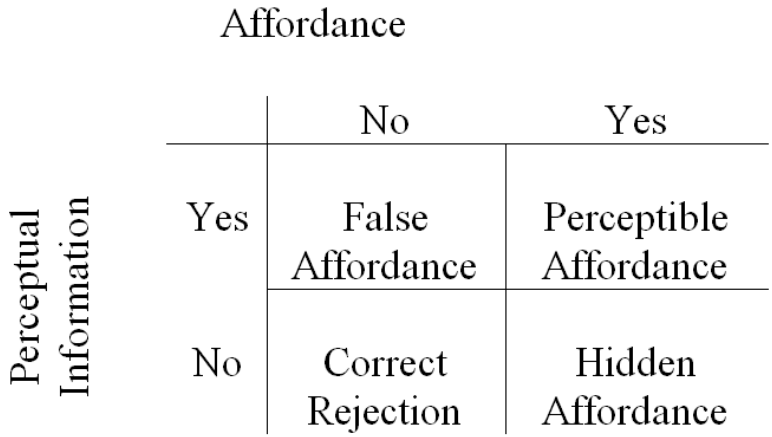

\section{3. $\quad$ Specifying 21st century competencies}

Since the late 1990s, new frameworks have emerged specifying new competencies and categories for 21 st century education. Interestingly, although there are differences in categories according to different frameworks, convergence is observed at the level of single competencies (Voogt \& Pareja Roblin, 2012, p. 315). The naming of categories is considered of secondary importance, as these are only the designators given by different authors. The specifying of individual 21st century competencies is much more important. Appendix B lists six significant frameworks (i.e., review articles, books, and collective reports) that were used for further analysis. Based on the listed frameworks 29 competencies were specified and grouped into three categories: foundational knowledge (to know), cultural education (to value), and creative education (to act).

\section{4. $\quad$ Elements of the physical learning environment}

The term "learning environment" less frequently refers to the physical learning environment or space than to the social, psychological, or conceptual environment (Cleveland \& Fisher, 2014, p. 1). In their comprehensive literature review, Cleveland and Fisher (2014) analyzed six methods of physical learning environment evaluation. They diagnosed the lack of pedagogical perspective as a gap in almost all presented approaches. Almost all methods are focused "on the physical features of the physical environment itself, rather than the alignment between spaces and desired educational practices, activities, and behaviors" (Cleveland \& Fisher, 2014, p. 25). The only analyzed method that includes a pedagogical perspective is that proposed by Sanoff (2001).

However, individual elements of the physical learning environment with clear educational approaches were listed and grouped by Walden (2009, pp. 169-187). Walden's criteria supplemented with those of Sanoff and pilot studies conducted by the authors of the present study in several European schools formed the basis for the development of the MoPLE21 in a later stage of this study. 


\subsection{Theory and calculation}

In all behavioral models mentioned in Appendix A, the $\mathrm{E}$ factor was interpreted mainly as the social environment (Kihlstrom, 2013, p. 793). Starting with Bandura's (1978) reciprocal determinism model, further research was aimed at creating a model referring to the physical learning environment, such as the development of the site plan and architecture of the school building. Appendix C lists the next stages of creating the MoPLE21 with visual representations.

\section{Results}

As the final result of this research, the MoPLE21 was developed on the basis of the theory formulated in the previous section, Theory and calculation. The MoPLE21 organizes the relationships between education and the physical learning environment using environmental psychology. The MoPLE21 is presented as an online appendix at https://mople21.org. Figures 1-3 present the basic elements of the website.

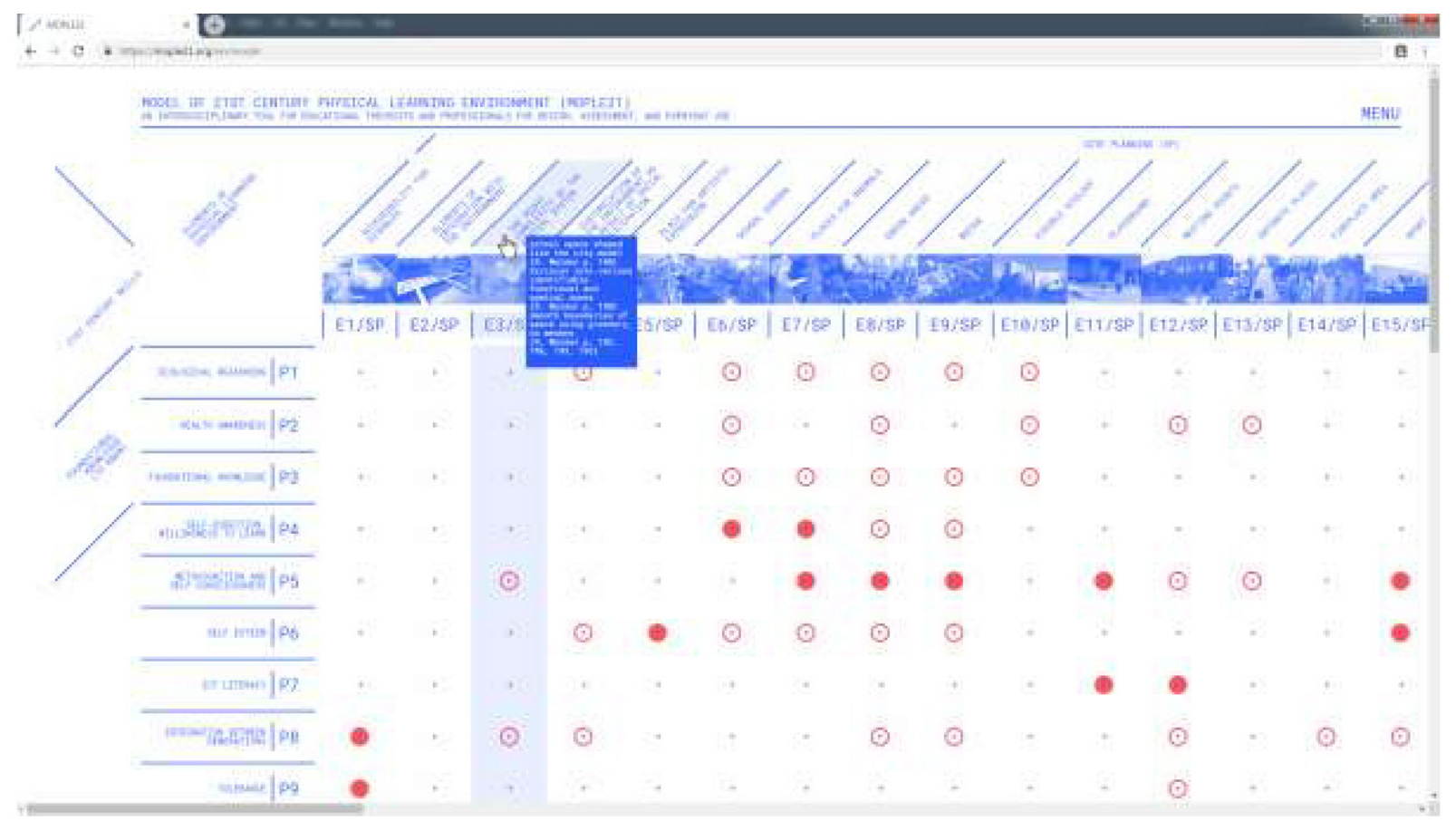

Figure 1. The basic view of the online presentation of the MoPLE21. After clicking on the highlighted column, you can expand it. (In this case, column E3/SP is highlighted.) After hovering over the names of the rows and columns, an extension of the name with references appears. 


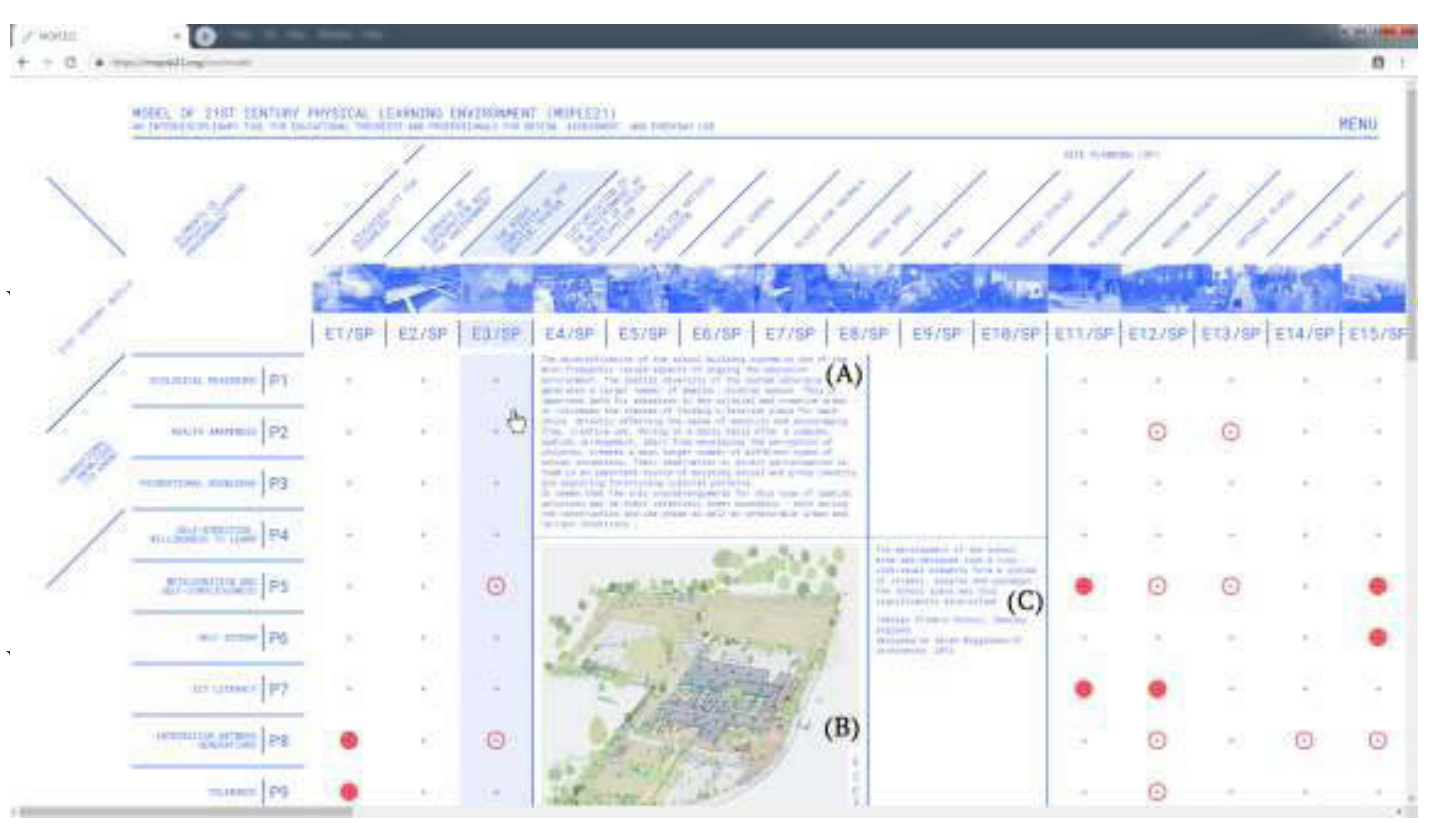

Figure 2. After clicking on the selected column, a scrollable table appears. The table contains a description of the selected element of the environment and its possible use in the teaching and learning process (A). Below the description there are several examples illustrating the selected element (B) with brief comments (C).

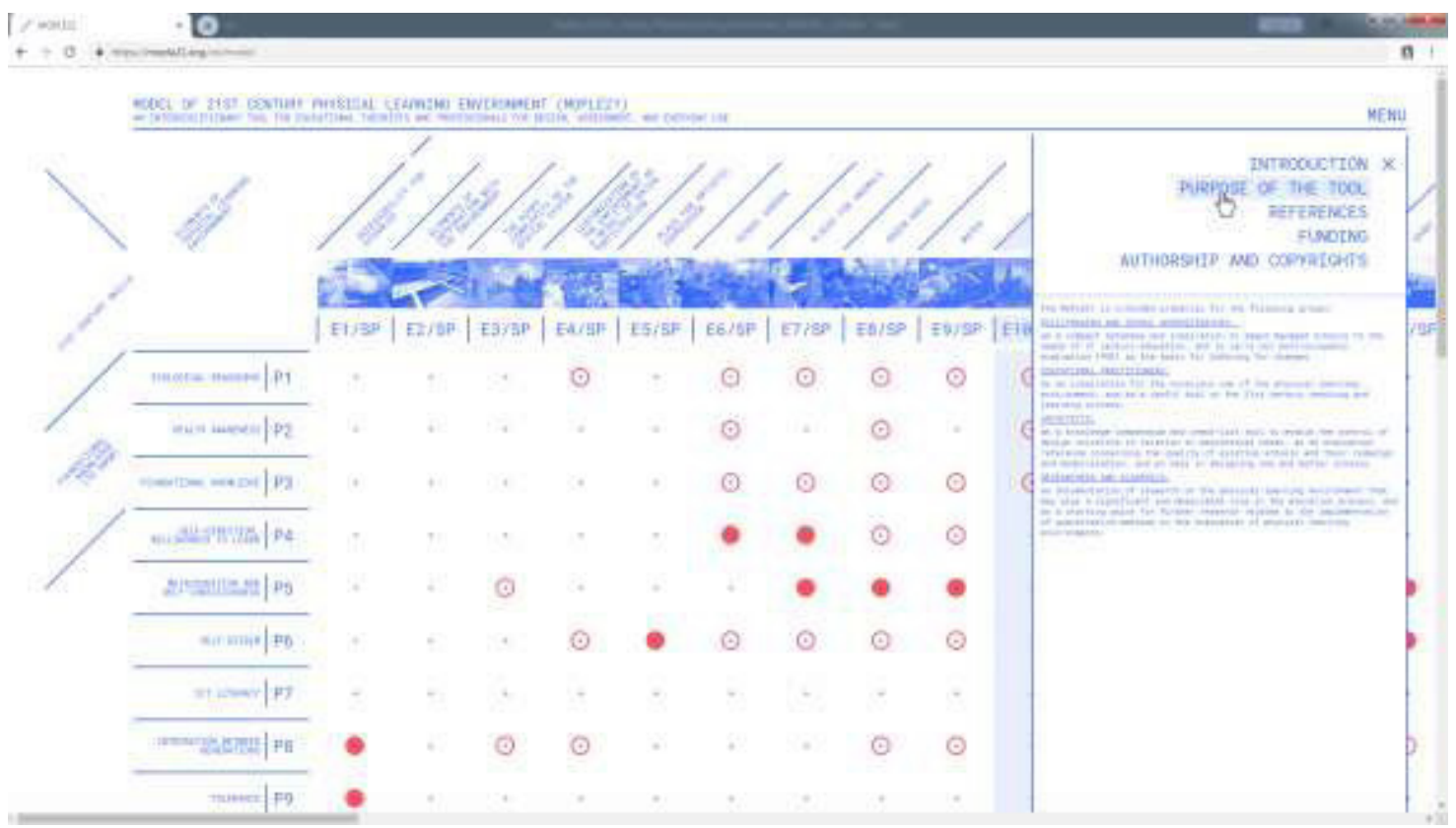

Figure 3. Clicking on "MENU" reveals a section containing a short explanation of the research addressed to a wide audience. This section can be closed by clicking $\mathrm{X}$. 


\section{Discussion and conclusions}

The results of the present study led to the development of the MoPLE21. With environmental psychology as a connector, the MoPLE21 combines education and architecture. It presents the physical learning environment of schools as a possible interaction level in education.

The present study has also shown robust correlations between education, architecture, and psychology. Thus, interdisciplinary approaches are essential for shaping the physical educational environment and its appropriate use in the education process. However, in practice, interdisciplinary approaches have been applied in a very limited manner. For example, there is a conspicuous lack of psychology knowledge concerning human behavior among architects. On the other hand, teachers most often view the physical learning environment very objectively. Furthermore, environmental psychology is still marginalized within the field of psychology (Heft, 2013). Therefore, this work can be read as an attempt to restore the position of environmental psychology, interdisciplinary approaches, and the incentive to use knowledge from three related disciplines to advance educational practices.

The research questions posed at the beginning of this paper were thus answered as follows:

A. The MoPLE21, with reference to behavioral models provided by environmental psychology, explains the influence of built environments on cognitive and personal factors. The MoPLE21 defines the role of the physical learning environment as a new interaction level in 21st century education and presents its potential as a tool in the teaching and learning process.

B. The MoPLE21 can be used as a simple tool for evaluating existing school environments or designing new ones, as it represents the ideal school environment. In cases of existing schools and schools still in the design process, it may be used for reference and comparison.

\subsection{Study implications}

At the theoretical level, the present study showed that the physical learning environment may be considered as the next interaction level in education. However, the MoPLE21 was also developed to serve both as a methodological and a practical tool. The systematization of 67 elements of the physical learning environment was designed for use by representatives of all educational sectors. It is intended primarily for the following groups:

A. Researchers of education and other related disciplines: as documentation of research on the physical learning environment that may play a significant and measurable role in the education process; as an exposition of interdisciplinary research and thus an extension of fields of study in education; as a starting point for further research related to the implementation of quantitative methods in the evaluation of physical learning environments; and as a demonstration of the practical implementation of environmental psychology and architecture in education. 
B. Policymakers and school administrators: as a compact database and inspiration to adapt managed schools to the needs of 21 century education, and to carry out post-occupancy evaluations (POE) as the basis for lobbying for changes.

C. Educational practitioners: as an inspiration for the conscious use of the physical learning environment, and as a useful tool in the 21 st century teaching and learning process.

D. Architects: as a knowledge compendium and check-list tool to enable the control of design solutions in relation to educational needs; as an evaluation reference concerning the quality of existing schools and their redesign and modernization; and as a resource in designing new and better schools.

\subsection{Future research}

The physical learning environment was not traditionally considered a level of interaction in the teaching and learning process. This article presents the theoretical concept of the physical learning environment as one of these interaction levels. However, further research is required. At this stage, the MoPLE21 represents a summary of the theoretical work, which requires some further empirical verification and development, and perhaps some corrections (see Study Limitations section). The MoPLE21 should be treated as a working version, which will be updated as the results of further research are obtained.

The MoPLE21 can also be used as a general sketch and starting point to exact original research studies on each of the 67 listed elements of the physical learning environment and its role in education. The first step would be a comparative analysis of the quality of the elements of selected schools with the MoPLE21, as well as an assessment of the impact of these environments on the teaching and learning process. Further adjustment of the elements and re-evaluation is required.

\subsection{Study limitations: the ontological dilemma in design disciplines}

The research is based on verified and widely accepted psychological concepts concerning the impact of the physical environment on human behavior and cognitive features. These concepts have been implemented in the theoretical MoPLE21. However, the MoPLE21 has a heuristic nature at the level of seeking and categorizing single behaviors. At this point, the research can be interpreted as revealing a well-known ontological dilemma in design disciplines.

Studies in the field of design disciplines are often maintained in the field of heuristic and qualitative research and criticized for being too subjective and intuitive. They are accused of having a lack of traditionally understood scientific proof, which is believed to be guaranteed in quantitative research. This is because many problems in the field of design cannot be tested in a laboratory context. On the other hand, conducting reliable experiments outside of the lab is often technically and economically impossible. For instance, "poor- quality housing appears to increase psychological distress, but methodological issues make it difficult to draw clear conclusions" (Evans, 2003, p. 536). This problem was also noticed by Dewey: 
As Dewey (1934) points out, the realist ontology of the natural sciences is no more useful for understanding design than it is for understanding human experience. The problem lies, according to Dewey, in the fact that the natural sciences are backward looking inasmuch as they seek to describe the way the world is, whereas the problem of design is to create an understanding of the way we might want the world to be. So instead of objective description it is necessary to place creative imagination and ways of seeing at the centre of our approach (Wright \& McCarthy, 2005, pp. 12-13).

Conducted research can be partially confirmed by observations of school functioning, the education process, and children's behavior. For example, creating and managing a school garden will allow children to develop practical skills in the field of cultivation, and with appropriate input from the teacher, a better understanding of healthy eating. Objectively, the MoPLE21 is based in that part on hypotheses. Although, from the heuristic point of view, single hypotheses often seem obvious, they may require direct confirmation and should thus be subject to further research.

Acknowledgements: This project was partially funded under grants DS.M.BP.17.001 and DS.BP.18.001.01.

\section{Declarations of Interest: none}

\section{References}

Bandura, A. (1978). The self system in reciprocal determinism. American Psychologist, 33(4), 344-358. http://doi.org/doi.org/10.1037/0003-066X.33.4.344

Bandura, A. (2001). Social cognitive theory: An agentic perspective. Annual Review of Psychology, 52(1), 1-26. http://doi.org/10.1146/annurev.psych.52.1.1

Barker, R. G. (1968). Ecological psychology: Concepts and methods for studying the environment of human behavior. Palo Alto, CA: Stanford University Press.

Barker, R. G., \& Gump, P. V. (1964). Big school, small school: High school size and student behavior. Stanford, CA: Stanford University Press.

Bauman, Z. (2013). Liquid modernity. Hoboken, NJ: Wiley.

Bickhard, M. H., \& Campbell, R. L. (1996). Topologies of learning and development. New Ideas in Psychology, 14(2), 111-156. http://doi.org/10.1016/0732-118X(96)00015-3

Bickhard, M. H., \& Richie, D. M. (1983). On the nature of representation: A case study of James Gibson's theory of perception. New York: Praeger. 
Binkley, M., Erstad, O., Herman, J., Raizen, S., Ripley, M., Miller-Ricci, M., \& Rumble, M. (2012). Defining twenty-first century skills. In P. Griffin, B. McGaw, \& E. Care (Eds.), Assessment and Teaching of 21st Century Skills (pp. 17-66). Dordrecht: Springer Netherlands.

Bowers, K. S. (1973). Situationism in psychology: An analysis and a critique. Psychological Review, 80(5), 307-336. http://doi.org/10.1037/h0035592

Broady, M. (1966). Social theory in architectural design. Arena, the Architectural Association Journal, 81(898), 149-154.

Bruno, S., \& Munoz, G. (2010). Education and interactivism: Levels of interaction influencing learning processes. New Ideas in Psychology, 28(3), 365-379. http://doi.org/10.1016/j. newideapsych.2009.09.011

Burke, C., \& Grosvenor, I. (2008). School. London: Reaktion Books.

Cleveland, B., \& Fisher, K. (2014). The evaluation of physical learning environments: A critical review of the literature. Learning Environments Research, 17(1), 1-28. http://doi.org/10.1007/ s10984-013-9149-3

Davidson, C. N., \& Goldberg, D. T. (2009). The future of learning in a digital age.

Cambridge, MA: MIT Press.

Davies, D., Jindal-Snape, D., Collier, C., Digby, R., Hay, P., \& Howe, A. (2013). Creative learning environments in education-A systematic literature review. Thinking Skills and Creativity. http:// doi.org/10.1016/j.tsc.2012.07.004

Dewey, J. (1934). Art as Experience. New York: Pedigree.

Evans, G. W. (2003). The built environment and mental health. Journal of Urban Health, 80(4), 536-555. http://doi.org/10.1093/jurban/jtg063

Freire, P. (1970). Pedagogy of the oppressed. New York: Herder and Herder.

Garfinkel-Castro, A., Kim, K., Hamidi, S., \& Ewing, R. (2016). The built environment and obesity. In R. S. Ahima (Ed.), Metabolic syndrome: A comprehensive textbook (pp. 275- 286). Cham, Switzerland: Springer International Publishing.

Gaver, W. (1991). Technology affordances. In P. S. Robertson, M. G. Olson, \& J. S. Olson (Eds.), Human factors in computing systems. New York: Addison-Wesley.

Gehl, J. (1987). Life between buildings: Using public space. New York: Van Nostrand Reinhold. 
Gehl, J. (2010). Cities for people. Washington, DC: Island Press.

Gibson, J. J. (1977). The theory of affordances. In R. Shaw \& J. Bransford (Eds.), Perceiving, acting, and knowing: Toward an ecological psychology (pp. 67-82). Hillsdale, NJ: Lawrence Erlbaum.

Gibson, J. J. (1979). The ecological approach to visual perception. Boston: Houghton Mifflin.

Gidley, J. M. (2016). Postformal in education: Beyond the formal factory model. In Postformal education: A philosophy for complex futures (pp. 133-156). Cham, Switzerland: Springer International Publishing.

Goldstein, R. N. (2006). Architectural design and the collaborative research environment. Cell, 127(2), 243-246. http://doi.org/10.1016/j.cell.2006.10.007

Golembiewski, J. A. (2016). The designed environment and how it affects brain morphology and mental health. HERD: Health Environments Research \& Design Journal, 9(2), 161-171. http://doi. org/10.1177/1937586715609562

Graham, W. (2016). Dream cities: Seven urban ideas that shape the world. New York: Harper Collins.

Griffin, P., McGaw, B., \& Care, E. (2012). Assessment and teaching of 21st century skills. Dordrecht: Springer.

Hall, E. T. (1969). Ecological psychology concepts and methods for studying the environment of human behavior by Roger G. Barker. American Anthropologist, 71, 1184-1186. http://doi. org/10.1525/aa.1969.71.6.02a00440

Halpern, D. (2013). Mental health and the built environment: More than bricks and mortar? New York: Routledge.

Heft, H. (2013). An ecological approach to psychology. Review of General Psychology, 17(2), 162-167. http://doi.org/10.1037/a0032928

Hertzberger, H. (1991). Lessons for students in architecture. Rotterdam: 010 Publishers. Hertzberger, H. (1999). Space and the architect. Lessons in architecture 2. Rotterdam: 010 Publishers.

Hertzberger, H. (2008). Space and Learning. Lessons in architecture 3. Rotterdam: 010 Publishers. Hertzberger, H., \& de Swaan, A. (2009). The schools of Herman Hertzberger. Alle scholen. Rotterdam: 010 Publishers. 
Higgins, S., Hall, E., Wall, K., Woolner, P., \& McCaughey, C. (2005). The impact of school environments: A literature review. London: The Design Council.

Illich, I. (1975). Deschooling society. London: Calder and Boyers.

Institute for the Future \& Dell Technologies. (2017). The next era of human-machine partnerships. Palo Alto, CA: Institute for the Future.

Kaufer, S., \& Chemero, A. (2015). Phenomenology: An introduction. Cambridge: Polity Press.

Kennedy, I. G., Latham, G., \& Jacinto, H. (2016). Education skills for 21 st century teachers: Voices from a global online educators' forum. Cham, Switzerland: Springer. http://doi.org/10.1007/9783-319-22608-8

Kereluik, K., Mishra, P., Fahnoe, C., \& Terry, L. (2013). What knowledge is of most worth. Journal of Digital Learning in Teacher Education, 29(4), 127-140. http://doi.org/10.1080/21532974.2013 .10784716

Kihlstrom, J. F. (2013). The person-situation interaction. In The Oxford handbook of social cognition (pp. 786-805). New York: Oxford University Press.

Klawonn, I. M. (2010). A building that suits the vision. In Mind your behaviour. How architecture shapes behaviour. Copenhagen: 3XN, Dansk Architecture Center.

Le Corbusier. (1986). Towards a new architecture. Mineola, NY: Dover Publications. Le Corbusier. (1987). The city of tomorrow and its planning. New York: Courier Corporation.

Lewin, K. (1936). Principles of topological psychology. New York: McGraw-Hill. Lynch, K. (1960). The Image of the City. Cambridge, MA: MIT Press.

Mishra, P., \& Mehta, R. (2017). What we educators get wrong about 21st-century learning:

Results of a survey. Journal of Digital Learning in Teacher Education, 33(1), 6-19. http://doi.org/1 $0.1080 / 21532974.2016 .1242392$

Moore, M. G. (1989). Editorial: Three types of interaction. American Journal of Distance Education, 3(2), 1-7. http://doi.org/10.1080/08923648909526659

National Advisory Committee on Creative and Cultural Education (NACCCE). (1999). All our futures: Creativity, culture and education. London: Department for Education and Employment. Norman, D. A. (2013). The design of everyday things: Revised and expanded edition. New York: Basic Books. 
Partnership for 21st Century Learning (P21). (2017a). 21st century learning for early childhood: Guide. Retrieved from http://www.p21.org/storage/documents/EarlyLearning_Framework/P21_ ELF_Guide_Fi nal.pdf

Partnership for 21 st Century Learning (P21). (2017b). 21 st century skills. Early learning: Framework (Vol. 7563). Retrieved from http://www.p21.org/storage/documents/EarlyLearning_Framework/ P21_ELF_Framewor k_Final.pdf

Piirto, J. (2011). Creativity for 21st century skills. Rotterdam: SensePublishers. Prensky, M. (2001). Digital natives, digital immigrants. On the Horizon, 9(5), 1-6.

http://doi.org/10.1108/10748120110424816

Rasmussen, S. E. (1962). Experiencing architecture. Cambridge, MA: MIT Press. Robinson, K. (2010). Changing education paradigms. [Video file]. Retrieved from https://www.ted.com/talks/ ken_robinson_changing_education_paradigms

Sanoff, H. (2001). School building assessment methods. Washington, DC: National Clearinghouse for Educational Facilities.

Strange, C. C., \& Banning, J. H. (2001). Educating by design: creating campus learning environments that work. San Francisco: Jossey-Bass.

Tillas, A., Vosgerau, G., Seuchter, T., \& Caiani, S. Z. (2017). Can affordances explain behavior? Review of Philosophy and Psychology, 8(2), 295-315. http://doi.org/10.1007/s13164-016-0310-7

Van Den Driessche, M. (2007). The journey of children.... OASE: Journal for Architecture, 72, 72-97. Retrieved from https://www.oasejournal.nl/en/Issues/72/TheJourneyOfChildren\#072

von Moos, S. (2009). Le Corbusier: Elements of a synthesis. Rotterdam: 010 Publishers. http://doi. org/10.1080/00220272.2012.668938

Voogt, J., \& Pareja Roblin, N. (2012). A comparative analysis of international frameworks for 21st century competences: Implications for national curriculum policies. Journal of Curriculum Studies, 44(3), 299-321.

Walden, R. (2009). Criteria for the judgment of the quality of school buildings. In R. Walden (Ed.), Schools for the future. Design proposals from architectural psychology (pp. 169- 187). Boston, MA: Hogrefe Publishing.

Weinstein, C. S. (1979). The physical environment of the school: A review of the research. Review of Educational Research, 49(4), 577-610. http://doi.org/10.3102/00346543049004577 
Withagen, R. (2018). Towards an ecological approach to emotions and the individual differences therein. New Ideas in Psychology, 51, 21-26. http://doi.org/10.1016/j.newideapsych.2018.04.004

Withagen, R., Araújo, D., \& de Poel, H. J. (2017). Inviting affordances and agency. New Ideas in Psychology, 45, 11-18. http://doi.org/10.1016/j.newideapsych.2016.12.002 Withagen, R., de Poel, H. J., Araújo, D., \& Pepping, G.-J. (2012). Affordances can invite

behavior: Reconsidering the relationship between affordances and agency. New Ideas in Psychology, 30(2), 250-258. http://doi.org/10.1016/j.newideapsych.2011.12.003

Woolner, P., Hall, E., Higgins, S., McCaughey, C., \& Wall, K. (2007). A sound foundation? What we know about the impact of environments on learning and the implications for Building Schools for the Future. Oxford Review of Education, 33, 47-70. http://doi.org/10.1080/03054980601094693

Wright, P., \& McCarthy, J. (2005). The value of the novel in designing for experience. In A. Pirhonen, P. Saariluoma, H. Isomäki, \& C. Roast (Eds.), Future interaction design (pp. 9-30). London: Springer London.

Zhao, Y. (2014). Who's afraid of the big bad dragon? Why China has the best (and worst) education system in the world. San Francisco: Jossey-Bass. 
International Scientific and Practical Conference

PEDAGOGY AND MODERN EDUCATION

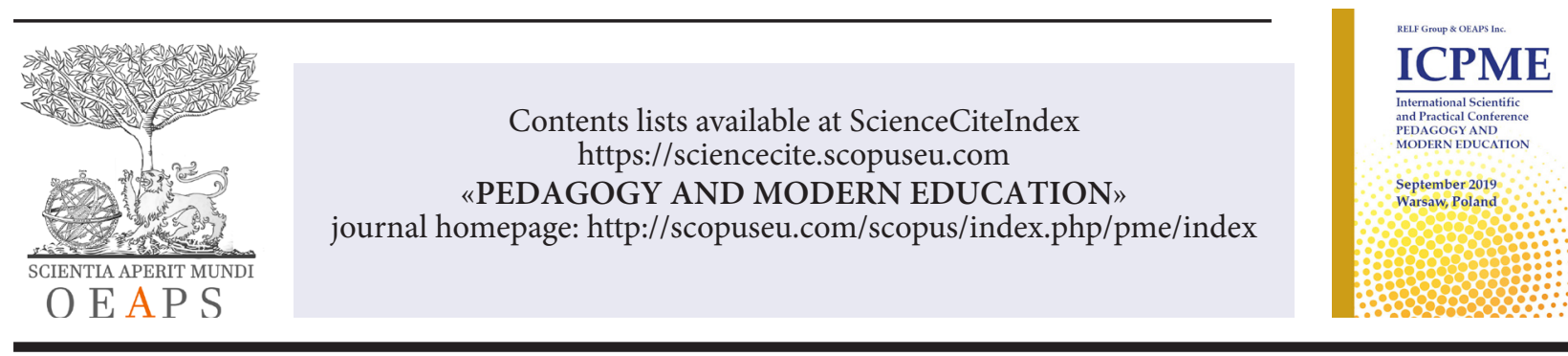

УДК 796

Динамика показателей видов координационных способностей

в процессе их развития средствами карате у детей младшего школьного возраста с нарушением слуха

Дерябина Галина Ивановна кандидат педагогических наук, доиент, заведующий кафедрой безопасности жизнедеятельности и общей физической подготовки,

Федеральное государственное бюджетное образовательное учреждение высшего образования «Тамбовский государственный университет имени Г.Р. Державина», Россия,

Тамбов

dergal@yandex.ru

Савельев Артем Валентинович

кандидат экономических наук, декан факультета физической культуры и спорта, Федеральное государственное бюджетное образовательное учреждение высшего образования «Тамбовский государственный университет имени Г.Р. Державина», Россия, Тамбов tema.save@yandex.ru

Лернер Виктория Леонидовна кандидат педагогических наук, дочент, дочент кафедры физического воспитания и адаптивной физической культуры,

Федеральное государственное бюджетное образовательное учреждение высшего образования «Тамбовский государственный университет имени Г.Р. Державина», Россия,

Тамбов

vikun69@yandex.ru

Макарова Людмила Николаевна доктор педагогических наук, профессор, заведуюший кафедрой педагогики и образовательных технологий,

Федеральное государственное бюджетное образовательное учреждение высшего образования «Тамбовский государственный университет имени Г.Р. Державина», Россия, Тамбов mako20@inbox.ru

(c) 2019 The Author. Published by OEAPS Inc. This is an open access article under the CC BY-NC-ND license (http://creativecommons.org/licenses/by-nc-nd/4.0/) 
«Исследование выполнено при финансовой поддержке РФФИ и Субъекта РФ (Тамбовская область) в рамках научного проекта № 18-413-680003 р_а «Разработка теоретикометодических основ развития координационных способностей у детей с нарушениями слуха средствами карате»

The dynamics of indicators of the types of coordination abilities in the process of their development by means of karate in children of primary school age with hearing impairment

Deryabina Galina Ivanovna Candidate of Pedagogical Sciences, Associate Professor, Head of the Department of Life Safety and General Physical Training, Federal State Budgetary Educational Institution of Higher Education "Tambov State University named after G.R. Derzhavina “, Russia, Tambov

Savelyev Artem Valentinovich PhD in Economics, Dean of the Faculty of Physical Culture and Sports, Federal State Budgetary Educational Institution of Higher Education "Tambov State University named after G.R. Derzhavina “, Russia, Tambov

Lerner Victoria Leonidovna

Candidate of Pedagogical Sciences, Associate Professor, Associate Professor of the Department of Physical Education and Adaptive Physical Culture, Federal State Budgetary Educational Institution of Higher Education "Tambov State University named after G.R. Derzhavina ", Russia, Tambov

Makarova Lyudmila Nikolaevna Doctor of Pedagogical Sciences, Professor, Head of the Department of Pedagogy and Educational Technologies,

Federal State Budgetary Educational Institution of Higher Education "Tambov State University named after G.R. Derzhavina “, Russia, Tambov

The study was carried out with the financial support of the Russian Federal Property Fund and the Subject of the Russian Federation (Tambov Region) within the framework of the scientific project No. 18-413-680003 r_a «Development of theoretical and methodological foundations for the development of coordination abilities in children with hearing impairment using karate» 
Аннотация: B данной публикации представлена динамика показателей видов координационных способностей в процессе их направленного развития средствами карате у детей младшего школьного возраста с нарушением слуха.

Ключевые слова: координационные способности, виды координационных способностей, дети младшего школьного возраста с нарушением слуха

Annotation: This publication presents the dynamics of indicators of the types of coordination abilities in the process of their directed development by means of karate in children of primary school age with hearing impairment.

Key words: coordination abilities, types of coordination abilities, children of primary school age with hearing impairment

Проблемы инвалидизации населения, улучшение условий жизни инвалидов, как одной из самых социально уязвимых категорий, их адаптация и интеграция в общество входят в число приоритетных государственных задач, не только в России, но и в большинстве стран мира. Данной проблеме посвящен ряд исследований, разработаны различные методики физкультурно-оздоровительной работы с различными нозологическими группами, с учетом их двигательных и психических особенностей.

У глухих детей потеря слуха приводит к нарушению развития всех сторон речи, а в ряде случаев к полному ее отсутствию, что ограничивает возможности мышления, отражается на особенностях поведения - замкнутость, нежелание вступать в контакт. Потеря слуха часто сопровождается поражением вестибулярного аппарата, что негативно отражается на двигательной сфере ребенка. Характерными проявлениями является нарушение статистического и динамического равновесия, точности движений, пространственной ориентировки, способности усваивать заданный ритм движений, то есть практически видов координационных способностей.

Современные методы и подходы к диагностике и коррекции координационных способностей детей с ограниченными возможностями здоровья зачастую не учитывают их нозологические особенности и смещенные сензитивные периоды развития их двигательных способностей. Развитие координационных способностей у детей с нарушением слуха является жизненно важной составляющей единого процесса их социальной адаптации, и положено в основу формирования арсенала новых двигательных умений и навыков.

Поскольку координационные способности представляют собой совокупность множества освоенных двигательных координаций, обеспечивающих продуктивную двигательную деятельность, и являются весьма сложными по своей структуре и содержанию, современный подход к их развитию требует применения целого комплекса методик и приемов в рамках общего образовательного и воспитательного процесса. 
В рамках данного исследования мы отслеживали динамику видов координационных способностей у детей с нарушениями слуха в процессе их направленного развития средствами карате, так как карате как вид спорта обладает широким арсеналом средств воспитания способностей данного вида, а также является популярным видом спортивной деятельности для детей любого возраста, не требует значительных материальных затрат для организации и проведения занятий, положительно влияет на формирование социально значимых психологических свойств личности. Авторами данной публикации разработана методика развития видов координационных способностей средствами карате у детей с нарушением слуха, внедренная в процесс адаптивного физического воспитания специального коррекционного образовательного учреждения. [1, с.387].

Мы предложили исследовать координационные способности по следующим видам, охватывающим основной спектр проявления координации: способность к произвольному и рациональному снижению напряжения мышц, способность к равновесию, способность к быстрому реагированию, способность к усвоению метро-ритмических связей, способность к согласованию движений тела и его частей, способность к тонкой мышечной координации, способность к пространственной ориентации, способность к дифференцированию кинетических, динамических и пространственных параметров движения [1, с.388].

Для развития каждого из представленных видов координационных способностей нами были разработаны средства карате. К примеру для развития способности к произвольному и рациональному снижению мышечного напряжения мы определили упражнения карате, связанные с техникой «кихон», предполагающая отработку ударов и блоков в движении и в статике (правильность выполнения упражнений зависит от степени произвольности расслабления тела и его звеньев и напряжений, обеспечивающих четкость движений, техничность и скорость): чоки-цуки, хатиджи-дачи и многократное выполнение ката.

Данная методика была апробирована нами на протяжении 9 месяцев в экспериментальной группе занимающихся специального коррекционного образовательного учреждения. Для осуществления сравнительного анализа развития видов координационных способностей мы изучали их динамику и в контрольной группе, занятия в которой проводились по обычно программе адаптивного физического воспитания специального коррекционного образовательного учреждения и были дополнены спортивными и подвижными играми. При этом, поддержание системности в развитии видов координационных способностей не осуществлялось.

Эффективность воздействия средств разработанной нами методики мы отслеживали в ходе выявления динамики изменения видов координационных способностей в контрольной и экспериментальной группах (таблица 1, рисунки 1-8) с помощью следующих тестов: способность к произвольному расслаблению (определение мышечного расслабления в сочетании с гибкостью по методу А.А. Артеменкова, Н.И. Сапожникова), динамического равновесия (повороты на гимнастической скамейке, П. Хиртц), способность к проявлению 
точности мелкой моторики (кулак-ребро-ладонь, Н.И. Озерецкий), способность к усвоению двигательного ритма (спринт в заданном ритме, П. Хиртц), способность к согласованию движений тела и его частей в составе двигательного действия (перешагивание через гимнастическую палку, В.И. Лях), способность к ориентированию в пространстве (прыжки к цели, П. Хиртц), способность к дифференцированию усилий, времени, пространства (прыжок вниз на разметку, П. Хиртца), способность к проявлению быстроты реагирования (отпускание палки - реакция, В.Ф. Ломейко, К. Мекота) [1, с.2].

Оценка по данным тестам нами осуществлялась в ноябре 2018 г., феврале, мае и августе 2019 года в контрольной и экспериментальной группах (ЭГ и КГ). Для обеспечения большей наглядности мы представили результаты данных тестирований в виде диаграмм (рисунки $1-8)$.

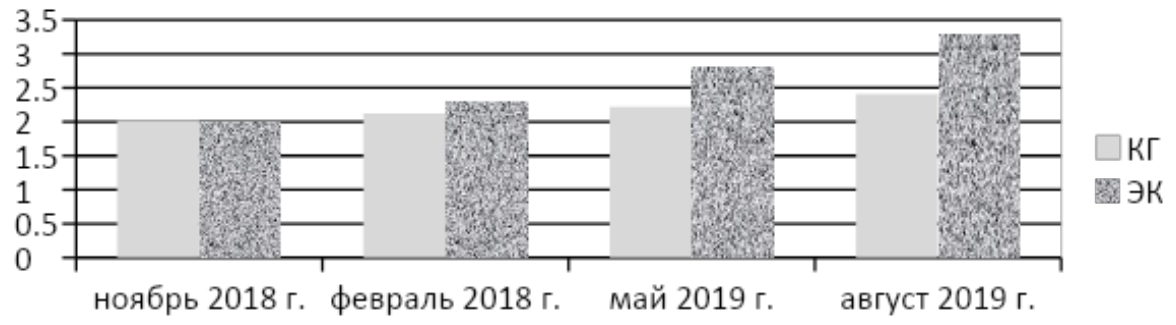

Рисунок 1 - Динамика результатов тестирования показателя способности к произвольному расслаблению (балл)

На рисунке 1 представлена динамика результатов тестирования показателя способности к произвольному расслаблению, определяемого в баллах по пятибалльной шкале. Столбики диаграммы показывают наибольшие приросты данного показателя в экспериментальной группе. При этом абсолютные показатели данной способности все-таки достаточно далеки от максимально возможных, что является одной из особенностей данной патологии.

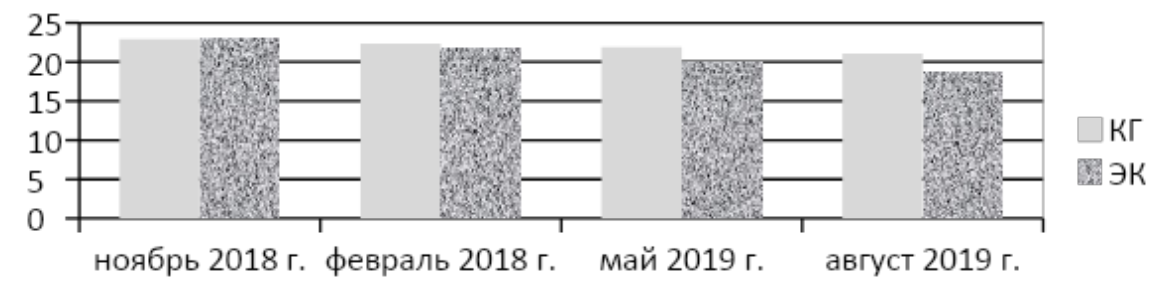

Рисунок 2 - Динамика результатов тестирования показателя способности к равновесию (с) Динамика данного показателя также имеет ярко выраженные положительные тенденции в экспериментальной группе, при начальных практически одинаковых исходных значениях двух групп. 


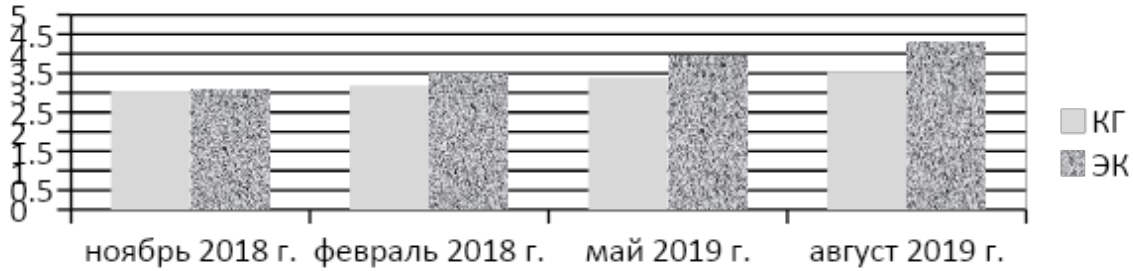

Рисунок 3 - Динамика результатов тестирования показателя способности к проявлению точности тонкой моторики (балл)

Отслеживание результатов проявления точности тонкой моторики показало наибольшие приросты в экспериментальной группе, по сравнению с контрольной и подтверждает эффективность ее развития упражнениями в процессе отработки техники «дьяку-цуки» о стену, выполнении удара «дьяку-цуки» с ловлей мяча от стены, с попаданием по мячу с помощью данного удара и средствами вида спорта карате.

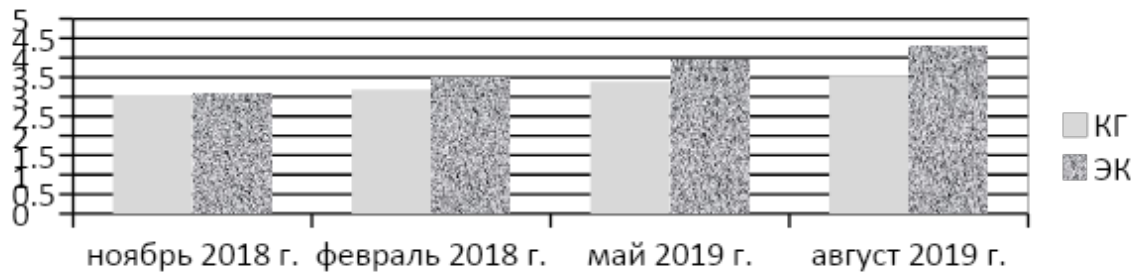

Рисунок 4 - Динамика результатов тестирования показателя темпо-ритмовой способности (c)

Для развития темпо-ритмовой способности нами также были разработаны средства карате, к примеру выполнение ката в соответствии со своей ритмоструктурой (например, ката «тайкиоку шодан» выполняется по ритму «раз - два - пауза, раз - два - пауза» и другими, что обеспечило большие приросты данного показателя в экспериментальной группе. При этом в контрольной группе данный показатель практически не получил направленного развития, что отразилось на результатах контрольной группы.

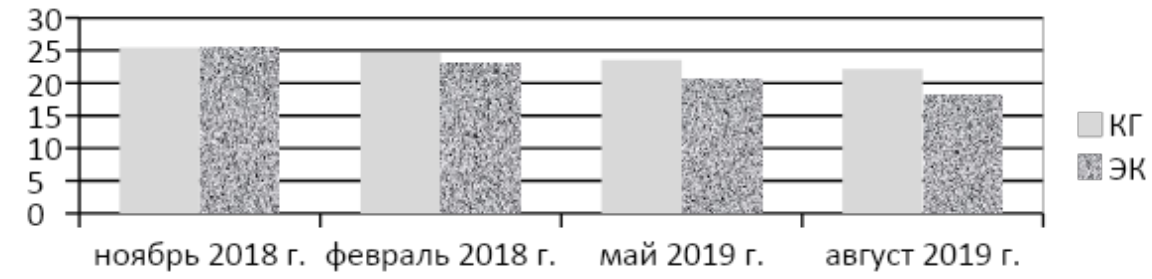

Рисунок 5 - Динамика результатов тестирования показателя способности к ориентированию в пространстве (c) 
Ориентирование в пространстве как координационная способность является жизненно важной для детей со слуховой депривацией. Учитывая смещенные сензитивные периоды ее естественного формирования у глухих и слабослышащих ее развитию следует уделять повышенное внимание. В данном исследовании мы решали эту задачу, выполняя упражнения на краю татами - уходы от атаки в рамках татами (достигается осознание его границ) и рядом других упражнений, что отразилось в более эффективном развитии данной способности в экспериментальной группе.

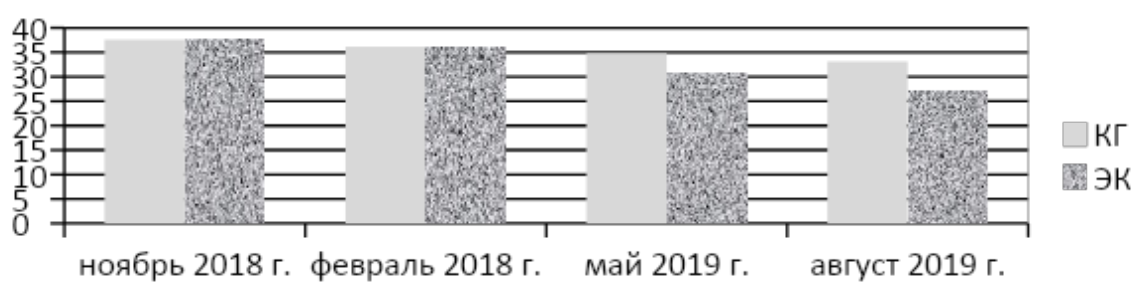

Рисунок 6 - Динамика результатов тестирования показателя способности к согласованию движений в составе двигательного действия (c)

Динамика показателя способности к согласованию движений в составе двигательного действия выявлена более значительной опять же в экспериментальной группе, что подтверждает эффективность направленного воздействия средств караете на конкретный вид координационных способностей с одной стороны, и результативность их развития в совокупности.

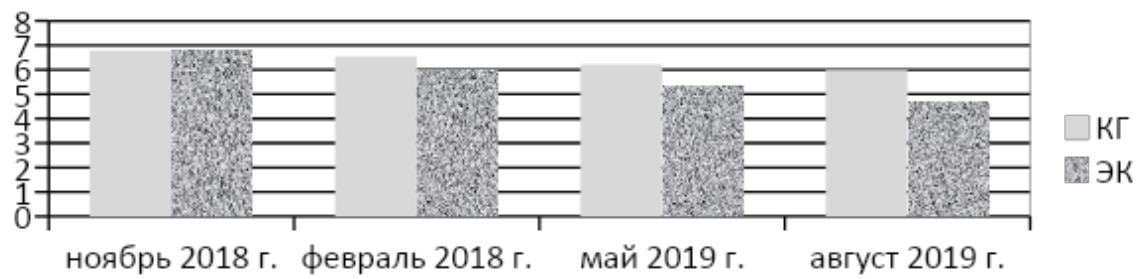

Рисунок 7 - Динамика результатов тестирования показателя способности к дифференцированию усилий времени и пространства (см)

Способность к дифференцированию усилий, времени, пространства как способности, отражающей точность оценивания, отмеривания и воспроизведения заданных параметров движения в нашем исследовании мы развивали с помощью различных «ката» различающихся по ритму, скорости, технике ударов и блоков (например «тайкиоку шодан» и «хиан нидан»), что показало свою эффективность, проявленную в более выраженной положительной динамике этого показателя у детей экспериментальной группы. 


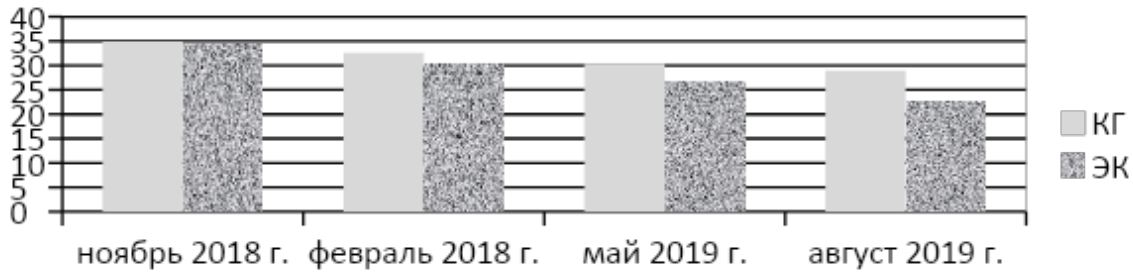

Рисунок 8 - Динамика результатов тестирования показателя способности к быстроте реагирования (см)

Быстрота реагирования у детей младшего школьного возраста с нарушением слуха, как и вышеперечисленные виды координационных способностей, также была отмечена более выразительной динамикой в экспериментальной группе.

Таким образом, нами получена в целом положительная динамика показателей видов координационных способностей в ходе направленного развития каждого из видов средствами карате в экспериментальной группе, значительно отличающаяся от результатов контрольной группы.

Вышеизложенное позволяет резюмировать, что средства вида спорта карате действительно являются эффективным фактором в развитии всех компонентов (видов) координационных способностей у детей со слуховой патологией и могут быть рекомендованы для широкого практического применения.

Список литературы:

1. Староста В., Хиртц П., Павлова-Староста Т. Сенситивные и критические периоды в развитии двигательных координационных способностей у юных спортсменов // Физическая культура, воспитание, образование, тренировка. 2009. № 2. С. 2-3.

2. Филаткин А.С., Савельев А.В., Дерябина Г.И. Возможности развития видов координационных способностей средствами карате у детей младшего школьного возраста с нарушением слуха. В сборнике: Перспективы развития студенческого спорта и Олимпизма. Сборник статей Всероссийской с международным участием научно-практической конференции студентов. Под редакцией О.Н. Савинковой, А.В. Ежовой. Воронеж, 2019. С. 387-395. 


\section{The text of the article in English}

Disability issues, improving the living conditions of people with disabilities, as one of the most socially vulnerable categories, their adaptation and integration into society are among the state priority tasks that are not only in Russia, but also in most countries of the world. A number of studies are devoted to this problem; various methods of physical-health-improving work with various nosological groups have been developed, taking into account their motor and mental characteristics.

In deaf children, hearing loss leads to impaired development of all aspects of speech, and in some cases to its complete absence, which limits the ability of thinking, affects the features of behavior - isolation, unwillingness to make contact. Hearing loss is often accompanied by damage to the vestibular apparatus, which negatively affects the motor sphere of the child. Characteristic manifestations are a violation of statistical and dynamic equilibrium, accuracy of movements, spatial orientation, ability to assimilate a given rhythm of movements, that is, practically types of coordination abilities.

Modern methods and approaches to the diagnosis and correction of coordination abilities of children with disabilities often do not take into account their nosological characteristics and shifted sensitive periods of development of their motor abilities. The development of coordination abilities in children with hearing impairment is a vital component of a single process of their social adaptation, and laid the foundation for the formation of an arsenal of new motor skills.

Since coordination abilities are a combination of many mastered motor coordination, providing productive motor activity, and are very complex in structure and content, a modern approach to their development requires the application of a whole range of techniques and techniques within the framework of the general educational and educational process.

In the framework of this study, we tracked the dynamics of the types of coordination abilities in children with hearing impairments in the process of their directed development with karate, since karate as a sport has a wide arsenal of means of educating the abilities of this type, and is also a popular sport activity for children of any age, does not require significant material costs for the organization and conduct of classes, positively affects the formation of socially significant psychological properties of the individual. The authors of this publication have developed a methodology for developing types of coordination abilities with karate in children with hearing impairment, which has been introduced into the process of adaptive physical education of a special correctional educational institution. [1, p. 387].

We proposed to study the coordination abilities in the following types, covering the main spectrum of manifestations of coordination: with theability to voluntarily and rationally reduce muscle tension, the ability to balance, the ability to respond quickly, the ability to assimilate metro-rhythmic connections, the ability to coordinate the movements of the body and its parts, the ability to fine 
muscle coordination, the ability to spatial orientation, the ability to differentiate kinetic, dynamic and spatial pairs ters motion [1, s.388].

For the development of each of the presented types of coordination abilities, we have developed karate. For example, todevelop the ability to voluntarily and rationally reduce muscle tension, we identified karate exercises associated with the Kihon technique, which involves practicing strokes and blocks in motion and in static (the correctness of the exercises depends on the degree of randomness of relaxation of the body and its links and stresses, providing clarity of movement, technicality and speed): choki-tsuki, khatiji-dachi and repeated performance of kata.

We have tested this technique for 9 months in an experimental group engaged in a special correctional educational institution. To carry out a comparative analysis of the development of types of coordination abilities, we also studied their dynamics in the control group, classes in which were usually carried out according to the program of adaptive physical education of a special correctional educational institution and were supplemented by sports and outdoor games. At the same time, the maintenance of consistency in the development of types of coordination abilities was not carried out.

We monitored the effectiveness of the methods developed by us in identifying the dynamics of changes in the types of coordination abilities in the control and experimental groups (table 1, figures 1-8) using the following tests: the ability to voluntarily relax (determination of muscle relaxation in combination with flexibility according to method A.A. Artemenkova, NI Sapozhnikova), dynamic balance (turns on the gymnastic bench, P. Hirtz), the ability to exhibit precision fine motor skills (fist-rib-palm, N.I. Oze etsky), ability to assimilate locomotor rhythm (sprint in a predetermined rhythm, P. Hirtts), the ability to harmonize the body movement and its parts in the composition of motor actions (pereshagivaniya through gymnastic stick Lyakh VI), the ability to orient in space (etc.yzhki to the goal, P. Hirtts), the ability to differentiation of effort, time and space(jumpdown on the layout, P. Hirttsa), the ability to exercise the response speed (releasing sticks - reaction, VF Lomeyko, K. Mekota) [1, p.2].

We evaluated these tests in November 2018, February, May and August 2019 in the control and experimental groups (EG and CG). To ensure greater visibility, we presented the results of these tests in the form of diagrams (Figures 1-8).

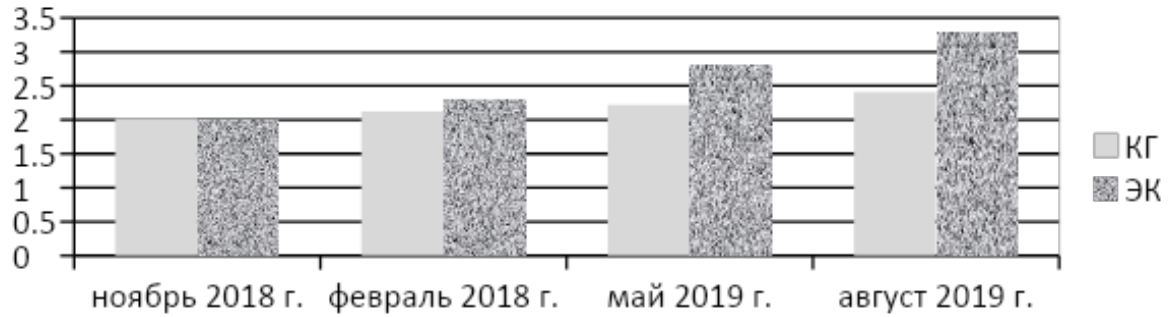

Figure 1 - Dynamics of the results of testing the index of ability to arbitrary relaxation (score) 
Figure 1 presents the dynamics of the results of testing the indicator of ability to arbitrary relaxation, defined in points on a five-point scale. The columns of the diagram show the largest gains of this indicator in the experimental group. Moreover, the absolute indicators of this ability are still quite far from the maximum possible, which is one of the features of this pathology.

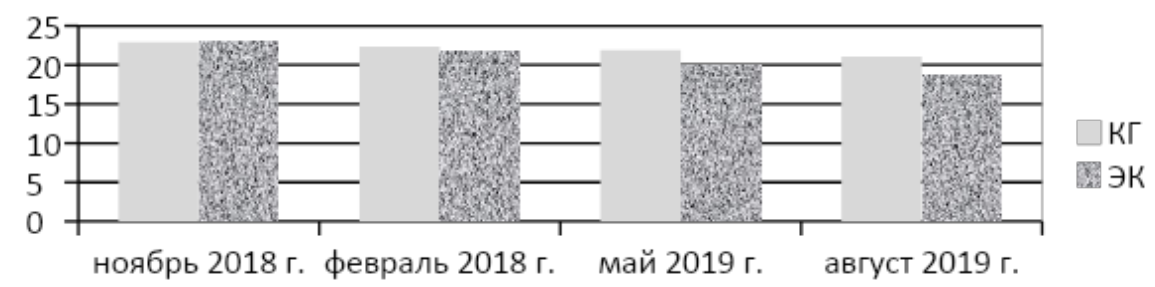

Figure 2 - Dynamics of the results of testing the indicator of the ability to balance (c) The dynamics of this indicator also has pronounced positive trends in the experimental group, with initial almost identical initial values of the two groups.

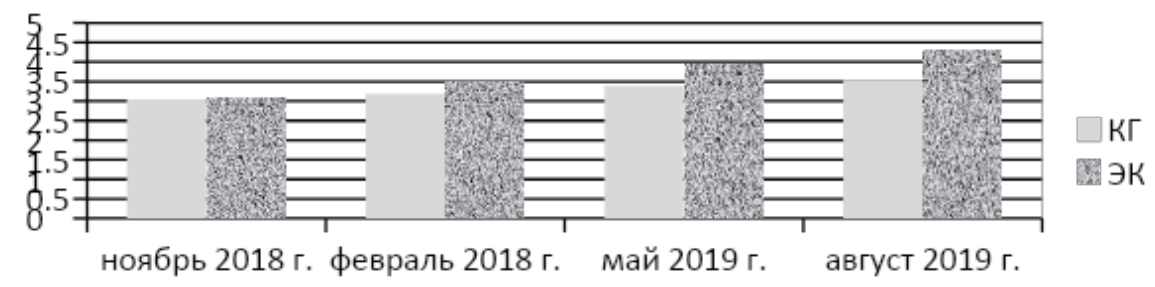

Figure 3 - Dynamics of the results of testing the indicator of the ability to exhibit fine motor skills accuracy (score)

Tracking the results of the manifestation of fine motor skills accuracy showed the greatest gains in the experimental group compared to the control group and confirms the effectiveness of its development by exercises in the process of developing the "clerk-tsuki" technique on the wall performing a strike of a "clerk-tsuki" with catching the ball from the wall, hitting the ball with the help of this blow and means of karate sport.

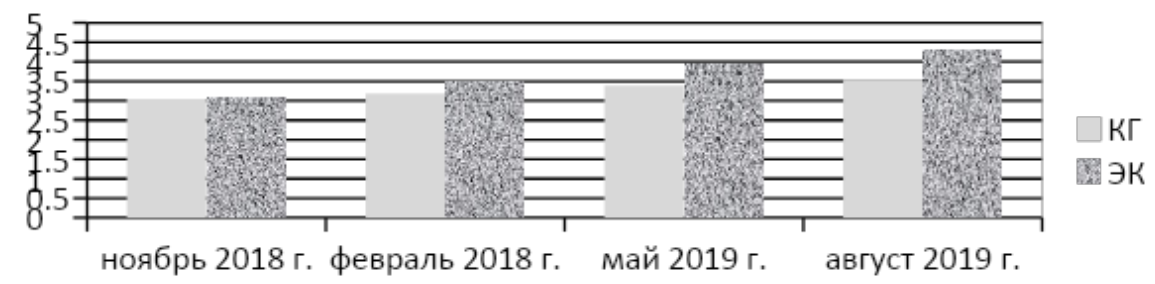

Figure 4 - Dynamics of the results of testing the rate-rhythm ability indicator (c) 
To develop the tempo-rhythm ability, we also developed karate tools, for example, performing kata in accordance with its rhythm structure (for example, taiyoku shodan kata is performed according to the "once - two - pause, one - two - pause "and others, which ensured large increases of this indicator in the experimental group. Moreover, in the control group this indicator practically did not receive directional development, which affected the cut control group tatah-.

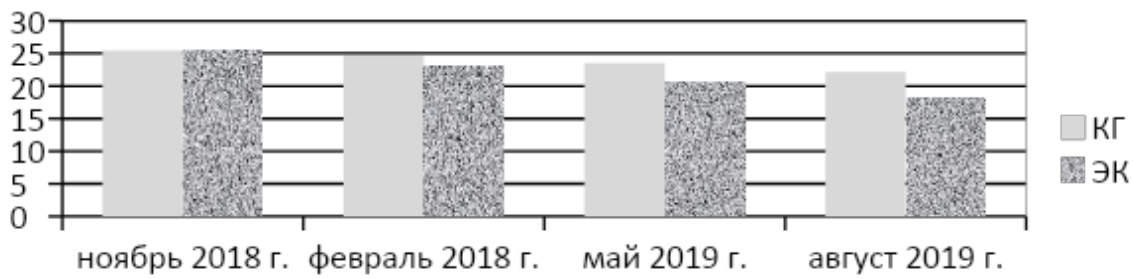

Figure 5 The dynamics of the test results the indicator's ability to orient in space (s)

orientation in space as the coordination capacity is vital for children with auditory deprivation Considering offset sensitive periods of its natural formation of the deaf and hard of hearing to its development should be given high. Attention: In this study, we solved this problem by performing exercises on the edge of the tatami - avoiding the attack within the tatami (achieving awareness of its pages) and a number of other exercises, which was reflected in the more effective development of this ability in the experimental group.

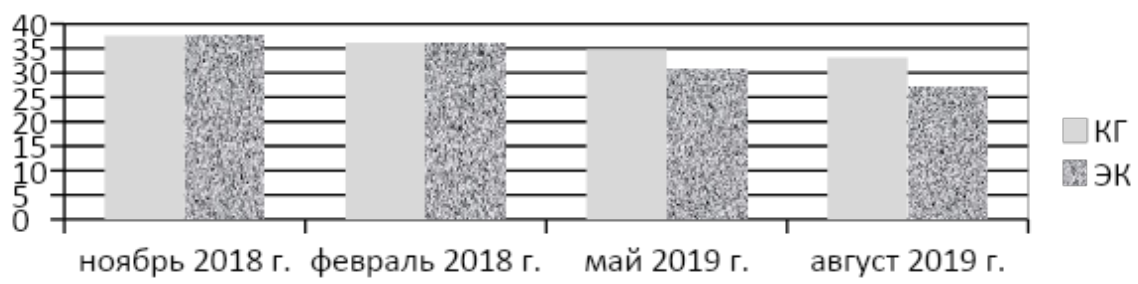

Figure 6 - Dynamics of the results of testing the indicator of ability to coordinate movements in the composition of the motor action (c) The

dynamics of the indicator of the ability to coordinate movements in the composition of the motor action was found to be more significant again in the experimental group, which confirms the effectiveness of the directed action of karaite on a specific type of coordination abilities with on the one hand, and the effectiveness of their development in the aggregate. 


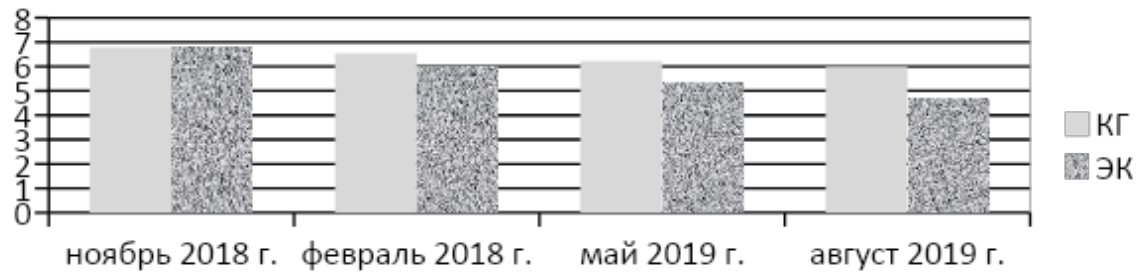

Figure 7 - The dynamics of the results of testing the indicator of the ability to differentiate efforts of time and space $(\mathrm{cm})$

The ability to differentiate efforts, time, space as a ability that reflects the accuracy of estimating, measuring and reproducing given motion parameters in our study, we developed using different "kata" differing according to the rhythm, speed, technique of strikes and blocks (for example, "taiyoku shodan" and "hian nidan"), which has shown its effectiveness, shown in a more pronounced positive din Amike of this indicator in children of the experimental group.

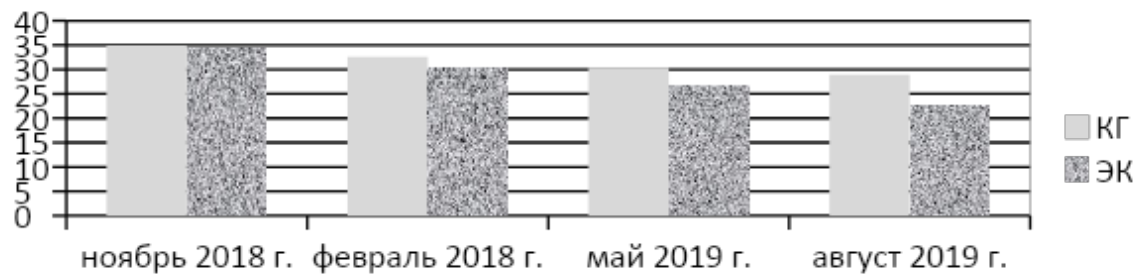

Figure 8 - The dynamics of the results of testing the indicator of the ability to respond quickly (cm) The

speed of response in children of primary school age with hearing impairment, as well as the above types of coordination abilities, was also noted by more expressive dynamics in the experimental group.

Thus, we have obtained a generally positive dynamics of the indices of the types of coordination abilities during the directed development of each of the species by means of karate in the experimental group, which significantly differs from the results of the control group.

The above allows us to conclude that the means of the sport of karate are indeed an effective factor in the development of all components (types) of coordination abilities in children with auditory pathology and can be recommended for wide practical application. 


\section{References}

1. Starosta V., Hirtts P., Pavlova-Starosta T. Sensitive and critical periods in the development of motor coordination abilities in young athletes // Physical Culture, Education, Training. 2009. No. 2. S. 2-3.

2. Filatkin A.S., Savelyev A.V., Deryabin G.I. Opportunities for developing types of coordination abilities with karate in children of primary school age with hearing impairment. In the collection: Prospects for the development of student sports and Olympism. Collection of articles of the AllRussian with international participation of the scientific-practical conference of students. Edited by O.N. Savinkova, A.V. Hedgehog. Voronezh, 2019.S. 387-395. 
International Scientific and Practical Conference

PEDAGOGY AND MODERN EDUCATION

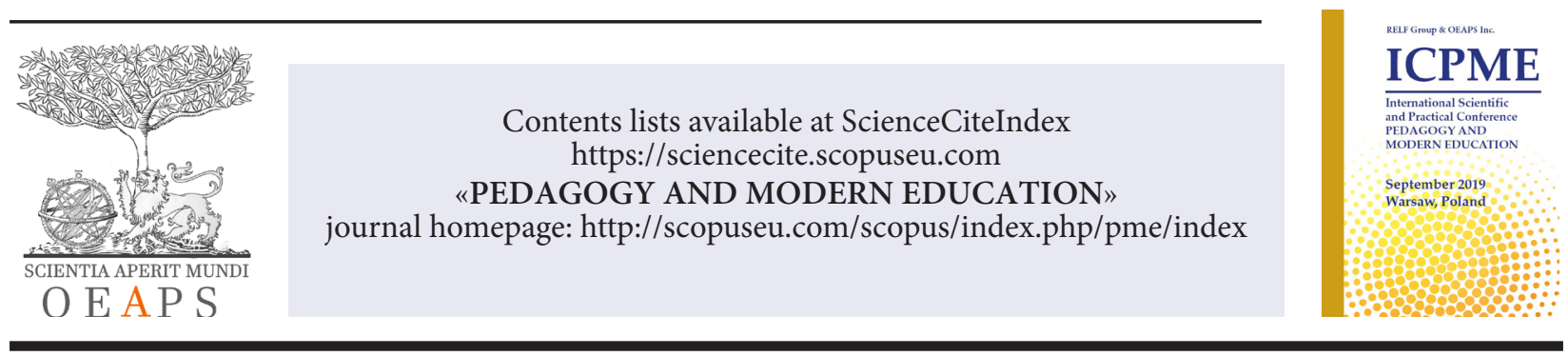

УДК 376.1

\section{Инклюзивное сопровождение и социальная адаптация студентов с нарушениями слуха}

Муллер Ольга Юрьена

Бюджетное учреждение высшего образования Ханты-Мансийского автономного округа-Югры

«Сургутский государственный университет», преподаватель кафедры педагогики профессионального и дополнительного образования, Россия, г. Сургут muller_ou@surgu.ru

\section{Inclusive accompanying and social adaption of hearing-impaired students}

Muller Olga Yurevna

Surgut State University of the Khanty-Mansi

Autonomous Area tutor of Pedagogics of professional and additional education

Russia, Surgut

Аннотация. Статья посвящена вопросам обучения в вузе студентов с нарушениями слуха. Предметом анализа выступают образовательные потребности таких студентов и требования к соответствующей подготовке преподавателей. Автор ставит целью раскрыть организацию процесса инклюзивного обучения в вузе.

Ключевые слова: инклюзивное образование, адаптация, студенты, нарушение слуха, сопровождение.

Abstract. The article focuses on educational issues of hearing-impaired students. The subjects of the analysis are educational needs of these students and the requirements for the level of tuition of tutors. The author's goal is to show the organization of the process of inclusive education in the university. Keywords: inclusive education, adaptation, students, hearing impairments, accompanying.

(c) 2019 The Author. Published by OEAPS Inc. This is an open access article under the CC BY-NC-ND license (http://creativecommons.org/licenses/by-nc-nd/4.0/) 
«Наша миссия, опираясь на неиссякаемую веру в человеческие способности, дать молодежи с ограниченными возможностями здоровья доступ к качественному профессиональному образованию, доступ к успеху».

Сегодня одной из эффективных моделей высшего профессионального образования обучающихся с нарушениями слуха считается инклюзивная форма обучения. Инклюзивное образование активно развивается, однако, профессиональное образование сегодня можно назвать недостаточно развитым звеном в системе высшего образования людей с нарушениями слуха из-за не вполне результативной организации процесса обучения.

Так как глухие и слабослышащие студенты обладают особыми образовательными потребностями, которые предопределены дефектом слуха, в высших учебных заведениях должны быть сформированы специальные образовательные условия, которые гарантируют таким студентам одинаковые возможности в получении высшего профессионального образования по обширному спектру направлений и специальностей, а кроме того, условия для их социальной адаптации и интеграции в социальную инфраструктуру [7, С. 266].

В основу организации процесса инклюзивного обучения положено вариативное по форме инклюзивное обучение обучающихся с нарушениями слуха, которое ориентировано на взаимодействие со слышащими студентами в основных видах деятельности образовательной, познавательной и профессионально-трудовой [1, С. 546].

Специфика психофизиологического развития вызывает у студентов с нарушениями слуха большое число трудностей в овладении знаниями и практическими умениями [1, С. 445]. Поэтому требуется особая организация образовательного процесса, включение новых методов педагогической работы, использование специальных технологий обучения.

Педагогическое сопровождение инклюзивного образования должно быть направлено на овладение студентами специальными компетенциями, которые гарантируют поэтапное складывание у них системы социальных навыков поведения, результативных форм общения с педагогами и студентами [6].

Занятия с такими обучающимися возможны с участием сурдопереводчика, который оказывает помощь в создании диалогового пространства между слабослышащими студентами и преподавателями. И здесь возникают некоторые трудности в силу недостаточной начитанности студентов, сложности научного текста, терминологии, которые сложны для восприятия. Поэтому основная задача сурдопереводчика - максимально точно изложить жестами речь преподавателя, чтобы студент уловил смысл материала и проявил больший интерес к учебе, они тянутся к знаниям. 
В системе образования студентов с нарушениями слуха значимую роль выполняет выбор средств, которые гарантируют результативность образовательного процесса [1, С. 173]. Изза компенсаторной активизации деятельности сохранных органов чувств у таких студентов визуальный канал восприятия информации приобретает главную роль [3].

Одно из важных направлений в процессе образования студентов с нарушениями слуха - применение технических средств обучения. Индивидуализированные компьютерные программы по разным темам и учебным предметам, которые предлагаются студентам с нарушениями слуха, позволяют им получать учебную информацию в наиболее доступном для них варианте [3]. Кроме того, популярно оборудование помещений звукоусиливающей аппаратурой, которая позволяет применять резервы слуха, повышает возможности слухозрительного восприятия устной речи [1, С. 542].

Сегодня в отечественной и зарубежной педагогике с целью осуществления адаптированных образовательных программ большое внимание уделяется разработке технологий высшего профессионального образования студентов с различными нозологиями. Среди педагогических технологий, которые помогают формированию самосознания студентов с проблемами слуха, можно определить личностно-ориентированное обучение, педагогику сотрудничества, технологии групповой работы, диалоговое обучение, творческие и проблемные педагогические технологии, технологию проектирования. Акцент должен быть направлен на интерактивные педагогические технологии, которые подразумевают взаимодействие студентов не только с педагогом, а также и друг с другом: метод «мозгового штурма», деловая игра, круглый стол, проблемное обучение и иное [6]. Интерактивное обучение помогает выполнять параллельно ряд задач, основной из которых выступает развитие коммуникативных умений и навыков. Подобное обучение учит действовать в команде, гарантирует высокую мотивацию, прочность знаний, творчество и фантазию, коммуникабельность, активную жизненную позицию, ценность индивидуальности, формирование жизненных и профессиональных навыков.

Таким образом, с учетом выше сказанного можно отметить, что успешная профессиональная деятельность студентов с нарушениями слуха подразумевает высокий уровень не только обучения и образования, а также и духовно-нравственной, социально-психологической, специальной технологической информации и коммуникативной культуры [7, С. 267].

\section{Список литературы}

1. Андреева Л. В. Сурдопедагогика: учебник / Л. В. Андреева. М.: Академия, 2015. 576 с. 2. Ахметзянова А. И., Артемьева Т. В., Курбанова А. Т. Инклюзивная практика в высшей школе / А. И. Ахметзянова, Т. В. Артемьева, А. Т. Курбанова. Казань: Изд-во Казанского федерального ун-та, 2015. 224 с. 
3. Гулина О. Н., Михайленко, С. А. Специфика организации учебного процесса лиц с ограниченными возможностями здоровья (с проблемами слуха) / О. Н. Гулина, С. А. Михайленко // [Электронный ресурс]. URL: http://www.pk13.ru/ dokument/Methodological\%20 developments/19/19.1..pdf.

4. Муллер О.Ю., Рассказов Ф. Д. Инклюзивное образование в высшей школе: проблемы и решения / О.Ю. Муллер, Ф.Д. Рассказов // Север России : сборник научных трудов / Всерос. научно-практ. конф. (Сургут, 25 мая 2017 г.). Сургут : ИЦ СурГУ, 2017. С. 66-70.

5. Назарова Н. М. Специальная педагогика: уч. пособие / Н. М. Назарова, Л. И. Аксенова, Б. А. Архипов. М.: Академия, 2015. 400 с.

6. Педагогика и психология инклюзивного образования: уч. пособие // Под ред. Д. 3. Ахметова. Казань: Познание, 2013. 204 с.

7. Сурдопедагогика: учебник // Под ред. Е. Г. Речицкой. М.: ВЛАДОС, 2017. 655 с.

\section{The text of the article in English}

"Our mission, relying on an inexhaustible faith in human abilities, to give youth with disabilities access to quality professional education, access to success."

A. G. Stanevsky

Today, one of the most effective models of higher vocational education for students with hearing impairments is considered to be an inclusive form of education. Inclusive education is actively developing, however, professional education today can be called an underdeveloped link in the higher education system of people with hearing impairments due to the not very effective organization of the learning process.

Since deaf and hard of hearing students have special educational needs that are predetermined by a hearing impairment, special educational conditions must be formed in higher education institutions that guarantee such students the same opportunities to receive higher education in a wide range of areas and specialties, and in addition, conditions for their social adaptation and integration into social infrastructure [7, P. 266].

The organization of the inclusive learning process is based on a varied form of inclusive learning for students with hearing impairment, which is focused on interacting with hearing students in the main activities - educational, cognitive and professional labor [1, P. 546].

The specificity of psychophysiological development causes students with hearing impairment a large number of difficulties in mastering knowledge and practical skills [1, P. 445]. Therefore, a special organization of the educational process, the inclusion of new methods of pedagogical work, the use of special teaching technologies are required. 
The pedagogical support of inclusive education should be aimed at mastering students with special competencies that guarantee the gradual development of a system of social skills, effective forms of communication with teachers and students [6].

Classes with such students are possible with the participation of an sign language interpreter, who helps to create a dialogue space between students with hearing impairments and teachers. And here some difficulties arise due to the lack of well-read students, the complexity of the scientific text, terminology, which are difficult to understand. Therefore, the main task of the sign language interpreter is to accurately state with gestures the teacher's speech so that the student grasps the meaning of the material and shows a greater interest in learning, they are drawn to knowledge.

In the educational system of students with hearing impairments, a significant role is played by the choice of means that guarantee the effectiveness of the educational process [1, P. 173]. Due to the compensatory activation of the activity of the sense organs in such students, the visual channel for perceiving information acquires a major role [3].

One of the important directions in the process of education of students with hearing impairments is the use of technical teaching aids. Individualized computer programs on various topics and academic subjects that are offered to students with hearing impairments allow them to receive educational information in the most accessible form for them [3]. In addition, the equipment of premises with sound amplifying equipment, which allows the use of reserves of hearing, increases the possibilities of auditory perception of oral speech [1, P. 542].

Today, in the domestic and foreign pedagogy in order to implement adapted educational programs, much attention is paid to the development of technologies for higher professional education of students with various nosologies. Among the pedagogical technologies that help the formation of self-consciousness of students with hearing problems, one can determine student-centered learning, pedagogy of cooperation, group work technologies, interactive learning, creative and challenging pedagogical technologies, design technology. The emphasis should be on interactive pedagogical technologies, which involve the interaction of students not only with the teacher, but also with each other: the brainstorming method, business game, round table, problem-based learning and more [6]. Interactive learning helps to carry out a number of tasks in parallel, the main of which is the development of communicative skills. Such training teaches us to act in a team, guarantees high motivation, the strength of knowledge, creativity and imagination, sociability, an active life position, the value of individuality, the formation of life and professional skills.

Thus, taking into account the foregoing, it can be noted that the successful professional activity of students with hearing impairments implies a high level of not only training and education, but also spiritual, moral, socio-psychological, special technological information and communicative culture [7, P. 267 ]. 


\section{References}

1. Andreeva L. V. Pedagogy: textbook / L. V. Andreeva. M.: Academy, $2015.576 \mathrm{~s}$.

2. Akhmetzyanova A. I., Artemyeva T. V., Kurbanova A. T. Inclusive practice in higher education / A. I. Akhmetzyanova, T. V. Artemyev, A. T. Kurbanova. Kazan: Publishing House of Kazan Federal University, $2015.224 \mathrm{~s}$.

3. Gulina O. N., Mikhailenko, S. A. Specificity of the organization of the educational process of persons with disabilities (hearing problems) / O. N. Gulina, S. A. Mikhailenko // [Electronic resource]. URL: http://www.pk13.ru/ dokument / Methodological\% 20developments / 19/19.1.. pdf.

4. Muller O.Yu., Rasskazov F. D. Inclusive education in higher education: problems and solutions / O.Yu. Muller, F.D. Narratives // North of Russia: collection of scientific papers / Vseros. scientific and practical. conf. (Surgut, May 25, 2017). Surgut: IC SurGU, 2017.P. 66-70.

5. Nazarova N. M. Special pedagogy: studies. allowance / N.M. Nazarova, L.I. Aksenova, B.A. Arkhipov. M .: Academy, 2015.400 p.

6. Pedagogy and psychology of inclusive education: uch. allowance// Ed. D.Z. Akhmetova. Kazan: Cognition, 2013.204 s.

7. Deaf education: a textbook // Ed. E. G. Rechitskaya. M .: VLADOS, 2017.655 s. 
Contents lists available at ScienceCiteIndex https://sciencecite.scopuseu.com «PEDAGOGY AND MODERN EDUCATION» journal homepage:https://scopuseu.com/scopus/index.php/pme/index 
MINISTERIO DE EDUCACIÓN, CULTURA Y DEPORTE

Subsecretaría

Subdirección General de Cooperación Internacional

Edita: @ SECRETARÍA GENERAL TÉCNICA

Subdirección General de Documentación y Publicaciones

Edición: 2019

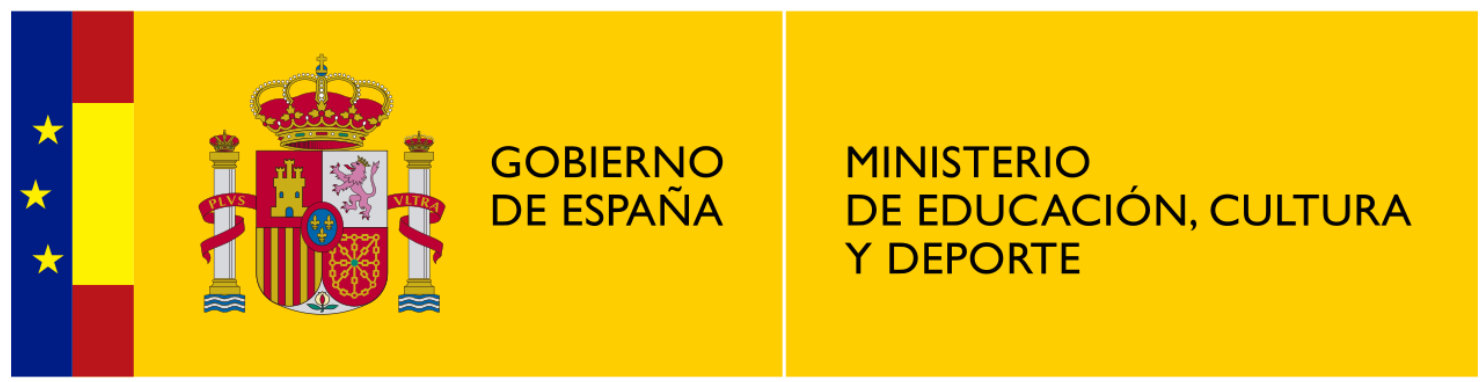

Approved at the meeting of the editorial board

PEDAGOGY AND MODERN EDUCATION (ICPME) September 2019: сб.науч.тр./

RELF Group \& OEAPS Inc.; редкол.: Каапо Кумпулайнен (отв.ред.) [и др.]. - Варшава, Польша : OEAPS Inc., 09. 2019. - 114 C.

Number layout 26.09.2019

Signed in print 28.09..2019

Published on 02.10.2019 



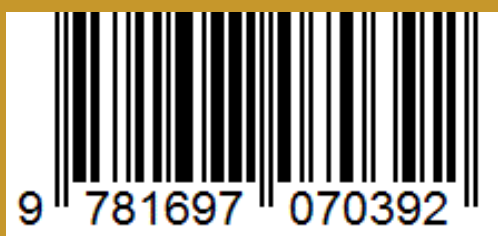

